\title{
The West Virginia Friends of Firewood Network: Engaging with and exploring the practices of firewood producers
}

\author{
Elizabeth Basham \\ West Virginia University
}

Follow this and additional works at: https://researchrepository.wvu.edu/etd

\section{Recommended Citation}

Basham, Elizabeth, "The West Virginia Friends of Firewood Network: Engaging with and exploring the practices of firewood producers" (2013). Graduate Theses, Dissertations, and Problem Reports. 164. https://researchrepository.wvu.edu/etd/164

This Thesis is protected by copyright and/or related rights. It has been brought to you by the The Research Repository @ WVU with permission from the rights-holder(s). You are free to use this Thesis in any way that is permitted by the copyright and related rights legislation that applies to your use. For other uses you must obtain permission from the rights-holder(s) directly, unless additional rights are indicated by a Creative Commons license in the record and/ or on the work itself. This Thesis has been accepted for inclusion in WVU Graduate Theses, Dissertations, and Problem Reports collection by an authorized administrator of The Research Repository @ WVU. For more information, please contact researchrepository@mail.wvu.edu. 


\title{
The West Virginia Friends of Firewood Network: \\ Engaging with and exploring the practices of firewood producers.
}

\author{
Elizabeth Basham
}

Thesis submitted to the

Davis College of Agriculture, Natural Resources, and Design

at West Virginia University

in partial fulfillment of the requirements for the degree of

Master of Science

in

Forestry

\author{
David W. McGill, Ph.D., Chair \\ Ben D. Spong, Ph.D. \\ Kathryn A. Gazal, Ph.D. \\ Division of Forestry
}

\section{Morgantown, West Virginia}

2013

Keywords: firewood, fuelwood, producers, West Virginia

Copyright 2013 Elizabeth Basham 


\title{
ABSTRACT \\ The West Virginia Friends of Firewood Network: Engaging with and exploring the practices of firewood producers.
}

\author{
Elizabeth Basham
}

Firewood is the oldest source of energy for cooking and home heating and remains a primary heating source for half of the world's population, yet the industry remains relatively undocumented and immature both in developing and technologically advanced countries. Firewood is an environmentally friendly and renewable resource that is becoming popular once again in U.S. homes, 2.5 million of which utilize it as a primary heating source. However, firewood is also a proven vector for invasive insects and pathogens that are threatening the health of U.S. forests. In order to address the increasing trend of firewood use and prevent further spread of these invasive species, we need to ensure that firewood producers, who are among the first individuals to lay their hands on this raw wood product, are fully educated and making the right decisions regarding the harvest, transport and sale of firewood. Therefore, the objectives of this project were to create a database of West Virginia firewood producers and conduct a statewide two-part survey in order to learn more about their business, safety and wood hygiene practices. It was found that $51 \%$ have been in business less than five years, and $56 \%$ entered the industry because they had some form of wood residue to dispose of; another $32 \%$ saw the opportunity for supplemental income. Seventy-six percent view firewood production as a hobby, but $50 \%$ are willing to attend classes in order to attain a Community Firewood Dealer certification. The average length of seasoning is 8.4 months and the average delivery radius of respondents is 29.6 miles, although $21 \%$ travel further than 50 miles to deliver. This has implications for the movement of invasive species. 


\section{ACKNOWLEDGEMENTS}

I would like to thank my advisor Dr. Dave McGill and my committee members Dr. Ben Spong and Dr. Kathryn Gazal for their tireless encouragement and feedback.

Thanks to Dr. Stuart Moss for his help with data analyses and organizing my literature review.

Thanks to the Americorps volunteers E. Meade, K. Walker, and P. Baxter who collected phone numbers from the Appalachian Forest Heritage Area, and to the West Virginia Division of Forestry foresters who collected phone numbers on their daily excursions.

I would also like to thank our pilot telephone interview respondents: Paul Ludroski, Bob Driscole and Mike Boyce.

Lastly, I would like to thank my sister and her husband for encouraging me to go back to school for Forestry, and my friends for being so supportive. 


\section{TABLE OF CONTENTS}

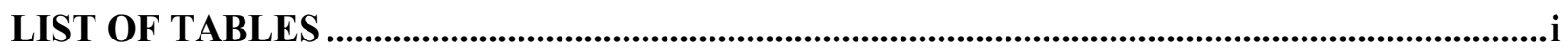

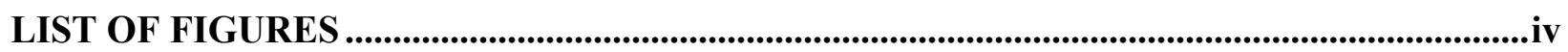

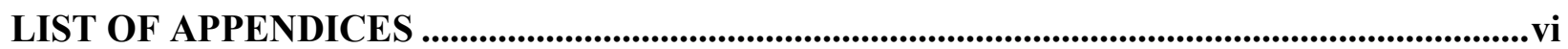

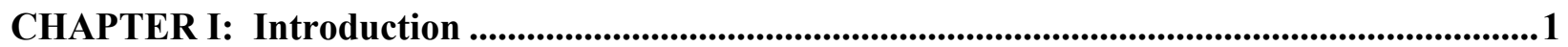

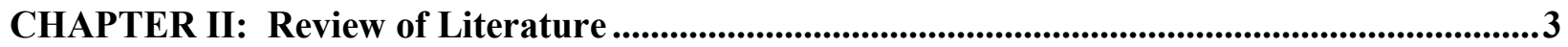

History of fuelwood use in the United States and West Virginia................................................3

Marketing \& Business Practices ................................................................................................................11

Wood Hygiene \& Forest Health ........................................................................................................................... 15

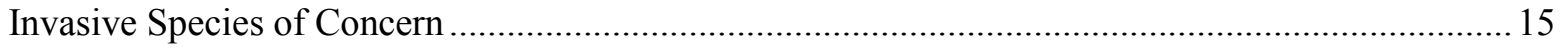

The Role of Firewood in Invasive Species Transport ..................................................................... 18

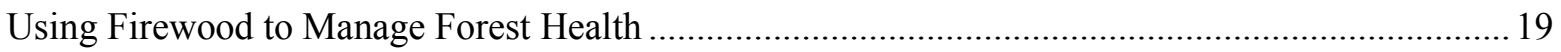

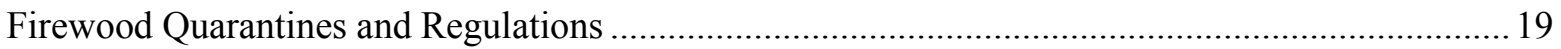

Safety and Personal Protective Equipment Usage ..............................................................21

Best Management Practices .................................................................................................................................24

Objective of Study ....................................................................................................................................26

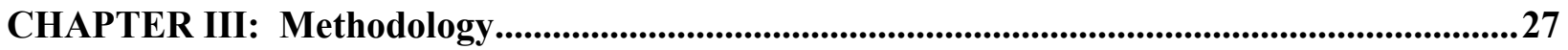

Phase I: Compiling a database of firewood producers (sampling frame) ....................................27

Phase II: Two-part Survey Engagement Strategy …........................................................................28

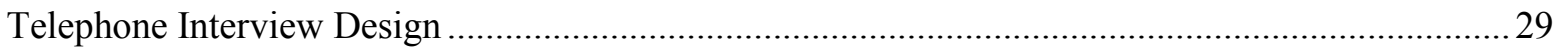

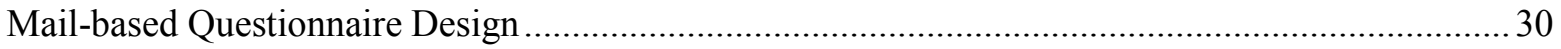

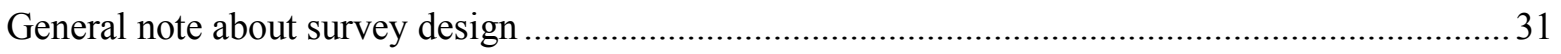

Phase III: Data Manipulation and Analysis ........................................................................................32

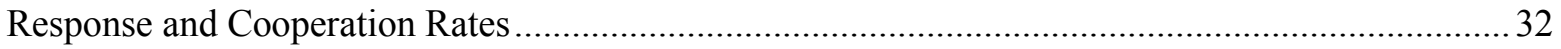

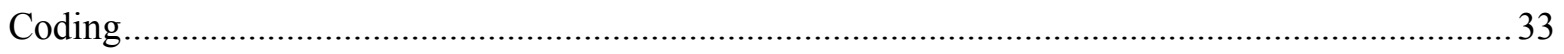

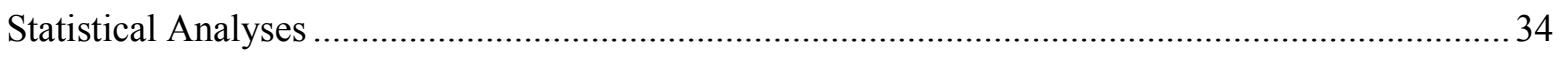

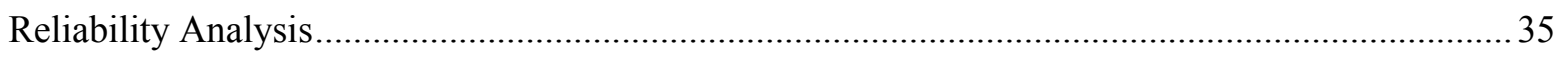

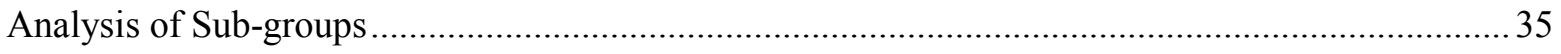

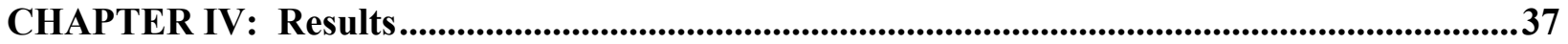

Survey Response and Cooperation Rates .................................................................................................37

Telephone Interview Results ........................................................................................................................38

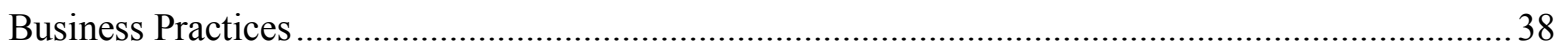

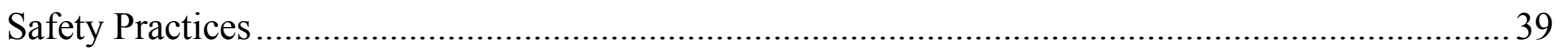




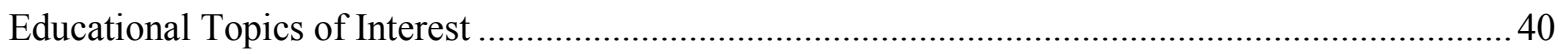

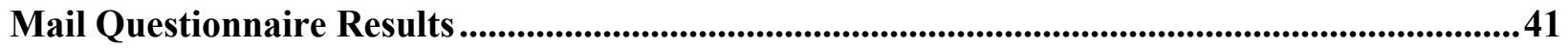

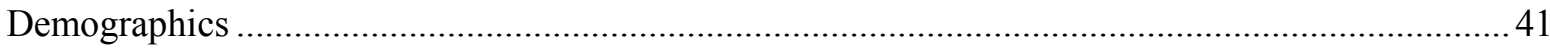

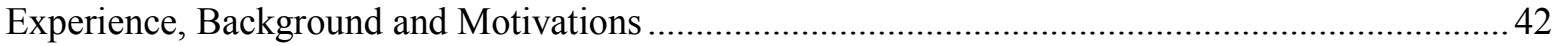

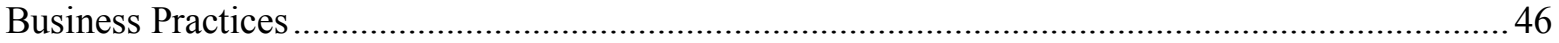

Wood Hygiene and Best Management Practices for Firewood ........................................................52

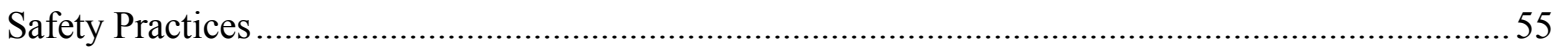

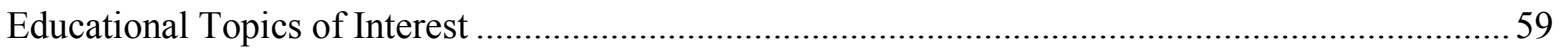

Reliability between Telephone Interview and Mail Questionnaire Responses............................61

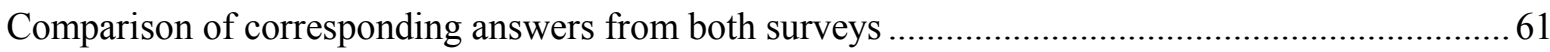

Comparison of telephone interview-only responses to mail questionnaire responses ......................62 62

Analyses of Sub-groups .....................................................................................................................63

Sub-group Willing to Attain Community Firewood Dealer Certification ........................................ 64

Sub-group That Views Firewood Production as a Hobby …............................................................. 64

Sub-group Producing Firewood for Financial Reasons …............................................................. 65

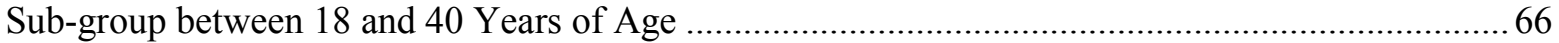

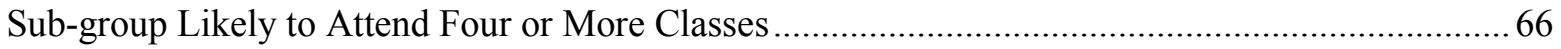

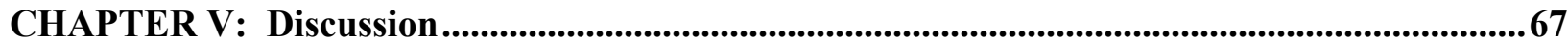

How West Virginia Firewood Producers Compare to Other Producers .........................................67

West Virginia Firewood Producers Who May be willing to Engage in Outreach .......................73

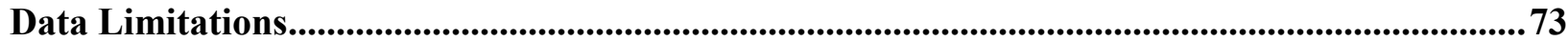

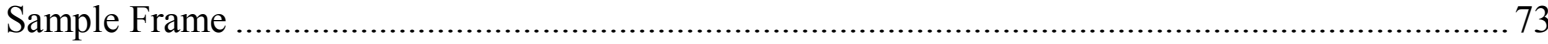

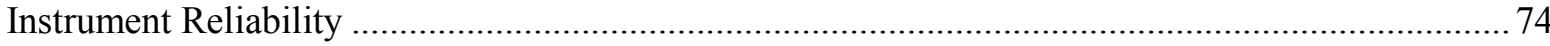

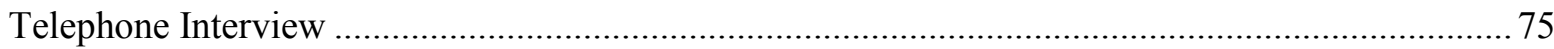

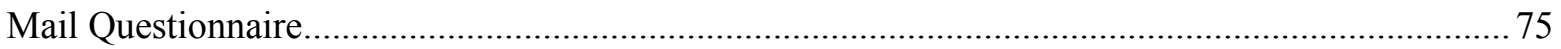

CHAPTER VI: Conclusions, Recommendations and Future Work ...............................................77

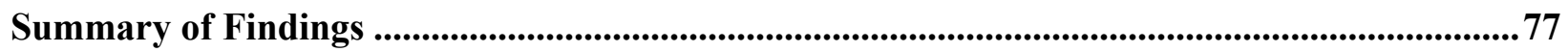

Suggestions for Improving Two-part Survey Design and Future Work .....................................78

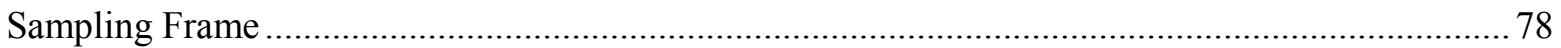

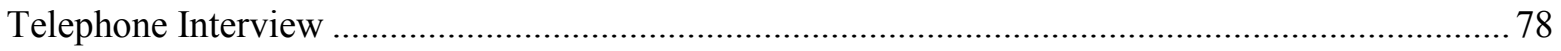

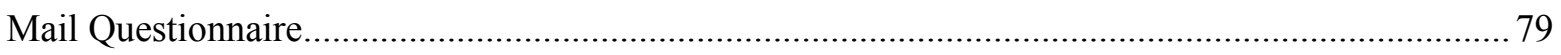

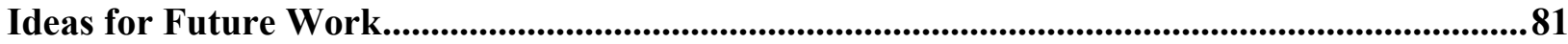

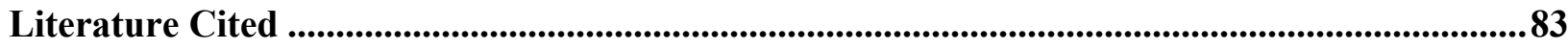

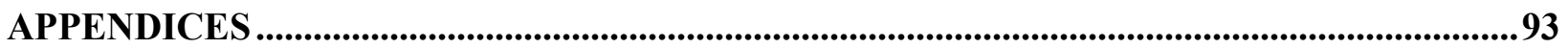




\section{LIST OF TABLES}

Table 1. Thousands of households that use wood for primary home heating during the past six

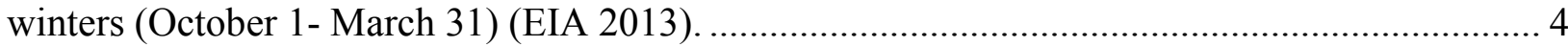

Table 2. Comparison of cost per million BTU of various heating fuels (EIA updated 6/5/13) .... 6

Table 3. Net carbon dioxide emitted by various residential heating fuel systems (MacIntyre 2007)

Table 4. Comparison of BTU content of various species of trees used for firewood and various non-wood heating fuels (NJ DEP undated).

Table 5. Relevant facts on the invasive insects that could be transported in firewood from within and around the state of West Virginia. 17

Table 6. Cost ranges for personal protective equipment apparel available at various retailers. . 22

Table 7. Most common injuries reported by telephone interview respondents. 40

Table 8. Number of years mail questionnaire respondents have been selling firewood, their main employment category, and how they entered the firewood industry. 43

Table 9. Reasons given by mail questionnaire respondents for why they would or would not choose to earn a community firewood dealer certificate. 55

Table 10. Average weekly hours mail questionnaire respondents spend on various business

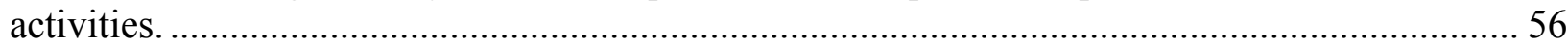

Table 11. Help utilized by mail questionnaire respondents and the safety training offered...... 56

Table 12. Types of PPE used by mail questionnaire respondents and their reasons for not always

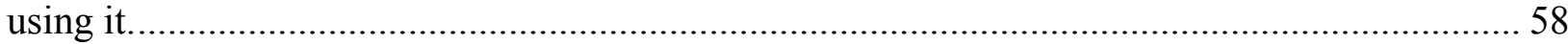

Table 13. Most common injuries reported by mail questionnaire respondents. ....................... 59

Table 14. Response codes from two-part survey used to categorize respondents. ................... 93

Table 15. Number of telephone respondents from various sources. .................................... 93

Table 16. Response rates of individual questions from the mail questionnaire....................... 94

Table 17. Number of mail questionnaire respondents from various sources......................... 95

Table 18. West Virginia and out-of-state counties represented by mail questionnaire respondents.

Table 19. Coding for Question 1 (origin of involvement in the industry) of the mail questionnaire.

Table 20. Coding for Question 18 (delivery charges) of the mail questionnaire.

Table 21. Coding for Question 21 (discounts offered for customer pickup) of the mail questionnaire.

Table 22. Coding for Question 42 (time of day firewood typically produced) of the mail questionnaire. 
Table 23. Coding for Question 5 of the telephone interview and Question 47 of the mail questionnaire (most common injury); these were combined to form two-digit codes. 98

Table 24. Coding for Question 50A-C (description of severe injury experienced within the last 12 months that required more than first aid) from the mail questionnaire. 99

Table 25. Reliability comparison analysis of top three customer types reported by the 41 respondents who participated in both surveys. 100

Table 26. Reliability comparison analysis of corresponding answers concerning delivery radius, percent income earned from firewood, average percent of firewood or customers in West Virginia and average cubic foot volume estimates for pickup trucks used from the 41 respondents who participated in both surveys. T-tests used were paired two-sample for means $(\mathrm{p}<0.1$ significant). 100

Table 27. Reliability comparison analysis of units reported being used by respondents that participated in both surveys $(\mathrm{p}<0.1$ significant).

Table 28. Reliability comparison analysis of class topics that respondents who participated in both surveys would be most likely to attend ( $\mathrm{p}<0.1$ significant). 101

Table 29. Reliability comparison analysis of the most common injuries reported by respondents who participated in both surveys. 102

Table 30. Reliability comparison analysis of the top three customer types reported by telephone interview-only respondents and questionnaire respondents. 102

Table 31. Reliability comparison analysis of telephone interview-only and questionnaire respondents concerning delivery radius, percent income earned from firewood and average percent of firewood sold or customers serviced in West Virginia T-tests used were two-sample assuming unequal variances $(\mathrm{p}<0.1$ significant). 103

Table 32. Reliability comparison analysis of units reported being used by telephone interviewonly respondents and those used by questionnaire respondents. Fisher's Exact Test (FET) results where $\mathrm{p}<0.1$ are considered significant.

Table 33. Reliability comparison analysis of classes that telephone-interview only respondents and questionnaire respondents indicated they would be "somewhat likely" or "very likely" to attend.

Table 34. Reliability comparison analysis of the most common injuries reported by telephone interview-only respondents and questionnaire respondents.

Table 35. Various sub-groups used to compare answers from mail questionnaire respondents using statistical analyses $(\mathrm{p}<0.1$ significant) in order to determine whether certain firewood producers share characteristics that make them more likely to engage in outreach.

Table 36. Continuous variables examined using two-sample t-tests assuming unequal variances $(\mathrm{p}<0.1$ significant) for mail questionnaire respondents, depending on whether or not they are willing to certify. 105

Table 37. Continuous variables examined using two-sample t-tests assuming unequal variances $(\mathrm{p}<0.1$ significant) for mail questionnaire respondents, depending on whether or not they view firewood production as a hobby. 107 
Table 38. Continuous variables examined using two-sample t-tests assuming unequal variances $(p<0.1$ significant) for mail questionnaire respondents, depending on whether or not they are producing firewood for financial reasons.

Table 39. Continuous variables examined using two-sample t-tests assuming unequal variances ( $p<0.1$ significant) for mail questionnaire respondents, depending on whether they are above or below the age of 40 years. 111

Table 40. Continuous variables examined using two-sample t-tests assuming unequal variances ( $p<0.1$ significant) for mail questionnaire respondents, depending on whether or not they have a

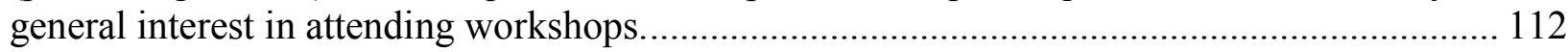

Table 41. A compilation of possible best management practices for West Virginia firewood producers. 


\section{LIST OF FIGURES}

Figure 1. Percent of U.S. households utilizing wood energy for home heating for selected years 1950-2009, (EIA 2013).

Figure 2. Maximum miles telephone respondents are willing to travel to deliver firewood to their customers. 38

Figure 3. Percent of personal individual income earned by telephone interview respondents from selling firewood (93 responses).

Figure 4. Classes that telephone interview respondents are "somewhat likely" or "very likely" to attend.

Figure 5. Percent of mail questionnaire respondents who agree with various statements related to their motivations behind producing firewood, how they feel about their firewood business and the firewood industry's role in maintaining healthy West Virginia forests. 45

Figure 6. Mail questionnaire respondent business categorization. 46

Figure 7. Maximum miles mail questionnaire respondents are willing to travel to harvest raw wood and deliver firewood to customers. 48

Figure 8. Sources of raw wood reported by mail questionnaire respondents. ......................... 48

Figure 9. Size and condition of firewood sold by mail questionnaire respondents. ................... 49

Figure 10. Number of cords sold last year by mail questionnaire respondents $(n=36)$........... 50

Figure 11. Types of ads utilized by mail questionnaire respondents to market their product. ... 50

Figure 12. Percent of personal individual income earned by mail questionnaire respondents from selling firewood.

Figure 13. Number of years mail questionnaire respondents expect to continue producing firewood.

Figure 14. The types of raw wood utilized by mail questionnaire respondents....................... 53

Figure 15. The firewood Best Management Practices with which mail questionnaire respondents would find "somewhat difficult" or "very difficult" to comply.

Figure 16. Time of day that mail questionnaire respondents produce their firewood (39 responses).

Figure 17. Percent of mail questionnaire respondents who are "somewhat likely" or "very likely" to attend various outreach classes.

Figure 18. Maximum distance that mail questionnaire respondents are willing to travel to attend classes.

Figure 19. Classes that mail questionnaire respondents are "somewhat likely" or "very likely" to attend, depending on whether or not they are willing to certify.

Figure 20. Classes that mail questionnaire respondents are "somewhat likely" or "very likely" to attend, depending on whether or not they view firewood production as a hobby. 108 
Figure 21. Advertisement methods utilized by mail questionnaire respondents, depending on whether or not they view firewood production as a hobby..

Figure 22. Advertisement methods utilized by mail questionnaire respondents, depending on whether or not they are producing firewood for financial reasons. .......................................... 110

Figure 23. A visual model of the firewood supply chain in West Virginia based on results from this two-part survey. 


\section{LIST OF APPENDICES}

APPENDIX A: Coding of Survey Results .......................................Error! Bookmark not defined.

Telephone Interview .................................................................................................................... 93

Mail Questionnaire ....................................................................................................................... 94

APPENDIX B: Instrument Reliability Testing Results........................................................ 100

Comparison of corresponding answers from both surveys............................................... 100

Comparison of telephone-only responses to mail questionnaire responses........................ 102

APPENDIX C: Selected Results from Analyses of Sub-groups........................................ 105

Sub-group Willing to Attain Community Firewood Dealer Certification ........................... 105

Sub-group That Views Firewood Production as a Hobby ................................................. 107

Sub-group Producing Firewood for Financial Reasons .................................................. 109

Sub-group between 18 and 40 Years of Age ................................................................ 111

Sub-group Likely to Attend Four or More Classes ......................................................... 112

APPENDIX D: Telephone Interview Script ............................................................................ 113

APPENDIX E: Mail Questionnaire Cover Letter.............................................................. 118

APPENDIX F：Mail Questionnaire ............................................................................ 119

APPENDIX G: Mail Questionnaire Reminder Postcard ................................................. 131

APPENDIX H: Additional Work ............................................................................. 132

Possible Firewood Best Management Practices for West Virginia Producers.................... 132

A Diagram of the West Virginia Firewood Industry Supply Chain ................................... 134 


\section{CHAPTER I: Introduction}

It is estimated that some 30 million households utilize wood energy for heat, making it the most ubiquitous renewable home heating energy source in the United States (Borchert et al. 2010, Jacobi et al. 2012, Alliance for Green Heat 2013). In 1987, wood was the sixth largest supplier of energy in the United States, and the second largest renewable energy source after hydropower (Zerbe \& Skog 1988). Individual households are responsible for most fuelwood consumption, using it for both heating and aesthetic enjoyment (Zerbe \& Skog 1988, Howard \& McKeever 2012).

A disclaimer should be presented here regarding the difficulty in finding exact figures for residential firewood consumption in the U.S., since so many different firewood volume measurements are in employment, and the energy content of these volumes is hard to measure due to variances in moisture content (Marsinko et al. 1984, Wharton 1991, Jacobi 2007, Lindroos 2011). In addition, the number of U.S. homes heating with wood may fluctuate more rapidly than for any other heating fuel because many households with a wood stove have a backup fossil fuel heating system that is used whenever that particular fuel is more affordable (Alliance for Green Heat 2011). It should also be mentioned that many available fuel/firewood figures from government and articles are lumped in with "wood energy" or "wood biomass," terms that also encompass pellets generally, and even chips and wood-derived fuels. "Firewood" or "fuelwood" is defined in this study as, "all wood, split or unsplit less than 4' in length," based on the definition provided by the National Firewood Task Force (7 CFR § 301.92, 2010), and "wood that has been cut, sawn, or chopped into a shape and size commonly used for fuel, or other wood intended for fuel," according to USDA Animal and Plant Health Inspection Service (2010).

The United States experienced a surge in demand for fuelwood after an oil embargo in 1973 raised domestic heating fuel prices considerably (Boguszewski 1983, McKeever et al. 2012). Fuelwood consumption reached its peak in the mid-1980s and thereafter began to decline until 1999, when it began to stabilize (Howard et al. 2010, McKeever et al. 2012). However, the prices of certain home heating fuels, especially heating oil, are unpredictable (Taylor 2006), and it is a proven fact that residential use of wood for home heating is directly influenced by costs of other home heating fuels (Hardie \& Hassan 1986). Green energy in the form of firewood is 
readily available from local forests, and is becoming more popular as either a primary or supplemental energy source for home heating as heating oil prices rise yet again (Nicholls \& Miles 2009, Borchert et al. 2010). In fact, residential consumption of wood energy has increased $34 \%$ since the 2000 census, faster than any other heating fuel, including solar and natural gas (Alliance for Green Heat 2013). This will result in more individuals practicing firewood production either for personal use or income. Unfortunately, firewood regulations are not keeping up with its increased use and the market remains informal (Runberg 2011), and as a result many producers may be unaware of firewood pests, movement restrictions, safety and other business practices.

The first objective of this research study is to identify firewood producers in the state of West Virginia for the purposes of creating a database. The second objective is to elucidate components of the firewood value chain in West Virginia with a focus on firewood producers, their distribution systems and their production, marketing, safety and wood hygiene practices, utilizing a two-part survey. Therefore, the following literature review will first offer a brief history of firewood usage and residential consumption in the United States and then present information from existing studies of firewood producer practices in an effort to identify knowledge gaps in the industry to be addressed in the survey concerning marketing/business practices, chainsaw and general safety practices/personal protective equipment use and wood hygiene practices. The results of this survey will provide state and private organizations with valuable information that might be used to guide outreach initiatives geared toward promoting and supporting an efficient, safe, and conscientious firewood industry in the state of West Virginia. 


\section{CHAPTER II: Review of Literature}

\section{History of fuelwood use in the United States and West Virginia}

Firewood is the oldest source of energy for cooking and home heating and remains a primary heating source for half of the world's population, both in developing and technologically advanced countries (Lindroos 2011, Nord-Larsen et al. 2011). It was estimated in 1998 that some 30 million U.S. households burned wood for primary or secondary home heating (Houck et al. 1998). Today 2.5 million U.S. homes utilize wood or pellets as a primary heating fuel and another $7.7 \%$ of total U.S. households use it for backup heating, making wood the most dominant renewable residential energy source (Alliance for Green Heat 2013) (Table 1). Individual households are responsible for most fuelwood consumption, using it for both heating and aesthetic enjoyment (Alliance for Green Heat 2011, Howard \& McKeever 2012).

As of 1850 , wood supplied $90 \%$ of the United States' energy needs; by the turn of the century, this dropped to $70 \%$ as anthracite coal became available domestically (Cole 1970). A surge in demand for residential fuelwood arose after the Arab oil embargo in 1973 raised domestic heating fuel prices considerably (Giacoletto 1982, Boguszewski 1983, Hardie \& Hassan 1986, McKeever et al. 2012). Fuelwood consumption reached its peak in the mid-1980s, when it was providing 9-11\% of energy for heat in U.S. homes (Lipfert \& Dungan 1983, U.S. Energy Information Administration 2013). Thereafter, it began to decline until 1998, when consumption began to stabilize (Howard et al. 2010, McKeever et al. 2012, U.S. Energy Information Administration 2013) (Figure 1). 
Table 1. Thousands of households that use wood for primary home heating during the past six winters (October 1- March 31) (EIA 2013).

\begin{tabular}{l|ccccccc|cc}
\hline \multirow{2}{*}{ REGION } & \multicolumn{7}{|c|}{ Winter of } & \multicolumn{2}{c}{ Forecast } \\
\cline { 2 - 11 } & $\mathbf{0 6 - 0 7}$ & $\mathbf{0 7 - 0 8}$ & $\mathbf{0 8 - 0 9}$ & $\mathbf{0 9 - 1 0}$ & $\mathbf{1 0 - 1 1}$ & $\begin{array}{c}\text { Average } \\
\mathbf{0 6 - 1 1}\end{array}$ & $\mathbf{1 1 - 1 2}$ & $\mathbf{1 2 - 1 3}$ & $\begin{array}{c}\text { \% } \\
\text { change }\end{array}$ \\
\hline Northeast & 375 & 416 & 477 & 504 & 522 & 459 & 555 & 598 & 7.7 \\
Midwest & 502 & 531 & 587 & 621 & 632 & 575 & 640 & 662 & 3.4 \\
South & 544 & 561 & 597 & 590 & 603 & 579 & 620 & 630 & 1.7 \\
West & 682 & 683 & 707 & 726 & 739 & 708 & 749 & 752 & 0.3 \\
\hline TOTAL & 2104 & 2191 & 2368 & 2441 & 2496 & 2320 & 2564 & 2642 & 3.0 \\
\hline
\end{tabular}

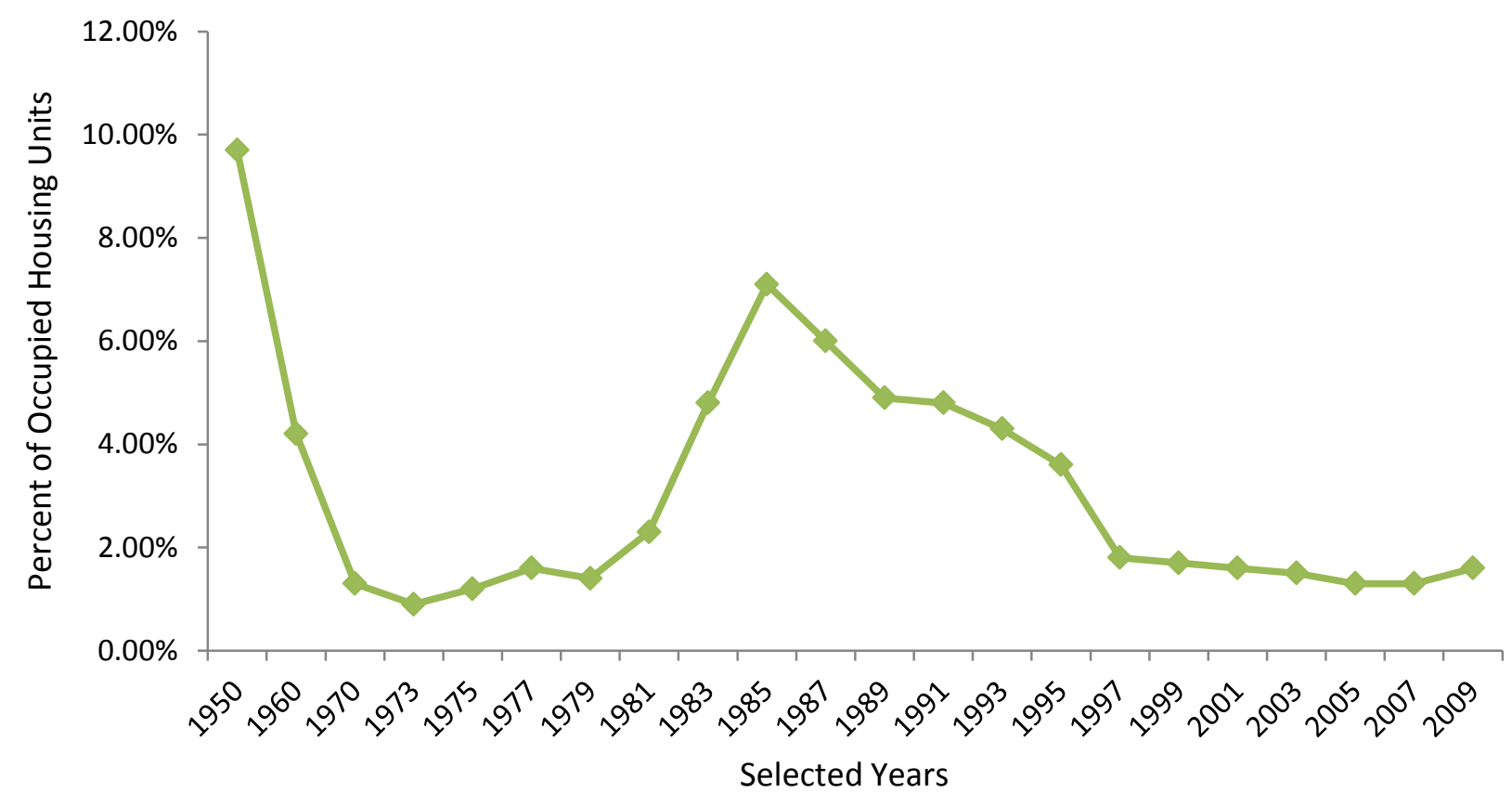

Figure 1. Percent of U.S. households utilizing wood energy for home heating for selected years 1950-2009, (EIA 2013).

However, the biofuel market in the U.S., which includes fuelwood, should be expected to develop considerably in the coming years, due to the volatility of oil and natural gas prices, improved design and efficiency of newer wood-burning stoves and more households using backup wood stoves for primary heating (McKeever et al 2012, Alliance for Green Heat 2013). In fact, residential wood and pellet consumption has risen faster than any other heating fuel34\% between 2000 and 2010, according to U.S. Census data (Alliance for Green Heat 2013). 
Energy independence is a typical target for government policy, so the federal government encourages green energy use by offering tax credits for homes using high-efficiency wood stoves (United Nations Economic Commission for Europe and Food \& Agriculture Organization of the United Nations 2009, Alliance for Green Heat 2011). Residential demand for wood fuel has not decreased even in the midst of economic crisis and in states where relatively cheaper natural gas is available; in fact, it is expected to increase (UNECE \& UNFAO 2009, U.S. Department of Energy 2010, Alliance for Green Heat 2011, Lindroos 2011).

Fuelwood remains a competitive heating fuel when compared to the price of importing fossil fuels to a region (Steklenski et al. 1987, Zerb and Skog 2008) (Table 2). It also stimulates local and rural economies by creating some local employment and keeping energy dollars from bleeding out of a region through the purchase of imported fossil fuels (Bradley 1987, Steklenski et al. 1987, Platt 1987, Skog 1989, Levan 1998, Gorman \& Elder 2009). In fact, according to a technical report generated for the USDA Forest Service by Lichty and others, a local economy can be improved in two ways: by increasing exports or substituting for imports; producing fuelwood accomplishes both objectives (1987). 
Table 2. Comparison of cost per million BTU of various heating fuels (EIA updated 6/5/13).

\begin{tabular}{llrcc}
\hline Fuel Type & Fuel Unit & $\begin{array}{c}\text { Fuel Price } \\
\text { Per Unit } \\
\text { (dollars) }\end{array}$ & $\begin{array}{c}\text { Fuel Heat Content } \\
\text { Per Unit (Btu) }\end{array}$ & $\begin{array}{c}\text { Fuel Price Per } \\
\text { Million Btu } \\
\text { (dollars) }\end{array}$ \\
\hline Fuel Oil (\#2) & Gallon & $\$ 4.02$ & 138,690 & $\$ 28.95$ \\
Electricity & KiloWatt-hour & $\$ 0.12$ & 3,412 & $\$ 34.22$ \\
Natural Gas $^{1}$ & Therm $^{2}$ & $\$ 0.75$ & 100,000 & $\$ 7.54$ \\
Propane $^{3}$ & Gallon & $\$ 2.44$ & 91,333 & $\$ 26.68$ \\
Wood $^{3}$ & Cord & $\$ 150.00$ & $22,000,000$ & $\$ 6.82$ \\
Pellets $_{\text {Corn (kernels) }}{ }^{3}$ & Ton & $\$ 250.00$ & $16,500,000$ & $\$ 15.15$ \\
Kerosene & Ton & $\$ 200.00$ & $14,000,000$ & $\$ 14.29$ \\
Coal (Anthracite) & Ton & $\$ 4.41$ & 135,000 & $\$ 32.65$ \\
\hline
\end{tabular}

${ }^{1}$ Therms or hundreds of cubic feet (ccf)

${ }^{2}$ One therm $=100,000 \mathrm{Btu}$, and is equivalent to about $97.752 \mathrm{cubic}$ feet (or $0.978 \mathrm{ccf}$ ), when there are 1,023 Btu/cf.

${ }^{3}$ The heat content for a cord of wood varies by species and moisture content; 20 million Btu /cord is a rough approximation. Price is average advertised by WV producers on Craigslist between 2012 and 2013 heating seasons.

Fuelwood is especially important in rural areas where fossil fuels are expensive to import and wood is more readily available on nearby forest land: a 1984 national telephone survey found that rural consumers only had to travel an average of 13 miles one way to harvest their wood for fuel, as opposed to the national average of 22 miles (Skog \& Watterson 1984). Residential use of wood for home heating has proven to be directly influenced by the cost of alternative home heating fuels (Hardie \& Hassan 1986, Skog 1989). Rural areas are especially sensitive to fossil fuel price fluctuations - heating fuel prices are especially volatile, since they depend on crude oil prices, and over the last eight winters, heating fuel prices have risen more than gasoline prices (Skog 1989, U.S. Energy Information Administration 2012). In comparison, fuelwood has demonstrated price stability through the years (Kays 2012). Part of this stability is due to the relatively high net energy - the usable energy left after generating (extracting, processing, etc.) a unit of energy in question and transporting it to its end use - of wood fuel in its most unprocessed state: firewood (Hall \& Klitgaard 2011, Gulland 2013).

The same 1984 nationwide telephone survey revealed that rural households consumed more fuelwood: an average of 2.7 cords each, as compared to the national average of 1.8 cords 
per household. West Virginia in particular was among the top ten states in firewood consumption that year (Skog and Watterson 1984). In 1989, Skog conducted a similar study and found that West Virginia accounted for four of the ten counties in the mid-Atlantic region with the highest estimated average fuelwood use over all households (Webster, Pocahontas, Pendleton and Tucker) and three of the ten counties in the region with the highest estimated percentage of wood burners (Webster, Pocahontas and Hampshire) (1989). Today West Virginia remains among the top ten states with the highest per capita primary wood heating $(6 \%)$, behind Vermont (15\%), Maine (12\%), Montana (8\%), New Hampshire (8\%) and Idaho (7\%). In fact, since 2000, wood has outcompeted propane as a primary heating fuel in West Virginia (as well as Maine and Vermont); this is the first time this has happened in an eastern state since 1970 (Alliance for Green Heat 2011).

In addition to being a reliable source of energy for heat, fuelwood is also environmentally friendly in that when it is burned it emits the least amount of carbon dioxide per kilowatt hour of energy emitted, compared with fossil fuels (Steklenski et al. 1987, MacIntyre 2007). In fact, fuelwood emits less than 5\% net carbon dioxide, because it is releasing only the carbon the tree stored over its lifetime and the carbon dioxide produced from the use of mechanical equipment to harvest and transport it (Paul et al. 2003, Zerbe \& Bergman 2004, Bergman \& Zerbe 2008, Nord-Larsen et al. 2011) (Table 3). The removal of dead, dying or undesirable trees for fuel also improves the health of a forest and reduces fuel load for forest fires, if implemented correctly (Skog 1989, Bergman et al. 2008). This concept will be further discussed in the section entitled Wood Hygiene and Forest Health (page 15).

Historically, fuelwood has also been a philanthropic gift to those less fortunate (Cole 1970). All people need warmth, regardless of socioeconomic status, and firewood has been identified as a basic staple of rural poor by Sarkar and Ghosh (2000) and Adams (2008). Firewood is a symbol of self-sufficiency, providing energy independence in the event of a power outage or shortage of other fuels and also giving the producer a sense of accomplishment (Alaska Department of Natural Resources undated, Maine Department of Conservation 2012). The rural poor often process and sell forest products such as firewood when other employment is unavailable, on a part-time basis (Warner 2000). Older family forest owners in Sweden were 
found by Carlsson (2003) to have attached significance to the activity; they enjoy it and find it satisfying recreationally.

Table 3. Net carbon dioxide emitted by various residential heating fuel systems (MacIntyre 2007).

\begin{tabular}{lcc}
\hline & \multicolumn{2}{c}{ Kg carbon / year } \\
\cline { 2 - 3 } Fuel type & From & To \\
\hline Wood pellet boiler system & 125 & 275 \\
Oil central heating: A-rated & 935 & 2005 \\
Gas central heating: typical of stock & 935 & 1940 \\
Bulk LPG central heating & 860 & 1845 \\
Modern electric storage, automatic control & 1425 & 3215 \\
Firewood* & 11 & 24 \\
\hline
\end{tabular}

*Figures were added in by author (MacIntyre 2007), using the midpoint 46g of CO2/available $\mathrm{kWh}$ of delivered heat for pellets, for comparison. Logs used in log boilers and log burning stoves give off $4 \mathrm{~g} \mathrm{CO} /$ available $\mathrm{kWh}$.

Despite its various benefits as a heating fuel, wood has its drawbacks. Due to its recognition by the federal government as a vector for invasive forest insects and disease, the transport and sale of fuelwood, or "firewood," is limited. As mentioned in the Introduction, the USDA Animal and Plant Health Inspection Service's National Firewood Task Force defines firewood as wood less than 4' in length that is intended for use as a heating fuel (Borchert et al. 2010, National Firewood Task Force 2010). Invasive species are defined as any foreign plant, pest, disease or weed that, if allowed to run unchecked, can harm ecosystems, the economy and even humans (USDA APHIS 2010). This is because these alien species are entering areas where natural controls such as predation, climate and other factors are absent, so these invasive species are given free rein to multiply and spread (Campbell \& Schlarbaum 1994). Some of these species are spread by wind, ocean currents and other natural processes, but most are spread anthropogenically, and in today's global market international trade opens up many new borders to these invaders hitching a free ride on imported goods (USDA APHIS 2010, Bigsby et al. 2011). If caught early enough, many species can be held in check and cause minimal damage. However, approximately 360 invasive forest insect species are known to cause losses of over $\$ 7$ billion annually in the U.S. forest products industry; of these alien insect species, $30 \%$ are considered a serious threat, contributing \$2.1 billion in losses (Pimentel et al. 2004). 
By transporting firewood further than 50 miles to go camping, hunting, stay in a second home or deliver to customers, people are allowing these insects to hitch a ride to new areas they might not have otherwise reached by natural flight range or dispersal (Seeland 2007, Jacobi et al. 2011). This allows them to spread much faster and cause more damage (Jacobi 2007, Bigsby 2011). Local, state and federal governments usually respond by imposing regulations and quarantines regarding firewood movement, and utilizing targeted outreach education (National Firewood Task Force 2010, Bigsby 2011). The biology of invasive insects, how they relate to firewood, and their associated regulations will be discussed further in the section on Wood Hygiene and Forest Health (page 15).

Although consumers of firewood such as campers and other recreationists have been the subject of much research and outreach activity, not much has been directed toward producers of firewood (Giacoletto 1982, Jacobi 2007). Cole (1970) stated that despite the historical usage of fuelwood, not much is known about the industry in the United States, and no historical marketing mechanism is evident. Smaller firewood producers do not have any state or nationwide organization (Seeland 2007). It is difficult to estimate fuelwood consumption and production (Jacobi 2007, Seeland 2007) because of the variety of volumes employed throughout the country and the fact that households tend to overestimate consumption (Lindroos 2011). A study of telephone surveys used to determine fuelwood consumption in the U.S. found that the average forestland owner overestimates the volume of a standard cord by $17 \%$; those who loosely stacked their firewood overestimate by $27 \%$ (Wharton 1991).

There are even fewer contemporary studies on firewood production (Giacoletto 1982). The market is extremely informal: most studies were conducted in the 1980s when fuelwood consumption was at its highest, during the first energy crisis, and pertained to projecting future effects of demand for firewood on the health of U.S. forests (Boguszewski 1983, McKeever \& Hatfield 1984, Skog 1989). Over the last ten years, as biofuels such as firewood are gaining popularity once again in the face of rising fossil fuel prices, there has been a resurgence of firewood studies (Lindroos 2007). However, since firewood has been recognized by the federal government as a vector for invasive forest insects and diseases, these contemporary studies have been geared toward consumer movement of firewood and the biology of the insects and diseases that can be transported in it; little research or state reporting efforts have been carried out to 
explore who cuts firewood, where it comes from and how far it is transported before it is burned. Even less research has been performed on business or management practices in the industry (Nybakk et al. 2012).

The increase of non-native invasive species into U.S. ports has resulted in a critical need to define the U.S. fuelwood industry and identify knowledge gaps among the public that could put the health of our forests at risk (APHIS 2010). As firewood producers are usually among the first to lay their hands on the raw wood used to produce firewood, it is crucial that firewood value chains and distribution patterns be studied to facilitate control over potential spread of invasive pests, among other reasons which will be discussed. As of 1984, Marsinko characterized the firewood industry as still being disorganized and underdeveloped. Firewood is a non-uniform product that is available in a variety of sizes, lengths and moisture contents, can be sold split or whole, and can be delivered to or picked up by the consumer in many different quantities or volumes (Skog \& Watterson 1984). Anyone can produce firewood, and there is no specific licensing or training required to do so (Reineke 1965). Firewood remains to this day a relatively unmonitored and unstandardized "raw wood" product that the public moves informally (Borchert et al. 2010).

In order for West Virginia (and nationwide) forests to remain healthy, fuelwood production will need to be researched and more closely monitored as an industry. Outreach education will hone producer skills, standardization will protect the consumer and firewood Best Management Practices will protect the well-being of forests, producers and consumers alike; ultimately the West Virginia fuelwood industry will be strengthened through a collaborative network of dedicated firewood producers. Existing literature pertaining to the three main focuses of this Best Management Practices approach will now be reviewed in the next three sections on Marketing and Business Practices; Wood Hygiene and Forest Health; and Safety and Personal Protective Equipment Use. 


\section{Marketing \& Business Practices}

Economically, firewood is an emerging industry, despite its historical usage. It was the most dependable cash crop for farmers at the turn of the century as more and more households began purchasing their fuelwood instead of producing their own (Cole 1970). Using their 1984 national telephone survey results, Skog and Watterson (1984) estimated fuelwood sales for the 1980-1981 heating season at \$622 million — this level of revenue, they claimed, would place a single fuelwood operation among the top 500 companies in the United States at the time; and these sales only represented one quarter of consumed firewood. Indeed, fuelwood was the main product of U.S. timberlands in the mid- to late-1980s, surpassing the output of all other products combined, including timber, pulp and paper (Koning, Jr. \& Skog 1987).

Yet today there are still many individuals engaging in the traditional method of firewood production — a man, a chainsaw and a pickup — from felling to processing, which is a very inefficient system that does not lend itself to expansion. Andrews and Dammann (1978) characterized these producers in New Hampshire selling less than 50 cords per year as "small volume operators." Many traditional producers in Finland began selling because they already cut personal use firewood from their own woodlot for free, and identified an additional tax-free income source (Raitila 2008). These smaller firewood producers have no business model, work for themselves on their own time, have a varying number of suppliers; generally do not have business premises or advertise beyond word of mouth or in local papers; have no delivery schedule and are generally unable to keep up with demand (Andrews \& Dammann 1978, Driscoll et al. 2000, MacIntyre 2007, Raitila 2008, Gorman \& Elder 2009).

The firewood industry in the United States and abroad remains unorganized: a "grey" market where standard volumes, records and receipts are rare and it is easy for anyone to sell firewood once or regularly (Andrews \& Dammann 1978, MacIntyre 2007). Many smaller Finnish producers utilize wood from their own private woodlots, or those of friends or family (Raitila 2008). Many producers in Australia are also smaller operations without business premises, selling less than 500 metric tons per year and operating outside of any regulated system (Driscoll et al. 2000). The majority (75\%) of Illinois producers surveyed in 1980-81 also had smaller operations, selling less than 25 cords per year and obtaining $96 \%$ of their raw wood 
from private lands (Giacoletto 1982). The pickup truck remains the typical measure and means of transport for smaller producers, and most do not bother to market their product beyond local papers and word of mouth, hesitant to generate too much demand (Marsinko 1984). A survey of producers in Pennsylvania in 2008 found that the primary customer base of most was private buyers for personal use (Ellis et al. 2008); domestic users were also the main customer base for Scottish producers surveyed in 2006 (MacIntyre 2007).

Producing firewood is not the most lucrative or efficient means of procuring a livable income for smaller operations. Andrews and Dammann predicted that firewood vendors in New Hampshire in 1978 would not be able to make a living selling less than 250 cords per year (Andrews \& Dammann 1978). As of 2010, there were only 1,093 reported firewood businesses operating in the United States, $82 \%$ earning less than $\$ 500,000$ annually (Borchert et al. 2010). According to a 1983 academic thesis study of domestic fuelwood consumption in West Virginia conducted by West Virginia University graduate student Joy Boguszewski, it takes 15.7 hours to produce a standard cord of firewood, from felling to stacking, excluding delivery. Producers will rarely break minimum wage if they want their prices to be competitive with other fuels (Hahn 1982, Boguszewski 1983). In addition, smaller operations typically do not employ more than one or two individuals (Marsinko 1984, Raitila 2008). In many cases, helpers are typically family members: Norwegian producers surveyed in 2010 reported family members as the predominant social group with whom they cooperated. This same study also found that producers that have this closed network of family members may stick to the same business model and not reach their full business potential because they are missing out on new ideas (Nybakk et al. 2012).

Firewood is a bulky fuel and its weight can vary depending on moisture content, so its transport can be costly (Steklenski et al. 1987). Gasoline prices are a big expense for producers having to travel to harvest or deliver (UNECE \& UNFAO 2009). According to a 1984 survey of producers in Greenville, North Carolina, owners of pickup-based operations "either lost money or barely broke even at a $\$ 5.00$ per hour wage rate" (Marsinko 1984 p. 179). Another issue contributing to this small profit margin is the fact that firewood as a product is not standardized or regulated, so it is generally not priced properly; producers may lose money on delivery, since some may not consider it part of the firewood production process itself (Raitila 2008). Pricing 
can also vary by region and according to the volume of firewood sold, whether it is split or round, whether it is green or seasoned and whether the load is a particular species or a mix (MacIntyre 2007, Nicholls \& Miles 2009). Since firewood production is so labor-intensive, the more a smaller producer processes and handles a load of firewood, the more time he invests in it and thus the more expensive the load will be (Reineke 1965, Smith 1981). Also the denser hardwoods with more BTUs per cord such as oak, hickory, hard maple and locust may fetch a premium in pure loads (Table 4). Some producers may save money by allowing customers to come pick up their own firewood (Marsinko 1984). Firewood may also fetch higher prices in areas with more of an urban population, according to a study of Illinois producers (Giacoletto 1982).

Table 4. Comparison of BTU content of various species of trees used for firewood and various non-wood heating fuels (NJ DEP undated).

\begin{tabular}{lccc}
\hline & \multicolumn{3}{c}{ Species } \\
\cline { 2 - 4 } & Black Locust & Red Oak & Hard Maple \\
\hline $\begin{array}{l}\text { Available Heat/cord } \\
\text { (Million BTUs) }\end{array}$ & 14.6 & 12.3 & 11.9 \\
\hline To get the equivalent BTUs of one cord of wood you would need: \\
\hline Coal (tons) & 1.46 & 1.23 & 1.19 \\
Fuel Oil (gallons) & 160 & 135 & 130 \\
Natural Gas (100 cuft) & 195 & 164 & 158 \\
Propane (gallons) & 216 & 182 & 176 \\
Electricity (kwt hours) & 4275 & 3606 & 3476 \\
\hline
\end{tabular}

Firewood quality in itself is also extremely variable: it can be produced in a variety of lengths and widths, split or un-split, clean, riddled with mold or mud, and of any moisture content depending on whether and how long it was seasoned (Skog \& Watterson 1984, MacIntyre 2007). A survey of producers in Scotland found that most producers do not know the moisture content of their firewood but do season it (MacIntyre 2007). Dry wood starts easier, burns cleaner and hotter than green wood, combusting more completely and creating significantly less ash and creosote in chimneys, and less pollution overall (Baker 1982, Ochterski 2006). Freshly-cut firewood may have a moisture content of $50 \%$ or more; this extra moisture depletes energy to burn off as water vapor, cooling the fire and literally reducing the heating 
value of a cord of firewood by more than 1,000 BTUs (British Thermal Units: the amount of energy it takes to raise the temperature of 1 pound of liquid water by $1^{\circ} \mathrm{F}$ at a constant pressure of one atmosphere) per pound of water at higher moisture contents (Zerbe \& Bergman 2004, Nord-Larsen et al. 2011, Curkeet 2011).

Volumes of firewood used in the industry are also notoriously ambiguous. Although the department of Weights and Measures in most states only allows firewood to be sold in cords (128 cubic feet of stacked solid wood, bark and air that typically measures $4 \times 4 \times 8$ ') or fractions of cords, outlawing the use of "rack," "pile," "truckload," or similar ambiguous terms when advertising or selling firewood, this is not enforced unless a consumer files a complaint (Jacobi 2007, Seeland 2007). A study conducted by Marsinko and Wooten (1983) found that the common conversion factors utilized by producers who deliver with pickups (bed length times width times height) tends to greatly overestimate the volume of firewood delivered, since most pickup trucks can hold anywhere from less than $1 / 2$ cord to over $1 / 2$ cord, depending on the size of the bed and how the wood is loaded. The cord itself can vary 60-110 cubic feet of solid wood depending on the length and diameter of the pieces, whether they are split or un-split, whether they have deformities and how they are stacked (Smith 1981, Marsinko et al. 1984, Zerb \& Bergman 2004, Nicholls \& Miles 2009). Confusion of the term "cord" with "pile" or "truckload" in many regions of the country tends to be age-related, as the term was in more frequent use by older generations (Marsinko et al. 1984). Many firewood producers surveyed in Australia in 2000 could not give accurate estimates of the amount of firewood they sold, and also typically characterized it in truck loads (Driscoll et al. 2000).

Larger operations have more of a chance of keeping up with demand and earning reportable income, but are more costly due to the need for space for storage and seasoning, employees and the expenses of delivering. Currently there is limited information on the amount or source of commercial firewood in the U.S. (Jacobi 2007). A study of producers in Finland found that these larger producers are more able to invest in their business to make production easier, such as purchasing newer technology (processors, hydraulic splitters, etc.) and/or hiring help. These larger Finnish producers tend to purchase a lot of their raw wood and focus mainly on processing; some may even hire sub-contractors (Raitila 2008). 
The fuelwood industry can reasonably be expected to "evolve" in the face of increasing demand due to rising non-wood fuel prices, as evidenced by several firewood producer studies conducted in New Hampshire (Andrews \& Dammann 1978, Evans \& Parker 1987). In the late 1970s, the typical firewood producer had a very small operation, selling less than 50 cords per year (Andrews \& Dammann 1978). By 1985, 859 fuelwood producers were known to be in operation in the state, with $65 \%$ of the 200 survey respondents reporting annual production exceeding 100 cords; these producers were supplying 94\% of total annual output. One-third of these respondents reported having enlarged their operations within the previous five years; while others expressed interest in expanding, should the market allow it. Many of these producers were loggers and sawmill owners who realized that they could diversify their business models by selling unmarketable timber as firewood, since they already had the equipment for the production and delivery of large volumes (Evans 1985).

\section{Wood Hygiene \& Forest Health}

\section{Invasive Species of Concern}

It is estimated that in 2000, the United States experienced nearly $\$ 137$ billion in damages from invasive species (Perrings et al. 2002). Much of this expense can be attributed to the Emerald Ash Borer (EAB) (Agrilus planipennis), the Asian Long-horned Beetle (ALB) (Anoplophora glabripennis) and the European Gypsy Moth (EGM) (Lymantria dispar), three of the most likely invasive pests to be found in hardwood firewood coming from within and around the state of West Virginia. Not only do these invasive insects cause losses in the forest industry and disrupt ecosystems, they also cost the United States millions in eradication and other control tactics (Mooney \& Cleland 2001, Kovacs et al. 2010).

It is very difficult to ascertain the economic costs incurred by the United States for controlling these invasive insects, but the U.S. Forest Service as of 2004 was spending close to \$11 million annually on the management of EGM alone (Campbell \& Schlarbaum 1994, Pimentel et al. 2004). According to a study conducted by Kovacs et al. (2010), 25 states in the U.S. can expect to incur a mean discounted cost of $\$ 10.7$ billion in costs for treatment and/or removal and replacement of ash trees by the year 2019; if all 37.9 million ash trees in this area are treated and/or removed and replaced on developed lands in residential areas, this figure is 
more like $\$ 25$ billion. Another estimate from the USDA to remove and replace dead and dying ash trees over the next 25 years was $\$ 7$ billion (Wang et al. 2011). As for Asian long-horned beetle, the U.S. spent \$225 million between 1997 and 2006 on eradication programs (Hajek \& Bauer 2009). The main issue is that those who are responsible for the spread of invasive species typically are not responsible for the costs; these costs are usually externalized, burdening the general public and future generations (McNeely 2000). A summary of the discovery year and country/region of origin; mode of introduction; host trees and how each insect inflicts damage on them; how the biology of each insect lends to its transportation in firewood; and an idea of associated economic costs from control or eradication tactics employed in the U.S. can be found in Table 5. 
Table 5. Relevant facts on the invasive insects that could be transported in firewood from within and around the state of West Virginia.

\begin{tabular}{|c|c|c|c|c|c|c|}
\hline $\begin{array}{c}\text { Pest } \\
\text { Name/Latin } \\
\text { Name, Year } \\
\text { of Discovery }\end{array}$ & $\begin{array}{l}\text { Country/ } \\
\text { Region of } \\
\text { Origin }\end{array}$ & $\begin{array}{c}\text { Mode of } \\
\text { Introduction }\end{array}$ & Hosts & $\begin{array}{c}\text { Nature of the Threat } \\
\text { to Host Trees }\end{array}$ & $\begin{array}{l}\text { Biology } \\
\text { Lending to } \\
\text { Transport in } \\
\text { Firewood }\end{array}$ & $\begin{array}{l}\text { Associated Losses, Control } \\
\text { and/or Eradication Costs }\end{array}$ \\
\hline $\begin{array}{l}\text { Emerald Ash } \\
\text { Borer/ } \\
\text { Agrilus } \\
\text { planipennis, } \\
2002\end{array}$ & Asia & $\begin{array}{l}\text { Imported in } \\
\text { untreated } \\
\text { wooden } \\
\text { packing } \\
\text { material }\end{array}$ & $\begin{array}{l}\text { All } 16 \text { species } \\
\text { of ash in North } \\
\text { America }\end{array}$ & $\begin{array}{l}\text { Larvae develop under } \\
\text { bark, creating galleries } \\
\text { that girdle the trunk } \\
\text { and branches, cutting } \\
\text { off nutrients, causing } \\
\text { crown dieback and } \\
\text { inevitable death }\end{array}$ & $\begin{array}{l}\text { Larvae can } \\
\text { overwinter up } \\
\text { to two years } \\
\text { developing } \\
\text { within host } \\
\text { wood, evading } \\
\text { detection }^{1}\end{array}$ & $\begin{array}{l}\text { America's ash resources } \\
\text { valued at } \$ 282 \text { billion }^{2}\end{array}$ \\
\hline $\begin{array}{l}\text { European } \\
\text { Gypsy Moth/ } \\
\text { Lymantria } \\
\text { dispar, } 1889\end{array}$ & $\begin{array}{l}\text { Western } \\
\text { Europe and } \\
\text { Asia }\end{array}$ & $\begin{array}{l}\text { Brought to the } \\
\text { U.S. in } 1869 \text { by } \\
\text { Leopold } \\
\text { Trouvelot, who } \\
\text { wanted to break } \\
\text { into the silk } \\
\text { industry }\end{array}$ & $\begin{array}{l}\text { Prefers oaks } \\
\text { and aspen, but } \\
\text { feeds on the } \\
\text { foliage of } \\
\text { hundreds } \\
\text { species of trees } \\
\text { and shrubs }\end{array}$ & $\begin{array}{l}\text { Larvae may repeatedly } \\
\text { defoliate host trees, } \\
\text { weakening them over } \\
\text { time by forcing them } \\
\text { to deplete their energy } \\
\text { reserves in order to } \\
\text { grow new leaves }\end{array}$ & $\begin{array}{l}\text { Flightless } \\
\text { female lays } \\
\text { durable egg } \\
\text { sacs on any } \\
\text { stationary } \\
\text { outdoor object }\end{array}$ & $\begin{array}{l}\text { Economic cost of gypsy } \\
\text { moths has averaged } \$ 30 \\
\text { million a year for the past } 20 \\
\text { years, mostly due to } \\
\text { quarantines imposed on } \\
\text { timber and agricultural } \\
\text { products }^{5}\end{array}$ \\
\hline $\begin{array}{l}\text { Asian } \\
\text { Longhorned } \\
\text { Beetle/ } \\
\text { Anoplophora } \\
\text { glabripennis, } \\
1996\end{array}$ & Asia & $\begin{array}{l}\text { Imported in } \\
\text { untreated } \\
\text { wooden } \\
\text { packing } \\
\text { material }\end{array}$ & $\begin{array}{l}\text { Prefers maples, } \\
\text { but feeds on } \\
\text { species from } 13 \\
\text { genera of } \\
\text { hardwoods }\end{array}$ & $\begin{array}{l}\text { Larvae bore deep into } \\
\text { the living tissue of the } \\
\text { tree, damaging it and } \\
\text { cutting off the flow of } \\
\text { nutrients }\end{array}$ & $\begin{array}{l}\text { Larvae bore } \\
\text { deep into host } \\
\text { wood, evading } \\
\text { detection }\end{array}$ & $\begin{array}{l}\text { Not currently in WV, but the } \\
\text { state is at-risk since ALB is in } \\
\text { OH. ALB has the potential to } \\
\text { cause more damage than } \\
\text { Dutch elm disease, chestnut } \\
\text { blight and EGM combined }^{6}\end{array}$ \\
\hline
\end{tabular}

1 Petrice \& Haack 2007, Haack 2008, Borchert et al. 2010
2 Duerr \& Mistretta 2013

3 Duerr \& Mistretta 2013
4 USDA Forest Service 2003

5 WA Invasive Species Council 2012

6 USDA APHIS 2011 


\section{The Role of Firewood in Invasive Species Transport}

Although the transport of forest insects and disease in firewood is not a new phenomenon, there has been an unprecedented increase over the past twenty years of exotic bark and wood-boring insects such as EAB and ALB being transported; in fact, between 1985 and 2005, there were 25 newly discovered invasive wood-boring insects being transported in firewood (Haack 2006). In another firewood survey conducted in Michigan by intercepting vehicles on the Mackinac Bridge in 2010, Haack and others (2010) found that out of 1,045 pieces examined, $23 \%$ had live borers and $41 \%$ had evidence of previous infestation.

The biology of borers such as EAB and ALB includes a period of larval gestation under the bark or deep in the heartwood of host trees, while EGM lays its indestructible egg sacs on any stationary object. Borers in particular tend to target stressed or dying trees, which are also trees that are typically selected for firewood, so it is not difficult to see how these insects can be transported in firewood (Haack et al. 2010). Because firewood is minimally processed and transported in a relatively short amount of time, these invasive insects and diseases can survive into new areas (Jacobi 2007, Haack 2008, Borchert et al. 2010). For these very reasons, the USDA has identified firewood as a prime vector for transporting these invasive forest insects outside of their respective natural dispersal ranges (Borchert et al. 2010, National Firewood Task Force 2010). Infestations are more common in highly-populated areas where trade and human movement occur more frequently (Borchert et al. 2010, Haack et al. 2010). Eastern forests are more susceptible to invasion by these alien species because intercontinental trade routes were first established on the east coast (Campbell et al. 2002).

Firewood can harbor wood borers for three years or more and decay, canker or vascular stain/wilt fungi with the bark on or off (Jacobi 2012). Therefore, ideally, firewood should be debarked and then air dried for up to three years under cover, or dried in a kiln. Most small producers only minimally season their firewood: in Scotland, 26\% of producers surveyed in 2007 reported seasoning their firewood for 6-12 months (MacIntyre 2007). There are many informational resources available suggesting myriad drying times for firewood, but ultimately it depends on the species (since they can vary in density), size of the individual pieces, location of storage and local climate (Baker 1983). According to Robert Haack (2008) of the Northeast 
Research Station, firewood should be seasoned for two years or more, because emerald ash borer adults have been known to emerge from even summer-cut wood for up to two years.

\section{Using Firewood to Manage Forest Health}

Not only is firewood a good supplemental source of income for forest land owners, but it also gives them incentive to clean up their woodlots (Levan 1998, Finley 2009). Performing small-scale harvesting for firewood not only enhances habitat for different animal and plant species, it also frees up nutrients and light for crop trees because trees typically removed for

firewood are dead, diseased, weak or otherwise undesirable (Kliene 1986, Koning, Jr. \& Skog 1986, Skog 1989, Gardner 1995, New Jersey Department of Environmental Protection 2007, Finley 2009). This improves the growth rate and overall health of the remaining trees in the stand (Koning, Jr. 1984, Gardner 1995). Producers should have a plan with management objectives before simply marching into the woods and cutting down any tree, and exercise the firewood Best Management Practices that will be discussed on page 24 when harvesting.

\section{Firewood Quarantines and Regulations}

Many alternative home heating fuels like firewood have historically been lightly regulated because of their social benefit (Seeland 2007). However, state and federal governments have been attempting to minimize the movement of invasive forest insects for many years; the former enacts intrastate or county quarantines and the latter interstate quarantines (Seeland 2007, Kovacs et al. 2010). New York was the first state with firewood regulations prohibiting the movement of untreated firewood into the state and within the state over distances of greater than 50 miles. Currently 28 states have regulations restricting the movement of raw logs, for internal or external quarantines. Sixteen of these states have regulations restricting the movement of all hardwood firewood explicitly, since individual species are generally unidentifiable by inspectors, but it has proven difficult for regulatory agencies to enforce these regulations (Poland et al. 2008, Tobin et al. 2010, Runberg 2011).

Many state and federal regulations include restrictions on movement of firewood and also require sanitization of firewood from infested areas. Distance restrictions may limit the market available to smaller producers, since they generally lack the knowledge and financial means to comply with firewood sanitization requirements, such as heat treatment in a kiln. Firewood 
producers in Pennsylvania surveyed in 2007 did not think it feasible to heat-treat (76\%), remove bark (64\%), fumigate (68\%), or season their firewood for at least two years (44\%) (Ellis et al. 2008). The USDA currently requires a heat sterilization treatment involving firewood reaching a core temperature of $160^{\circ} \mathrm{F}$ for a minimum of 75 minutes in order to properly kill $\mathrm{EAB}$ larvae, but the technology needed to conduct this sanitization is generally unavailable to individual firewood producers. Evaluations of lower temperatures and longer periods in smaller dry kilns that might be more economical have proved to be less effective at eradicating EAB larvae (Goebel et al. 2010). Other studies related to minimizing the risk of transporting emerald ash borer in particular have investigated less costly techniques such as cutting dates and length of seasoning, but are typically not $100 \%$ effective at preventing emerging adults (Petrice \& Haack 2006, Haack 2008, Nord-Larsen et al. 2011).

Not only might these regulations restrict the market, they may also have language that is confusing to the public, which includes firewood producers. In addition, regulations may differ from state to state and depending on the invasive insect or disease of concern (Borchert et al. 2010, Bigsby et al. 2011). Even campgrounds and townships may enact their own regulations, prohibiting outside firewood to be brought in by campers or tourists (Borchert et al. 2010). Another issue is that the firewood industry has both a formal economy in which registered businesses produce and transport firewood between many states, and an informal economy of private individuals producing and selling firewood locally, a dynamic and sometimes inaccessible population with no industry organization (Runberg 2011). Industrial shipping of products may be highly controlled in the U.S., but firewood is still moved within this informal economy by the public (Bigsby et al. 2011). Even commercial firewood is of questionable quality and little is known about its source (Jacobi 2007). Several surveys of retail firewood conducted in Western states have proven that this sector does not have strict standards for firewood hygiene, as much retail firewood may contain insects and be transported hundreds of miles from its origin (Kansas Department of Agriculture 2007, Jacobi et al. 2011, Jacobi et al. 2012).

State and federal governments have invested more time in public outreach over the past ten years, since it has been proven that both outreach education programs developed alongside customary quarantine measures are more successful at involving the public in controlling the 
spread of invasive species in firewood (Runberg 2011). Websites such as emeraldashborer.info (USDA Forest Service, Michigan State University, Purdue University and Ohio State University), hungrypests.com (U.S. Department of Agriculture) and dontmovefirewood.org, which was started by the Continental Dialogue, a collaborative group of organizations and individuals with diverse interests in protecting North American forests from non-native insects and diseases (the website is owned by The Nature Conservancy) provide information and outreach materials for the general public. Signs and information sheets admonishing the transport of firewood have also been posted at most state and national parks and forests and various public and private campgrounds.

These outreach techniques have indeed proven successful: in a 2005 national survey of 817 voters conducted by Fairbank, Maslin, Maullin \& Associates for the Nature Conservancy found that $41 \%$ were at least "very concerned" about insects and disease that kill trees, after learning more from the survey literature, this number rose to $64 \%$. Regional awareness, especially in states affected by specific invasive species, was significantly larger than national awareness of forest pests and pathogens, but at least $53 \%$ of respondents had heard "a little" about these issues (Fairbank, Maslin, Maullin \& Associates 2006). Another two-part survey of Pacific Northwest campers was conducted in 2010 by invasive species councils of Oregon, Washington, and Idaho that involved a pre-survey which highlighted public knowledge gaps that were used to develop a joint Tri-State firewood education campaign. A post-survey revealed that camper knowledge of invasive species in firewood had increased 23\% (Runberg 2011).

\section{Safety and Personal Protective Equipment Usage}

In 2012 there were an estimated 30,509 chainsaw injuries treated in U.S. emergency rooms, according to the Consumer Products Safety Commission's National Electronic Injury Surveillance System; most injuries were incurred by individuals between the ages of 25 and 64 $(\mathrm{n}=21,579)$. Another estimated 11,125 treated injuries were caused by hatchets or axes (2012). Twenty-three reported deaths in 2000 and 66,970 medically treated injuries related to yard and garden equipment in 2001 were associated with consumer chainsaw use and cost these individuals over \$1 million; between 1997 and 2002, injuries resulting from the use of mechanical yard equipment such as chainsaws were most treated in U.S. emergency rooms 
(Rutherford et al. 2003). Basic personal protective equipment (chainsaw chaps, boots, gloves, ear and eye protection and hard hat, or hard hat that includes ear and eye protection) costs less than $\$ 250.00$ (comparing prices from Stihldealer.net, Husqvarna.com and Lowes.com) (Table 6).

Table 6. Cost ranges for personal protective equipment apparel available at various retailers.

\begin{tabular}{lc}
\hline PPE & Unit Cost Range* \\
\hline Apron chaps & $\$ 80-100$ \\
Boots & $\$ 90-300$ \\
Gloves & $\$ 15-50$ \\
Eye protection & $\$ 15-50$ \\
Ear protection & $\$ 15-50$ \\
Hard hat & $\$ 15-20$ \\
Hard hat with ear protection and face shield & $\$ 45-70$ \\
Protective shirt & $\$ 80-100$ \\
\hline
\end{tabular}

* Rough costs were estimated by comparing prices from a Morgantown Stihl dealer on Stihldealer.net, Husqvarna.com and Lowes.com).

Firewood production involves repetitive activity with dangerous mechanical equipment including chainsaws and splitters, so there is great opportunity for severe injury (Lindroos 2007). A telephone survey of individuals who received treatment for woodcutting injuries in Wisconsin emergency rooms in 2005 revealed an alarming rate of injuries related to occasional chainsaw use, tree felling and yard work. Over a third of the reported injuries occurred while an individual was working alone; another third were not wearing any personal protective equipment (PPE) such as a helmet, boots, and ear and eye protection. Most injuries were related to mechanical equipment or being struck by an object (branch) and occurred in the afternoon (between 12 p.m. and 6 p.m.), perhaps reflective of fatigue or the fact that these individuals are working part-time on these activities. The study concluded that self-employed or non-professional individuals who engage in occasional woodcutting are three times more likely to become injured than professional loggers who are required to wear PPE (Fischer et al. 2005).

Another study of Midwestern farmers in 1995 found that these individuals, 92\% of who use a chainsaw once a month or less, did not feel the need to wear PPE since they were exercising "common sense" and being careful. Reasons for not wearing PPE included comfort, time and cost; personal grooming and health conditions were also directly related to PPE use 
(Carpenter et al. 2002). In addition to the lack of PPE usage, studies of families involved in selfemployed forestry operations and small-scale firewood processing in Sweden have proven that these individuals do not engage in these activities often and so thus may lack the experience and knowledge necessary to make proper assessments about the risks involved (Doyle \& Conroy 1989, Fischer et al. 2005, Wilhelmson et al. 2005, Lindroos 2007).

Fifty-four percent of the non-fatal accidents experienced by 385 Swedish non-industrial private forest owners (NIPFs) between 1996 and 2001 were caused by firewood production: thirty-seven percent from various woodcutting machines, $33 \%$ from chainsaws and $11 \%$ from axes. Eighty-one percent of respondents in this particular study reported spending less than 31 days per year engaging in forestry-related activities. Twenty-nine percent of the 225 respondents who reported an injury missed some work due to their injuries; fifty percent of cases had persistent symptoms. Sixty-eight percent of the respondents who reported injuries claimed personal responsibility, blaming stress, fatigue, carelessness, conscious risk-tasking and lack of knowledge (Willhelmson et al. 2005). In a similar survey of self-employed Swedish NIPFs in 2008 , half (51.5\%) reported spending less than five days a year producing firewood; half of the accidents reported by family forest owners were therefore firewood-related (Lindroos et al. 2008).

A lack of standardized injury reporting protocol and data on injuries where the individual did not seek medical attention has prompted intense safety research on NIPFs in Sweden, as an issue of public health (Wilhelmson et al. 2005). Occupational safety is studied extensively, but home and leisure accidents such as those related to firewood production are not, even though they account for $75 \%$ of injuries and a significant amount of missed work. Temporary workers such as occasional woodcutters are more likely to incur injury than professional forestry workers. However, because these injuries are not considered "occupational," they may not be included in national safety reports, since these self-employed individuals do not have to comply with safety standards that would otherwise be enforced by an employer (Fischer et al. 2005, Lindroos et al. 2008, Lindroos \& Burström 2010). This lack of data makes it difficult to analyze the safety habits of firewood producers; many may not even recall details of past accidents due to the fact that they do not engage in production often, do not keep track of hours worked, and do not work for an employer that would keep such records (Fischer et al. 2005, Lindroos et al. 2008). 
The use of personal protective equipment greatly reduces the chances of a severe injury, but will not entirely prevent an accident or affect the reasoning of an individual leading up to an accident (Klen \& Vayrynen 1984, Taber 1987, Carpenter et al. 2002). A study of "nearaccidents" (those accidents that would have occurred if PPE had not been in use) by Haar in 1974 found that loggers in Norway had fewer accidents when wearing PPE; many claimed that they believed themselves to be more cautious when not using PPE, to make up for a lack of bodily protection, a phenomenon called "risk compensation" (Drasdo 1969, Klen \& Vayrynen 1984). However, as mentioned before, $68 \%$ of Swedish NIPFs reported that they were personally at fault for the accidents they experienced between 1996 and 2001 (Wilhelmson et al. 2005).

In Wisconsin, surveyed woodcutters gave the top five contributing risk factors that led to their accidents: it could not be avoided, carelessness or inattention, lack of safety equipment or practices, do not know, and haste. When they were given a list of choices, the order of these risk factors changed: could not be avoided, carelessness, haste, fatigue and faulty, improper or inadequate safety equipment. Younger respondents (below the age of 50) admitted personal fault as a factor, while respondents between the ages of 50 and 85 were more likely to report that their injuries were unavoidable; younger respondents also reported more chainsaw injuries, while older respondents were more often hit by an object. This could allude to the fact that these occasional woodcutters are learning to operate mechanical equipment more safely with experience, and their reaction times are slowing with age. Although many respondents thought their injuries could not have been avoided, they also indicated that they were open to developing better safety habits (Fischer et al. 2005). There remains much research to be conducted on the risk-taking decisions of firewood producers (Lindroos et al. 2008).

\section{Best Management Practices}

Best management practices have a long history of being employed in the West Virginia logging industry, and are designed to control soil erosion, sedimentation of waterways and reclaim logging landings (WV Division of Forestry 2005). These practices are also common in other tree care industries such as arboriculture and urban forest planning, so it makes sense to develop a set of similar guidelines for the firewood industry in order to protect forest and 
producer health and safety and also protect the consumer by making firewood dealers and producers more accountable and reliable.

As mentioned in the Introduction to this paper, this project focuses on three aspects of firewood best management practices: business/marketing, safety/PPE use and wood hygiene/forest health. The National Firewood Task Force identifies three components of its own concerning these BMPs: record-keeping, labeling and treatments. Under its recommendation, certified commercial dealers could establish an industry-run national certification program which would require members to keep 2-year records of locations and dates of harvests, tree species harvested, contact information of any sellers and records of sales (quantity, date, contact information of buyer); they would also have to label their firewood units with similar information, including amount sold, treatments used and instructions on how to report any issues of quality including found insects. Small-scale producers would be expected to adopt their own BMPs, such as selling local firewood and making sure that it is pest-free, de-barked and seasoned, especially before transporting it, and to be aware of state and federal regulations regarding invasive species.

Unlike other industries, firewood BMPs would be voluntary guidelines. Many countries, states and provinces have devised their own firewood guidelines. In her study of Scottish firewood merchants, MacIntyre concluded that producers would stand to gain customer loyalty by understanding and responding promptly to customer needs, being prompt and flexible with delivery and providing a consistent, quality product: firewood should be cut to appropriate sizes and lengths, be pest-free and seasoned at least two years or kiln-dried to at most $25 \%$ moisture content. Customers should also be informed of the source and species content of their firewood, which should be priced accordingly (MacIntyre 2007). The USDA Forest Service suggests in a 1965 research note that the best way for firewood producers to appeal to a local market is to study it over time and provide exactly what customers need (Reineke 1965). The Firewood Association of Australia, Inc., has similar voluntary codes of practice for certified dealers concerning legal, sustainable harvesting, moisture content ( $25 \%$ at most), volume measurements, contaminants, accurate product descriptions including species and source, and customer advice on how to season any green wood sold, as well as how to properly burn firewood. This 
certification is backed by the Australian government itself, which regularly collects data on firewood supply and harvest operations (FAA 2008).

Various state extension websites, peer-reviewed journal articles and federal recommendations were explored during the course of this literature review in order to compile a list of possible best management practices for West Virginia firewood producers, which is available in Table 41 of Appendix H. Some of the suggested BMPs may not be appropriate for smaller enterprises that sell within county and/or state lines, but the list is meant to cover basic practices of an honest, reliable and environmentally aware firewood producer. These best management practices will be the guiding force of the outreach objective of this project.

\section{Objective of Study}

This project seeks to answer the following: What does the West Virginia firewood industry look like, and who are the key players? What kinds of individuals are producing firewood in the state of West Virginia, and how receptive are they to outreach, collaboration and increased monitoring of firewood; how do they keep track of and promote their businesses; what kinds of safety practices do they employ in the process of producing firewood, and what kinds of injuries do they incur; how do they provide a clean, quality product to their customers, if any attempt is made at all, and what do they know about invasive forest threats and associated regulations?

The first objective of this research study is to identify firewood producers in the state of West Virginia for the purposes of creating a database. The second objective is to elucidate components of the firewood value chain in West Virginia with a focus on firewood producers, their distribution systems and their production, marketing, safety and wood hygiene practices, utilizing a statewide two-part survey. The results of this survey will provide state and private organizations with valuable information that might be used to guide outreach initiatives geared toward promoting and supporting an efficient, safe, and conscientious firewood industry in the state of West Virginia. 


\section{CHAPTER III: Methodology}

As mentioned in the literature review, many firewood producers operate in an informal or "grey" market, selling a tax-free product. Therefore, in order to protect the confidentiality of firewood producers' business practices and minimize concerns that their privacy was being compromised, the West Virginia Friends of Firewood Network adopted a three-phase approach with a two-part survey. Producers were encouraged to participate for the good of their own business and the industry as a whole. The objective of the study was explained to producers as an exploratory research study being used to identify which educational programs would most benefit their businesses.

The first phase of the project involved compiling a database of producers. This was accomplished by scouring various advertisements and collecting telephone numbers. Telephone numbers advertising firewood for sale are often the only identifier available to access this population - and, to date, no complete directory of firewood producers exists in the state. In fact, the West Virginia state government only has six registered producers on file (www.wv.gov). The Appalachian Hardwood Center identified only one registered firewood business and then an additional nine forest products companies selling firewood as a sideline to their business in their 2013 West Virginia Forest Products Industry Directory.

The second phase involved a two-part survey where first a telephone interview was used

to identify and establish contact with current producers, alert them to the study, and engage them in a five-minute survey eliciting basic business information; for willing participants, this was followed by a mailed questionnaire to solicit more detailed information. The third phase involved compiling and analyzing the results from these two surveys and using them to design outreach programs that would most benefit West Virginia producers.

\section{Phase I: Compiling a database of firewood producers (sampling frame)}

Beginning in November 2011, telephone numbers were collected from a variety of sources including the internet, Yellow Pages ${ }^{\mathrm{TM}}$, traders' magazines and public postings. Foresters from the West Virginia Division of Forestry were also recruited to collect telephone numbers during their daily field excursions, as their experience of firewood producers was that 
they tended to advertise mostly by local postings using fliers or signs on trees, poles, or in local stores. All telephone numbers advertising firewood for sale in the state of West Virginia were considered for the sample and were recorded along with any accompanying contact or product information provided. Tri-state (WV-VA-MD generally) were considered as part of the survey sample, but ads that explicitly described a downed tree(s) to be removed or free firewood were not considered.

Existing literature attests to evidence of loggers and tree surgeons participating in the firewood industry by selling firewood as a sideline to their main businesses (Evans \& Parker 1987, Driscoll et al. 2000, MacIntyre 2007, Seeland 2007). Because of this, some tree care $(\mathrm{n}=$ 16) and logging $(n=3)$ companies were deliberately included in the population for this project to see if any were engaging in such activities in the state of West Virginia; others were included organically as phone numbers were collected because they advertised firewood for sale independent of their main business.

Telephone numbers were also provided from a list that had been compiled between October 2008 and August 2009 by two Americorps volunteers working for the Appalachian Forest Heritage Area; one was based in Randolph County out of Elkins, West Virginia, and the other in Webster County out of Webster Springs, West Virginia. Five people contacted the WV Friends of Firewood personally after reading about the project in local publications. Snowball sampling added an additional 14 contacts that were provided by producers who participated in the telephone interview. Telephone numbers were collected on a weekly basis until January 2013. A total of 429 telephone numbers were collected, including four alternate numbers for the same contacts from different ads.

\section{Phase II: Two-part Survey Engagement Strategy}

A two-part survey was utilized to solicit information from various firewood producers throughout West Virginia. The two survey methods used were designed to elucidate components of the firewood value chain in the state and determine the business, safety and wood hygiene practices of these producers. A telephone interview and mailed questionnaire were used to elicit information from firewood producers concerning the scope of the firewood industry in West Virginia. Please see Appendix D for the telephone interview script, Appendix E for an example 
of the mailed questionnaire cover letter and Appendix F for the questionnaire. These instruments were intended to be used in sequential order. Initially, a telephone interview was carried out to identify individuals producing firewood and to engage them in the project. The idea behind the interview was to establish first contact and to be friendly and welcoming - a "foot-in-the-door" approach designed to engage as many members from this notoriously undocumented population as possible (Reingen \& Kernan 1977). Following the telephone interview, the mail questionnaire was used to gather detailed information from willing respondents who had given their postal addresses.

\section{Telephone Interview Design}

The WV Friends of Firewood 2012 Firewood Producer telephone interview design reflected the desire for a comfortable, conversational tone and a quick interview lasting no longer than 5-10 minutes. The objective of the telephone interview was to establish first contact and determine whether the respondent currently or had ever contributed to the firewood community. Ultimately, the telephone interviewer (there were two interviewers in this study, as will be explained later) attempted to convince the firewood producer to take part in a more in-depth mail questionnaire, so it was vital to establish some level of trust and collaboration during this stage.

Respondents were assured of complete confidentiality by the telephone interviewer and asked if they would like to proceed before beginning the interview, as required by the West Virginia University Institutional Review Board. Respondents were then asked a series of questions relating to customer base, types of units sold, delivery practices and recent injuries, and were also asked to gauge their interest in certain educational topics for workshops that could benefit their businesses (see telephone interview script in Appendix D). Each respondent's answers were recorded in a spreadsheet under a code assigned to each telephone number, to protect respondent confidentiality.

Preliminary telephone interviews were conducted between June 27 and July 2, 2012, with three known firewood producers who were able to offer feedback on the questionnaire design. A final telephone interview script and mail questionnaire were submitted to the West Virginia University Institutional Review Board and approved on September 15, 2012. An internet 
telephone account was created through Skype and a year-long subscription with a voicemail and callback number was purchased so that landlines could be called.

Telephone interviews began on October 3, 2012. These were rolling interviews conducted as new telephone numbers were collected. Telephone calls were made between 11 am-9pm Monday through Friday by two separate interviewers, one using the Skype account from a home office and one calling from an office landline. Basic telephone interview structure and etiquette were maintained and respondents were assured of confidentiality, but telephone calls proceeded organically on a case-by-case basis in order to allow interviewers flexibility in engaging as many respondents as possible. One way that this was accomplished was by offering respondents that seemed hesitant to be interviewed on the telephone the opportunity to participate in the mail questionnaire instead, which could be delivered either via USPS or via email for those respondents hesitant to give out their home address. Telephone interviews were completed on March 8, 2013.

\section{Mail-based Questionnaire Design}

Mail questionnaire design reflected a desire to supplement information acquired during the telephone interview, and delved into personal protective equipment use, descriptions of recent injuries, pricing, personal satisfaction and business history. It employed a combination of questions that were open-ended, close-ended with ordered response choices, close-ended with unordered response choices, partially close-ended with unordered response choices, and questions with Likert-scale response choices, after Salant and Dillman (1994). A draft pilot questionnaire was disbursed to various experts, including an occupational safety research scientist, a state forest entomologist and two firewood producers, for feedback on question design and topics covered.

Mail questionnaires were sent out on October 2, 2012, to the original sample of known firewood producers who had helped design the telephone interview. First questionnaires were mailed to telephone respondents on October 5, 2012. A modified Dillman (1994) method was employed with this questionnaire. Mailed questionnaires were sent as permission to do so was granted by telephone interviewees; all initial questionnaires were sent out within two weeks of the original contact telephone call. Reminder postcards were mailed one month after the first 
round of mailed questionnaires were sent to the first set of producers; thereafter the method was altered and these reminder postcards were sent to respondents two weeks after the original mail questionnaire was sent. A second reminder postcard was mailed or emailed to each respondent one month after the questionnaire was sent, and a second questionnaire sent two weeks after that.

Respondents who received the mailed questionnaire by either USPS or email were delivered identical packages consisting of a personalized cover letter on West Virginia University letterhead, cover page with instructions, and questionnaire. Each questionnaire was labeled with the code number assigned to the respondent during the telephone interview, to allow for comparison between the telephone interview and written questionnaire, while also protecting the confidentiality of each respondent. The personalized cover letter notified the respondent as to the purpose of the project. Email reminders consisted of an email message and attached postcard image, and were sent out on the same schedule as mailed postcards: two weeks and one month after the original questionnaire was emailed. As questionnaires were sent back, all data were entered in a spreadsheet; for the sake of analysis, any questionnaires received after July 15 , 2013, were not included in the results.

\section{General note about survey design}

This survey was designed to be two-part, with the telephone interview serving as a "foot in the door," both used to identify eligible respondents and establish a working relationship. Written questionnaires were intended to be mailed within a week of the telephone interview, so that the project would still be fresh in the mind of the respondent, making them more likely to respond. The interview and questionnaire had overlap in the kinds of questions asked so that checks of response reliability could be made between the two survey instruments. The telephone interview, although providing crucial information in its own right, paved the way to a more indepth examination of the history, practices and motivations of firewood producers, solicited by the mail questionnaire.

However, it was expected that not every firewood producer would be willing to take part in both surveys, so this overlap in questions allowed estimations of missing data due to a respondent completing only one of the survey instruments; this allowed for a more complete generalization in fulfilling the purpose of "painting a picture" of the entire firewood industry in 
the state. The two surveys were designed to be complimentary, with the mail questionnaire supplementing the basic information acquired from the telephone interviews. The telephone interview would be instrumental in establishing the database of and engaging current producers, while the mail questionnaire would delve into their knowledge gaps, receptiveness to education, background/history and detailed information on marketing, safety and wood hygiene practices.

Responses were coded on whether the telephone number was a positive contact (completed one or both surveys), a refusal, a producer refusing because they are no longer selling, a wrong number (a telephone number that did not belong to a producer), a "one-timer" (those who only had a downed tree(s) or an excess of personal use firewood one or more times), a non-contact (meaning that no contact was made after at least two call attempts), a disconnect (out-of-service telephone numbers), a duplicate (alternate telephone numbers, with each instance including a note as to the original contact entry in the database), or a producer that does not sell in West Virginia. Positive contacts were sub-divided into those producers who were only willing to participate in the telephone interview, those who were only willing to participate in the mail questionnaire, and those who were willing to participate in both surveys. A list of these response codes can be found in Table 14 of Appendix A.

\section{Phase III: Data Manipulation and Analysis}

\section{Response and Cooperation Rates}

The response and cooperation rates for the telephone interview and mail questionnaire were calculated using the following method (AAPOR 2008):

Telephone interview response rate $=($ Complete + Partials $) /($ Complete + Partials + Refusals + No-contacts);

Mail questionnaire response rate $=($ Complete + Partials $) /($ Complete + Partials + Refusals + Not Returned);

Cooperation rate for both surveys $=($ Complete + Partials $) /($ Complete + Partials + Refusals $)$. 


\section{Coding}

The data collected from the telephone interviews and mail questionnaires required some manipulation and coding before analysis could begin, because many respondents interpreted certain questions very differently. The complete telephone interview script and questionnaire can be viewed in Appendices D and F, respectively, and coding for open-ended responses is in Appendix A. For instance, examples provided as explanation for "other" categories had to be coded.

For the mail questionnaire, Likert-scale questions using a scale of 1-4 of agreement were broken into two brackets of 1 and 2 being "disagree" and 3 and 4 being "agree." Questions 34A$\mathrm{D}$, which pertained to producer opinions of invasive species, were treated similarly, but since this question was on a scale of 1-5 with 3 being "I don't know," respondents who answered "I don't know" were treated as a non-response for that particular question while 1 and 2 were once again treated as "disagree" and 3 and 4 as "agree." Questions 35A-H pertaining to Best Management Practices was broken down similar to a Likert scale of 1-4, with 1 and 2 being "difficult" and 3 and 4 being "easy." Questions 51A-H of the mail questionnaire and Questions 6A-F of the telephone interview pertaining to the likelihood of respondents attending various classes were also treated similarly, with 1 and 2 being "unlikely" and 3 and 4 being "likely."

Other responses, such as delivery charges (Question 18 of the mail questionnaire) required more interpretation and were coded according to whether producers implied a flat (or by load) rate, a rate based on mileage, or that the charge was included in the price (Question 21 of the mail questionnaire relating to discount for customer pick-up was coded similarly). In order to determine last year's volumes sold by mail questionnaire respondents in cords (Question 20), it was assumed that when a producer responded in pickup loads, they were referring to the pickup dimensions provided in Question 19 regarding volume units used; if two truck dimensions were provided, they were averaged; if no dimensions were provided in Question 19, then a standard pickup size was created by averaging all 6-foot bed dimensions provided by other producers.

For Question 42, mail questionnaire respondents were asked to give the time of day that they typically harvest or cut their raw wood; this particular question was misinterpreted by many 
respondents, who would give intervals of time. Because of this, it was determined that the responses from this question should be divided up into intervals of six hours (6:00 a.m.-12:00 p.m., 12:01 p.m.-6:00 p.m.); the last interval was 12 hours (6:01 p.m.-5:59 a.m.) due to the few number of respondents indicating that they harvested during these hours. Codes were then generated from combinations of these intervals (Table 22 of Appendix A). Question 47 of the mail questionnaire and Question 5 of the telephone interview were open-ended and asked producers to describe their most common injury; responses were coded according to location on the body and type of injury, each of which had its own code that was combined into a two-digit code (Table 23 of Appendix A).

As for the description of any severe injuries experienced within the last 12 months that required more than first aid (Questions 50 and 50A-C of the mail questionnaire), responses were broken down into location of injury, type of injury and the activity at the time of the injury. Originally Questions 50A-C asked about the affected body part, how the injury occurred and what the respondent was doing when the injury occurred, respectively. The latter two questions were answered similarly by respondents, so it was deemed more appropriate to organize the answers as seen in Table 24 of Appendix A. Also, a new category of "retired" had to be coded for yearly income (Question 60).

\section{Statistical Analyses}

Summary statistics were calculated and tables and graphs were created where appropriate for every answer from both the telephone interview and mail questionnaire. The range and average of continuous variables (open-ended questions concerning the maximum number of miles respondents are willing to travel to deliver, percentage of personal individual income earned from selling firewood, number of years respondents plan to continue selling firewood, etc.) were calculated. These continuous variables were also broken into categories so that answers could be grouped for the purposes of statistical summary and graphical representation. This bracketing was also used for Fisher's Exact and McNemar's Test analyses that could be compared with t-test and/or One-way Analysis of Variance (ANOVA) results for the following reliability and sub-group analyses. 


\section{Reliability Analysis}

In order to test the reliability of the instruments used, corresponding results from those respondents who participated in both the telephone interview and mail questionnaire were compared using inferential statistics. Results from telephone interview-only respondents and mail questionnaire results from respondents who participated in both surveys were also compared for reliability. Fisher's Exact Test was used to compare categorical responses (such as customer base and units used) from the telephone interview-only respondents and mail questionnaire respondents; this was chosen over $\chi^{2}$ because in many instances more than $20 \%$ of the expected cell frequencies were less than five. McNemar's test was used to compare those corresponding answers from the respondents who participated in both surveys. Paired t-tests (paired two sample for means) were used for continuous variables (such as miles traveled to deliver and percent income earned from firewood) for corresponding results from respondents who participated in both surveys, while paired two-sample t-tests (assuming unequal variances) were used to compare results from telephone interview-only respondents to mail questionnaire results of respondents who participated in both surveys; $p<0.1$ was considered significant. Oneway ANOVA were also calculated for each continuous variable for comparison with t-test results; $\mathrm{p}<0.1$ was considered significant for these analyses as well.

The six questions of interest from the telephone interview were broken down into 27 questions, since respondents were asked to answer yes or no to whether they sold to certain customer types in Question 1 and also to rate their interest in six different workshop topics for Question 6. Examples provided for "other" categories were not considered in these reliability analyses because the small number and high variability of responses made them difficult to compare statistically; instead, these were considered on a yes/no basis as well. General class interest (respondents "somewhat likely" or "very likely" to attend at least three of the six workshop topics) was analyzed for reliability as well. Summary statistics were calculated for the variables from the two different sets of reliability analyses.

\section{Analysis of Sub-groups}

In an effort to determine whether there are certain producers who might be more interested in furthering their education and developing their businesses, several sub-groups were 
also analyzed to see if mail respondents answered certain questions significantly differently depending on whether or not they were willing to attain a Community Firewood Dealer certification (Question 36), whether they consider firewood production a hobby (if they circled a three or four on the Likert scale for Question 25A), whether they were between 18 and 40 years of age or over the age of 40 (Question 56), whether or not they mentioned that they began selling firewood for supplemental income (even if multiple answers were given for Question 2), and whether or not they had a general interest in classes ("somewhat likely" or "very likely" to attend at least four class topics from Question 51) (Table 34 of Appendix C). Respondent age groups (Question 56) were divided thusly because there were an equal number of respondents in each age group, and the largest age group was from 30 to 40 years (38\%).

Every single variable that was examined from the total sample was also examined for each sub-group. The responses from various questions were analyzed to statistically compare these respective sub-groups using Fisher's Exact Test for categorical variables (e.g., responses from questions such as opinions on firewood production and how invasive species affect their business and forest health, advertisement methods, PPE usage, etc.) and unpaired t-tests assuming unequal variances for continuous variables (such as volumes sold, miles traveled to harvest and deliver, percent income earned from firewood, etc.); $p<0.1$ was considered significant. Fisher's Exact Test was again chosen over $\chi^{2}$ because of the small sample size: in many instances more than $20 \%$ of the expected cell frequencies were less than five. One-way ANOVA were also calculated for each continuous variable for comparison with t-test results; $\mathrm{p}<$ 0.1 was considered significant for these analyses as well. Summary statistics were also calculated for the variables comparing each subgroup. 


\section{CHAPTER IV: Results}

\section{Survey Response and Cooperation Rates}

Initially, 429 separate telephone numbers were collected for the telephone interview. Of these, four were from separate ads where a producer already on the contact list used an alternate number (these were discovered one by one as the interviews were conducted), $26(6 \%)$ belonged to out-of-state producers with no West Virginia customers, 50 (11.7\%) were disconnected, 26 (6\%) belonged to individuals who indicated explicitly that they had only sold once or not regularly and 37 (8.6\%) numbers belonged to people indicating that they had never sold firewood.

In total there were 286 eligible contacts. Fifty-three (18.5\%) refused to participate in the telephone interview; 18 of these respondents (6.3\%) indicated explicitly that they were no longer selling firewood (four specifically said they had not sold firewood "in years") and so did not want to participate; two more respondents refused the telephone interview but agreed to complete the mail questionnaire. One hundred twelve contacts (39.2\%) did not respond after two telephone calls. Of the 286 eligible contacts, 102 (35.7\%) participated in the telephone interview, yielding a cooperation rate of $58.6 \%$.

Eighty telephone interview respondents (78.4\%) originally agreed to complete the mail questionnaire. Of these, 44 (55\%) questionnaires were returned; since only 42 were considered complete (one was a duplicate and one was a refusal, despite the initial permission given to send this to the telephone interview respondent), the response rate was $52.5 \%$ and the cooperation rate was $95.5 \%$. Questionnaires were considered complete if at least $60 \%$, or 40 questions, were answered. Many respondents answered only those questions they were comfortable answering, so the response rate of each question differs (see Table 16 of Appendix A for a list of number of responses for each individual question). The following results therefore contain the relative frequencies of each response which were based solely on answered questions; we are simply describing our sample. 


\section{Telephone Interview Results}

\section{Business Practices}

Most telephone interview respondents (99\%) identified private individuals or homeowners as their primary customers; the next largest customer base was public or private parks or campgrounds (15\%). Eighty-eight percent of telephone respondents indicated that they deliver firewood to their customers, with the maximum distance that they are willing to travel ranging from four to 300 miles; the average was 37 miles. The largest group of respondents (40\%) is willing to travel 25 to 49 miles (Figure 2). The majority of interview respondents' customers is located within the state of West Virginia (average 91.3\%). Regarding volume units used to market their firewood, $91 \%$ sell by the truckload, and reported an average truck volume of 148.9 cubic feet. Another $43 \%$ of telephone respondents indicated that they sold by the cord. Interview respondents reported earning a range of personal individual income from selling firewood of zero to $100 \%$, with an average of $13.5 \%$. Over half reported earning less than $10 \%$ of their personal individual income from selling firewood (Figure 3).

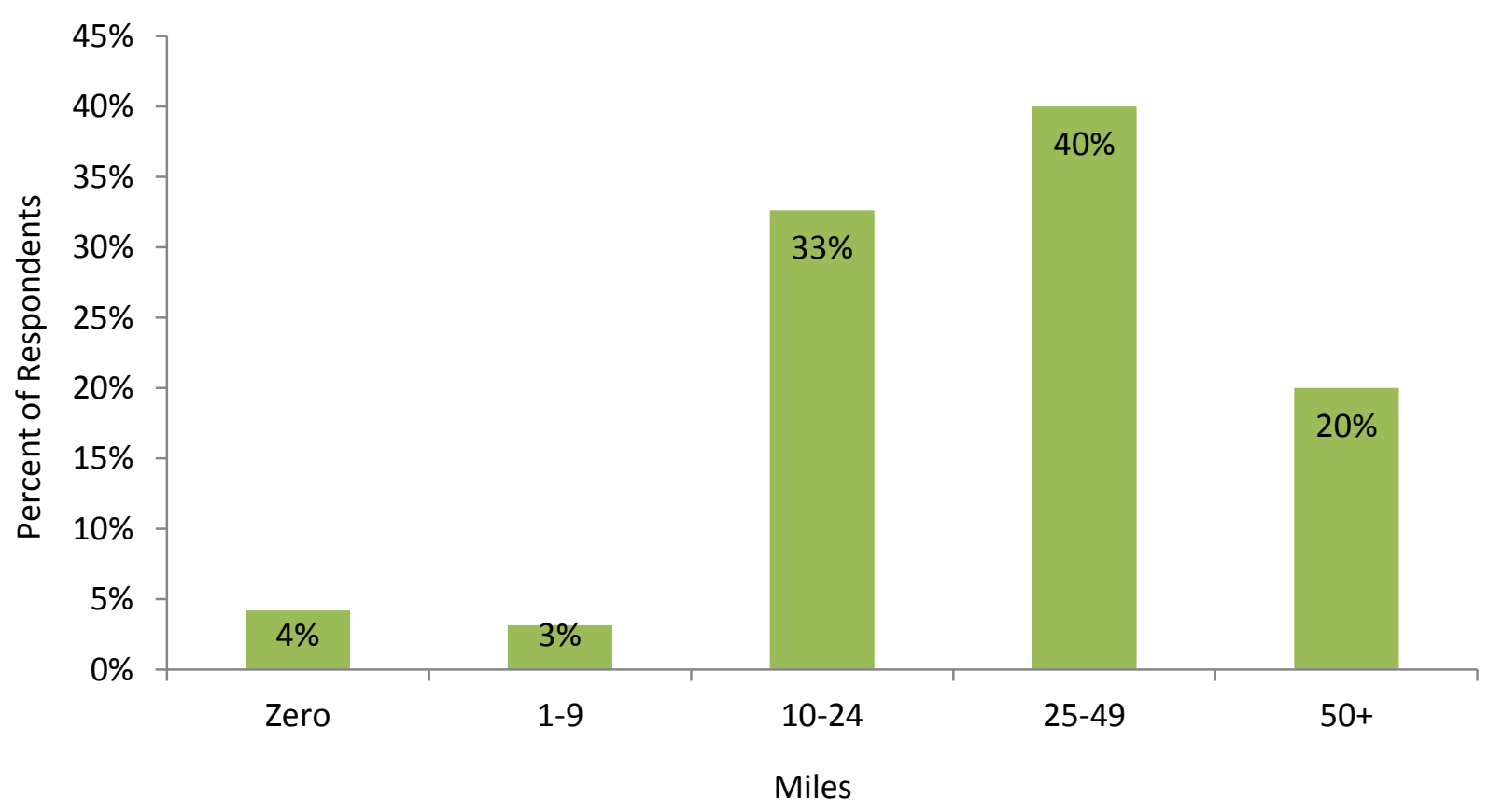

Figure 2. Maximum miles telephone respondents are willing to travel to deliver firewood to their customers. 


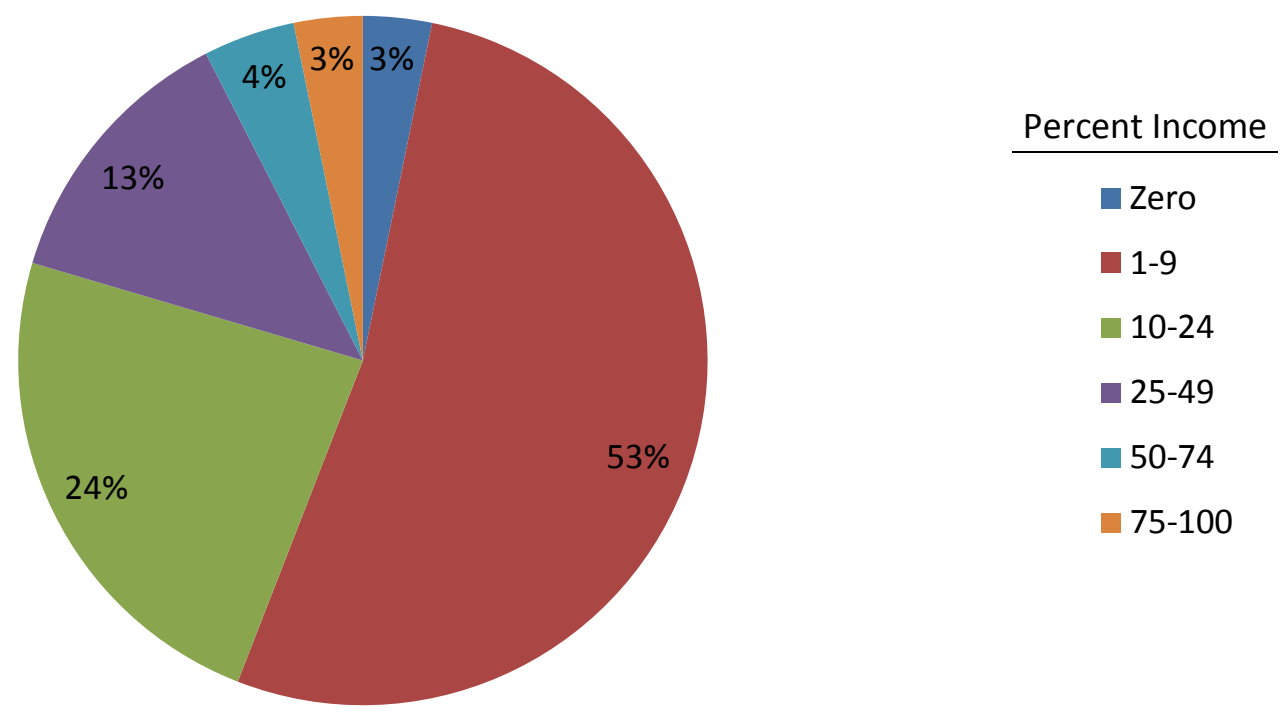

Figure 3. Percent of personal individual income earned by telephone interview respondents from selling firewood (93 responses).

\section{Safety Practices}

Over a quarter $(27 \%)$ of respondents indicated that smashing, bruising or pinching of the hand was their most common injury. Twenty-three percent of telephone interview respondents reported that they had never experienced an injury. Twelve percent reported a sore or aching back (Table 7). 
Table 7. Most common injuries reported by telephone interview respondents.

\begin{tabular}{lc}
\hline Most Common Injury (Location/Type) & Percent of All Respondents \\
\hline Hands/Smashing, bruising or pinching & $27 \%$ \\
No injury & $23 \%$ \\
Shoulder or back/Sore or aching & $12 \%$ \\
Unspecified/Splinters or blisters & $10 \%$ \\
Unspecified/Sore or aching & $7 \%$ \\
Unspecified/Smashing, bruising or pinching & $6 \%$ \\
Unspecified/Lacerations, cuts or scrapes & $4 \%$ \\
Feet/Smashing, bruising or pinching & $4 \%$ \\
Shoulder or Back/Muscular (tearing of tendons/ligaments, & $3 \%$ \\
beyond sore) & $3 \%$ \\
Hands/Bone breaks & $2 \%$ \\
Hands/Lacerations, cuts or scrapes & $2 \%$ \\
Hands/Splinters or blisters & $2 \%$ \\
Legs/Lacerations, cuts or scrapes & $2 \%$ \\
Feet/Bone breaks & $2 \%$ \\
Unspecified/Muscular (tearing of tendons/ligaments, & $1 \%$ \\
beyond sore) & $1 \%$ \\
Legs/Smashing, bruising or pinching & \\
\hline
\end{tabular}

\section{Educational Topics of Interest}

Thirty-three percent of telephone interview respondents indicated that they would be "somewhat likely" or "very likely" to attend at least half of the classes described. Over half $(58 \%)$ of telephone interview respondents were interested in a workshop on pest and disease identification. The classes for which telephone interview respondents had the least interest were taxes (32\%) and accounting (31\%) (Figure 4). Thirty-one telephone interview respondents had ideas for other class topics: thirty-five percent of these respondents suggested a class on volume measurements and 16\% suggested a class on tree/wood identification. 


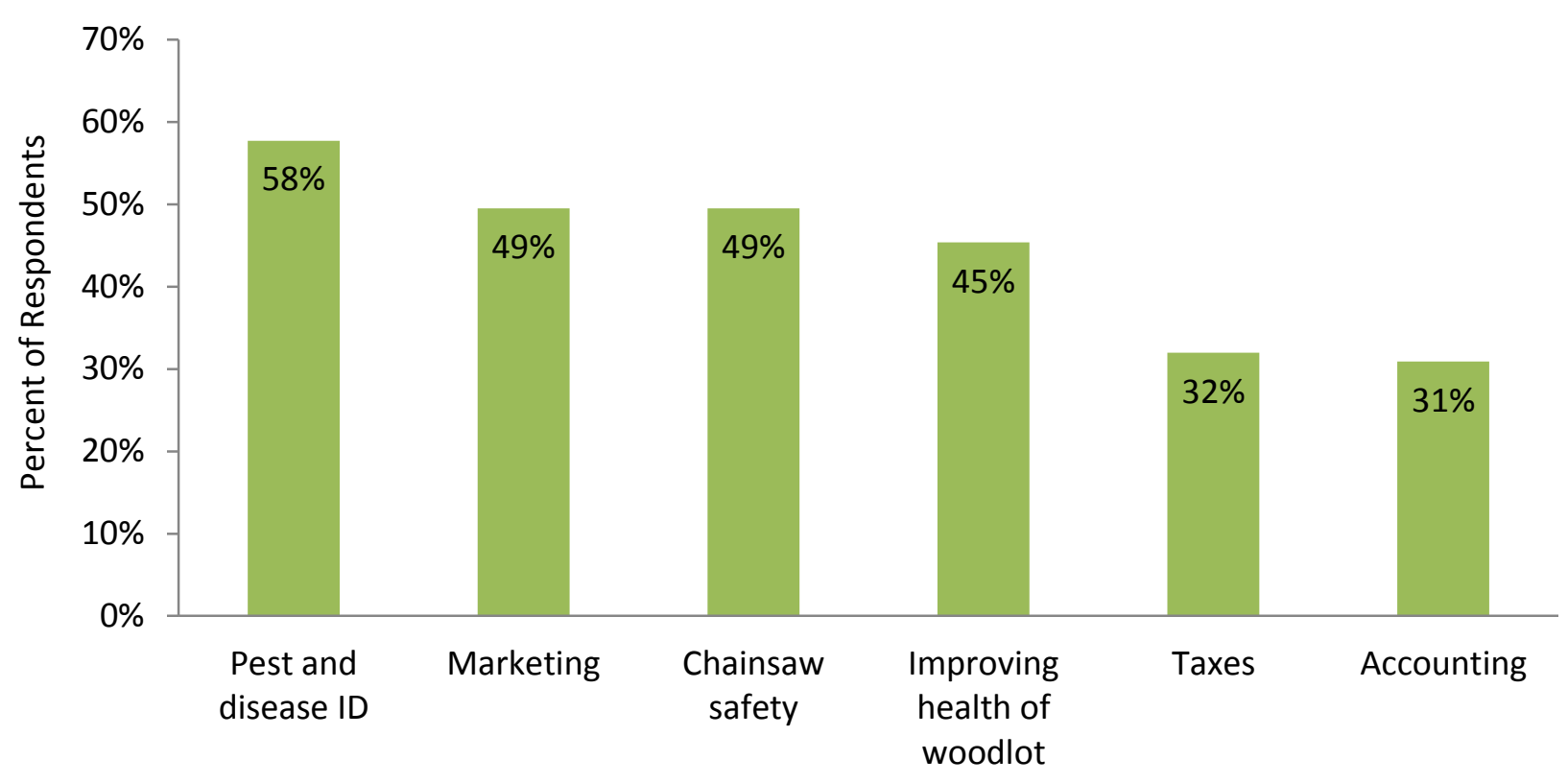

Class Topic

Figure 4. Classes that telephone interview respondents are "somewhat likely" or "very likely" to attend.

\section{Mail Questionnaire Results}

\section{Demographics}

The majority of questionnaire respondents (98\%) were male; the largest age group was between 30-40 years of age (38\%), and the second largest 50-60 years (19\%). Most questionnaire respondents were high school graduates (32\%), while 15\% indicated that they had some college education and 34\% indicated a post-secondary education. Sixty-eight percent of respondents reported yearly earnings below $\$ 45,000$, seventeen percent reported earnings between $\$ 45,001-90,000$, and eleven percent reported earning more than $\$ 90,000$. Questionnaire respondents represented 18 West Virginia counties, with Monongalia County representing the highest percentage (18\%). Two more mail respondents were from Virginia counties, but indicated that they sold at least some of their firewood in West Virginia. For a list of represented counties, please see Table 18 of Appendix A. 


\section{Experience, Background and Motivations}

Mail questionnaire respondents have been selling firewood anywhere from zero to 54 years. Over half $(51 \%)$ of questionnaire respondents indicated that they had been selling firewood for zero to five years; the second-highest experience level was more than 10 years (37\%); the average time in business was 11.9 years. The largest employment categories were professional (29\%) and general trade (20\%); many respondents provided more than one answer to this question. The largest category of involvement in the firewood industry was the need for supplemental income (49\%), followed by the need to get rid of green waste from land clearing/property maintenance (31\%), then need to sell excess personal use firewood $(23 \%)$ (Table 8). 
Table 8. Number of years mail questionnaire respondents have been selling firewood, their main employment category, and how they entered the firewood industry.

\begin{tabular}{lc}
\hline Years Selling Firewood & Percent of Responses \\
\hline $0-5$ & $51 \%$ \\
$6-9$ & $12 \%$ \\
$10+$ & $37 \%$ \\
\hline Employment Category & \\
\hline Professional & $29 \%$ \\
General Trade & $20 \%$ \\
Retired & $12 \%$ \\
Trade related to Forestry & $12 \%$ \\
Farmer & $10 \%$ \\
Non-skilled labor & $10 \%$ \\
Disabled & $7 \%$ \\
Nonprofessional supervisory & $5 \%$ \\
Unemployed & $5 \%$ \\
Other & $2 \%$ \\
\hline Origin of Involvement in Industry & $13 \%$ \\
\hline Supplemental income & $10 \%$ \\
Green waste from land clearing/property maintenance & $8 \%$ \\
Excess of personal use firewood & $31 \%$ \\
Green waste from landscaping or tree removal services & $23 \%$ \\
(sideline) & \\
Tradition & \\
Green waste from logging residue & \\
\hline Help family/friends/those in need & \\
\hline
\end{tabular}

Questionnaire respondents were asked a series of opinion questions related to firewood production and its role in forest health. The majority agreed that producing firewood gives them the opportunity to work outside in nature (98\%), that the activity is beneficial to their physical health (93\%), that firewood is an environmentally friendly source of energy (93\%), that selling firewood gives them the opportunity to meet interesting people (93\%) and that the activity is enjoyable to them. Eighty-one percent agreed that their business has a lot of local competition, but $76 \%$ also identified firewood as just a hobby and even fewer recognized it as a good source 
of income (68\% of 40 respondents) or as generating enough income to report to the I.R.S. (29\%). A majority of questionnaire respondents also agreed that the success of their business is directly related to forest health ( $83 \%$ of 36 respondents) and that the West Virginia firewood industry can help maintain forest health (97\% of 36 respondents), yet fewer agreed that invasive species are threatening the health of U.S. forests (79\% of 29 respondents) or that their business could be affected by changes in forest health in the near future (67\% of 33 respondents) (Figure 5). 
I like producing firewood because the activity allows me to be outside in nature

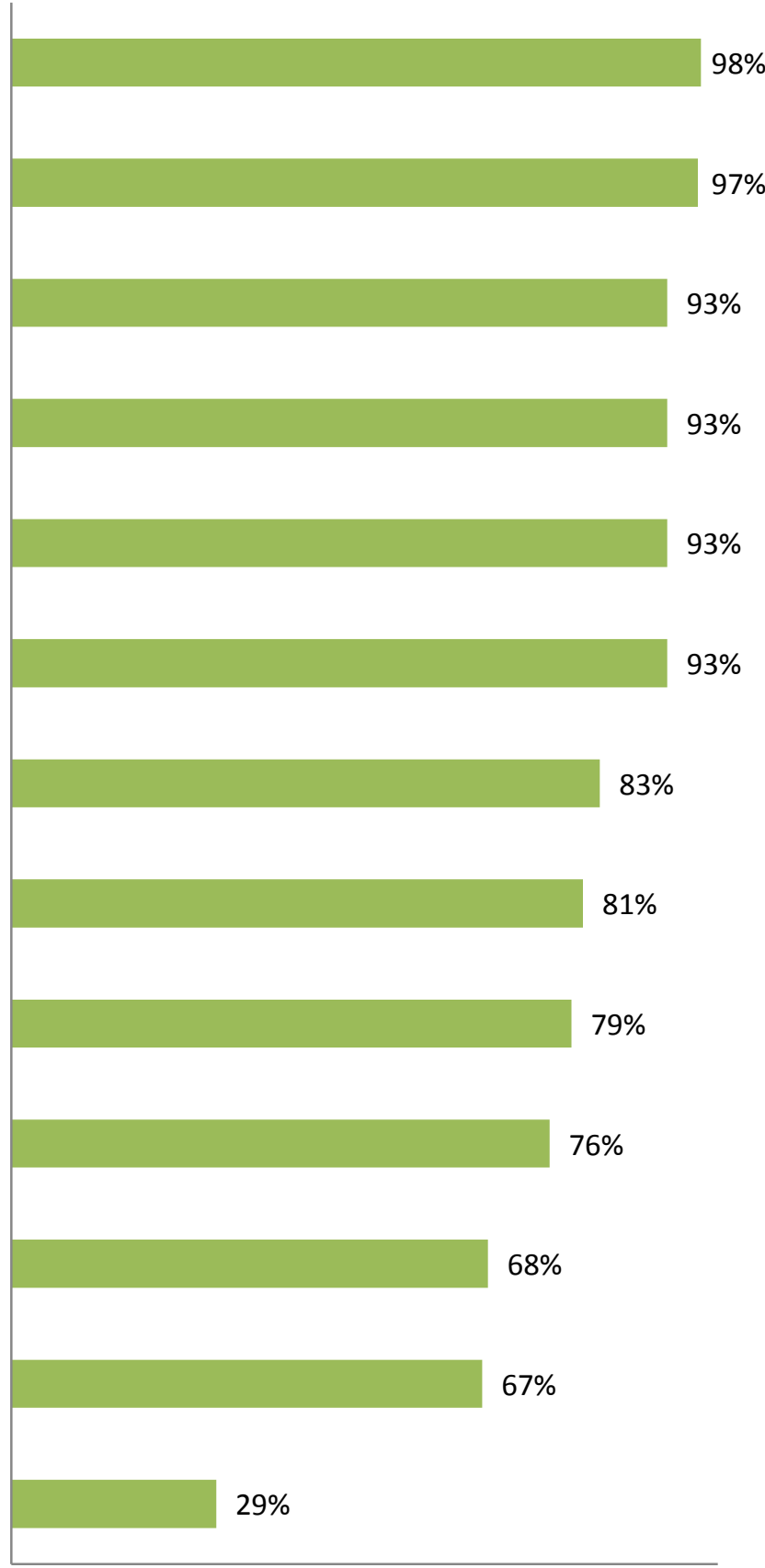

The WV firewood industry can help maintain healthy forests

Producing firewood is beneficial to my physical health

Firewood is an environmentally friendly source of energy

I meet interesting people as a result of selling firewood

Producing firewood is enjoyable for me

The success of my firewood business is directly related to healthy forests

My firewood business has a lot of competition where I live

Invasive species moved in firewood are threatening the health of US forests

My firewood business is a hobby; I sell the firewood that I do not use for myself

I like producing and selling firewood because it is a good source of income

My firewood business could be affected by the health of WV forests in the near future

My firewood business generates enough income for me to report to the IRS

0\% 10\% 20\% 30\% 40\% 50\% 60\% 70\% 80\% 90\% $100 \%$

Percent of Respondents Who Agree

Figure 5. Percent of mail questionnaire respondents who agree with various statements related to their motivations behind producing firewood, how they feel about their firewood business and the firewood industry's role in maintaining healthy West Virginia forests. 


\section{Business Practices}

The majority of mail questionnaire respondents identified their business categorization as "individual producer or dealer" (76\%); another 15\% percent of respondents identified themselves as loggers that sell firewood (Figure 6). Most firewood production (95\%) occurs in West Virginia, although there were two respondents (5\%) surveyed who operate out of Virginia. Sixty-one percent process at least half of their firewood personally. Ninety percent of mail questionnaire respondents deliver, traveling anywhere from five to 100 miles; the average maximum delivery distance that they reported was 30.4 miles (Figure 7). Close to half of questionnaire respondents ( $49 \%$ of 37 responses; respondents were allowed to provide more than one answer) charge for delivery with a flat rate per load; $32 \%$ charge by the mile; $30 \%$ do not charge for or else include delivery in the price of the load. Over half of the respondents (61\%) indicated that they offer a discount to customers who pick up their own firewood; forty percent of the 20 respondents who specified the kind of discount indicated that they offer a flat rate deduction.

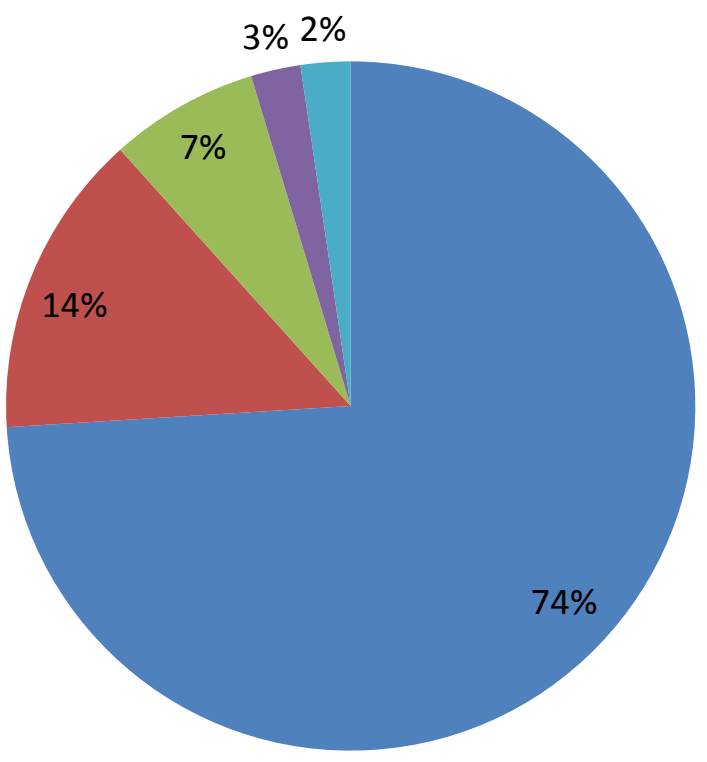

- Individual producer or dealer

Logger that sells bucked logs or firewood

Tree removal/care company that sells scrap wood or firewood

Other

Non-response

Figure 6. Mail questionnaire respondent business categorization. 
Mail questionnaire respondents travel anywhere from zero to 60 miles to harvest their raw wood, with an average of 16 miles (Figure 7). Sixty-nine percent of the raw wood obtained on average by questionnaire respondents is from their own or family woodlot; eighty-seven percent of their raw wood is obtained free of charge. Fifty-six percent of respondents obtain $100 \%$ of their raw wood from their own woodlot, while $15 \%$ obtain it from some kind of landclearing; five percent each harvest $100 \%$ from state lands or obtain $100 \%$ from performing tree care or land-clearing activities, and an additional $2 \%$ purchase $100 \%$ from loggers (Figure 8 ). Most respondents sell their firewood in either split or chunk form (88\%) or seasoned (86\%); one third (33\%) sell unseasoned or green wood (Figure 9). All questionnaire respondents identified private individuals or homeowners as their primary customers, while only four respondents indicated a secondary customer base (5\% campgrounds and 5\% other). Questionnaire respondents reported an average of $93 \%$ West Virginia customers, while the average number of repeat customers reported was $63 \%$. 


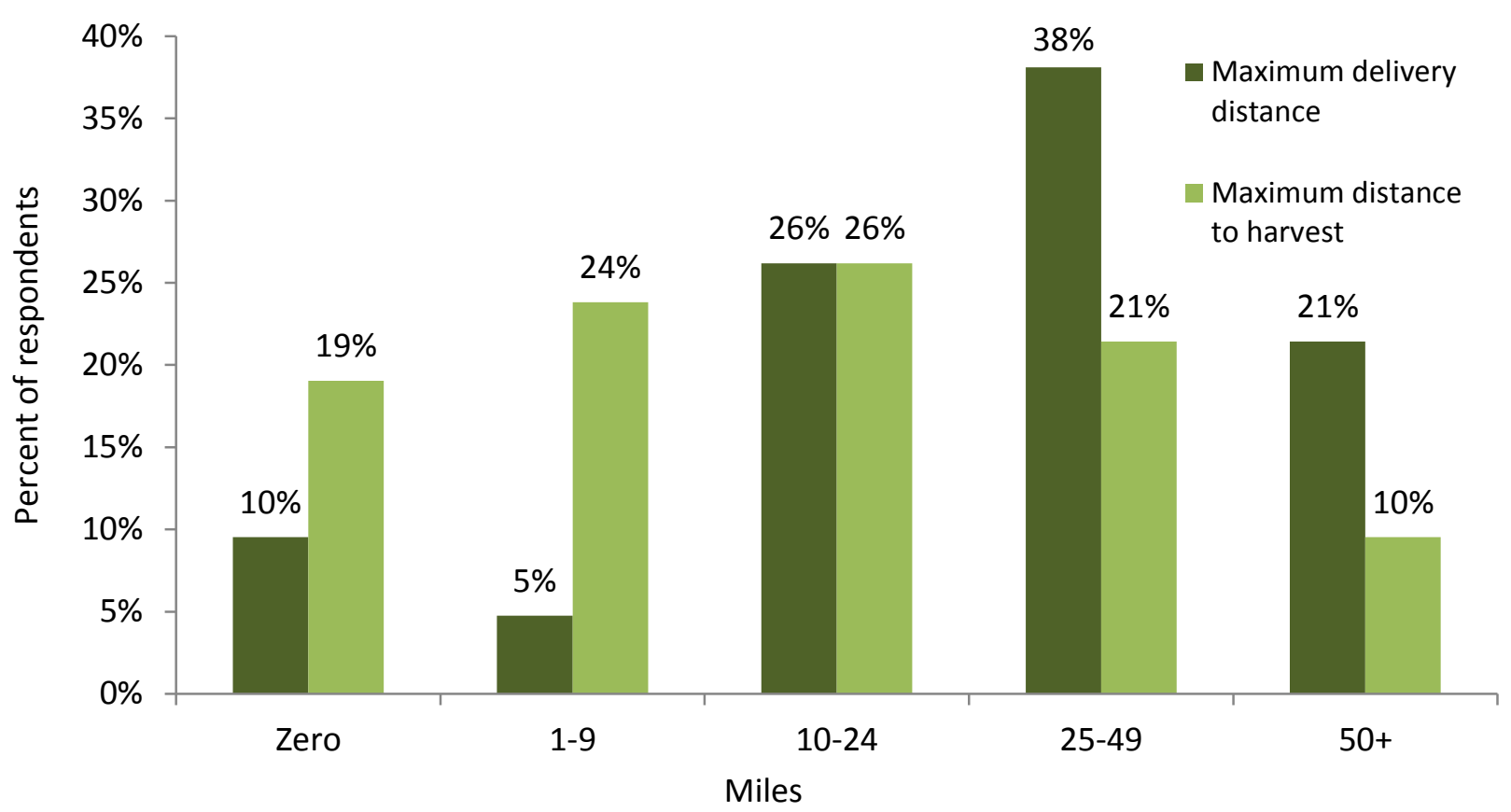

Figure 7. Maximum miles mail questionnaire respondents are willing to travel to harvest raw wood and deliver firewood to customers.

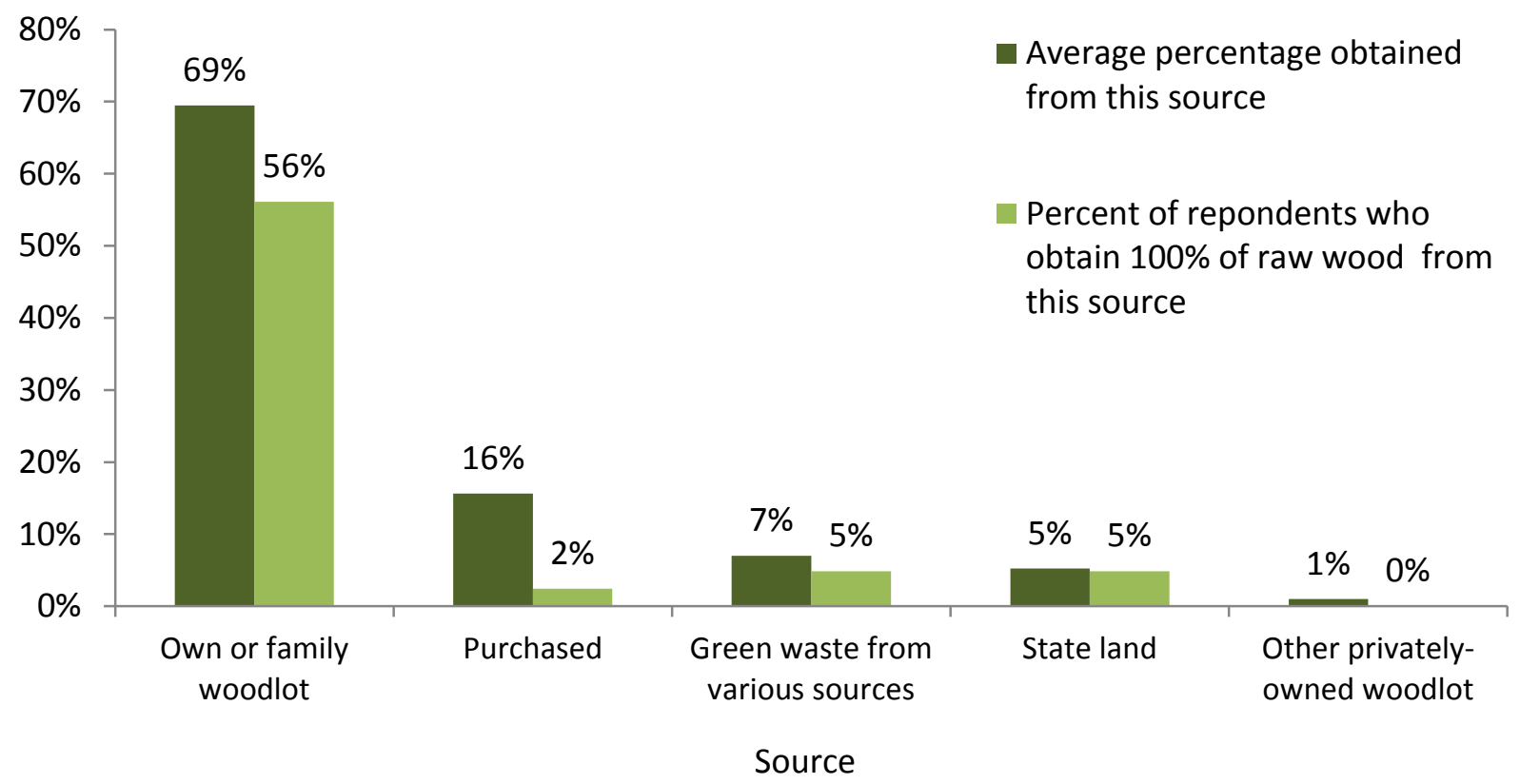

Figure 8. Sources of raw wood reported by mail questionnaire respondents. 


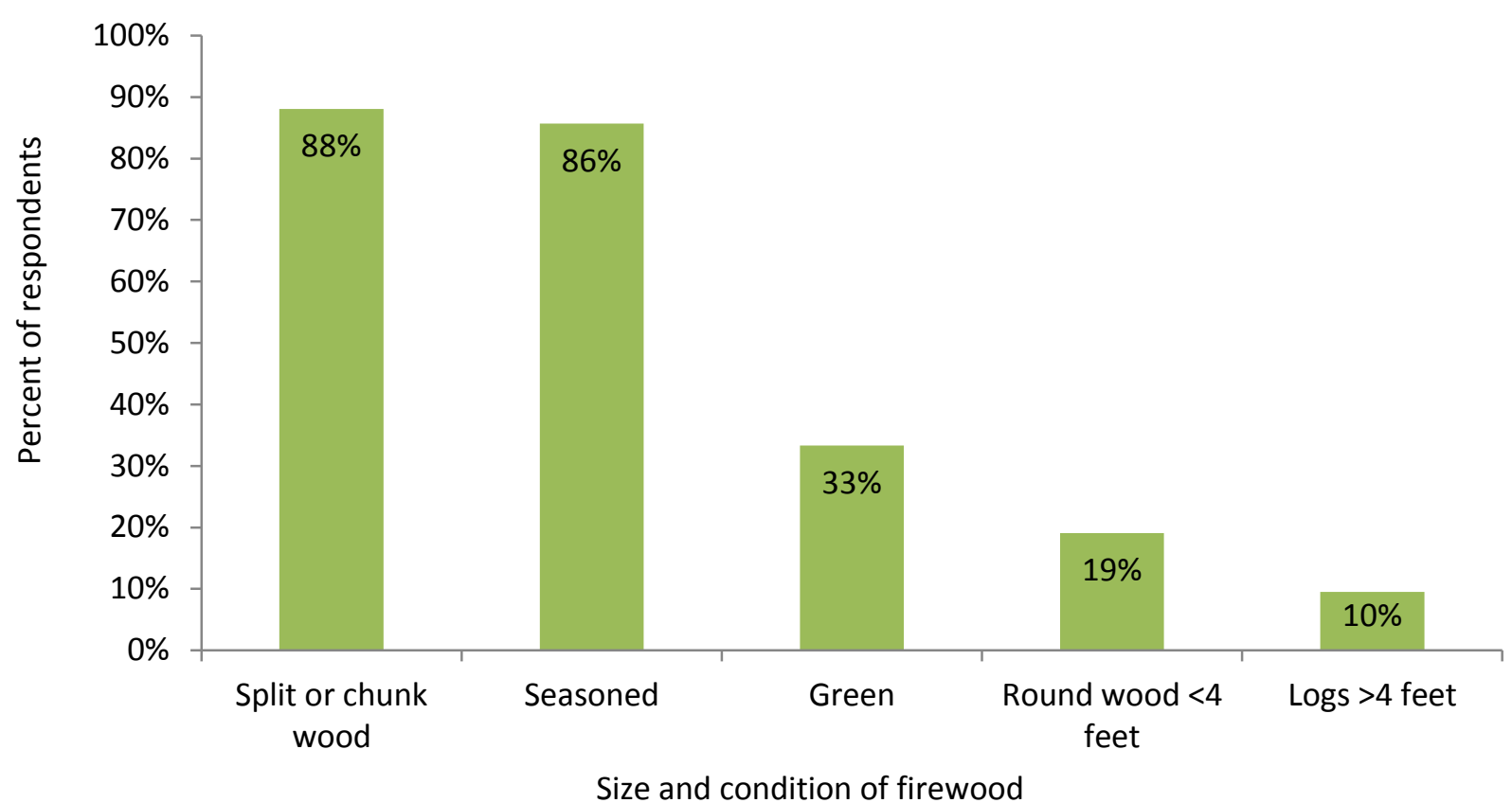

Figure 9. Size and condition of firewood sold by mail questionnaire respondents.

Three-quarters of mail questionnaire respondents indicated that they sell firewood by the truckload and reported an average truck volume of 142.3 cubic feet for an average price of $\$ 107.08$. Thirty percent of respondents indicated that they sold firewood by the cord for an average price of $\$ 121.67$; twenty-eight percent sold by the half cord for an average price of $\$ 157.27$. They sold anywhere from 0.6 to 500 cords last year, the average being 45.9 cords; over half of questionnaire respondents reported selling less than 10 cords last year (Figure 10). Sixtysix percent of questionnaire respondents indicated they utilize word of mouth to advertise their product, while $44 \%$ utilize the internet and $27 \%$ each utilize newspapers and fliers or business cards (Figure 11). It is interesting to note also that only six (43\%) of those respondents whose contact information had originally been collected from a newspaper or trader's magazine indicated that they used such sources, while 17 (88\%) of those respondents whose contact information had been found on Craigslist listed the internet as an advertisement method. 


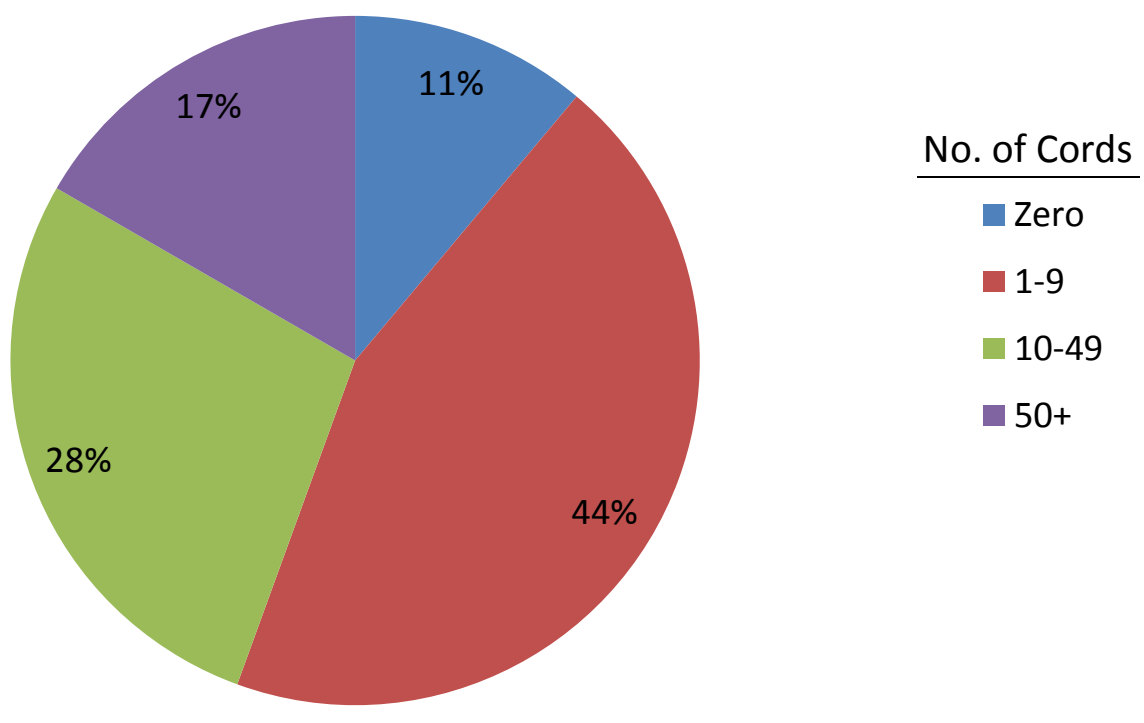

Figure 10. Number of cords sold last year by mail questionnaire respondents $(n=36)$.

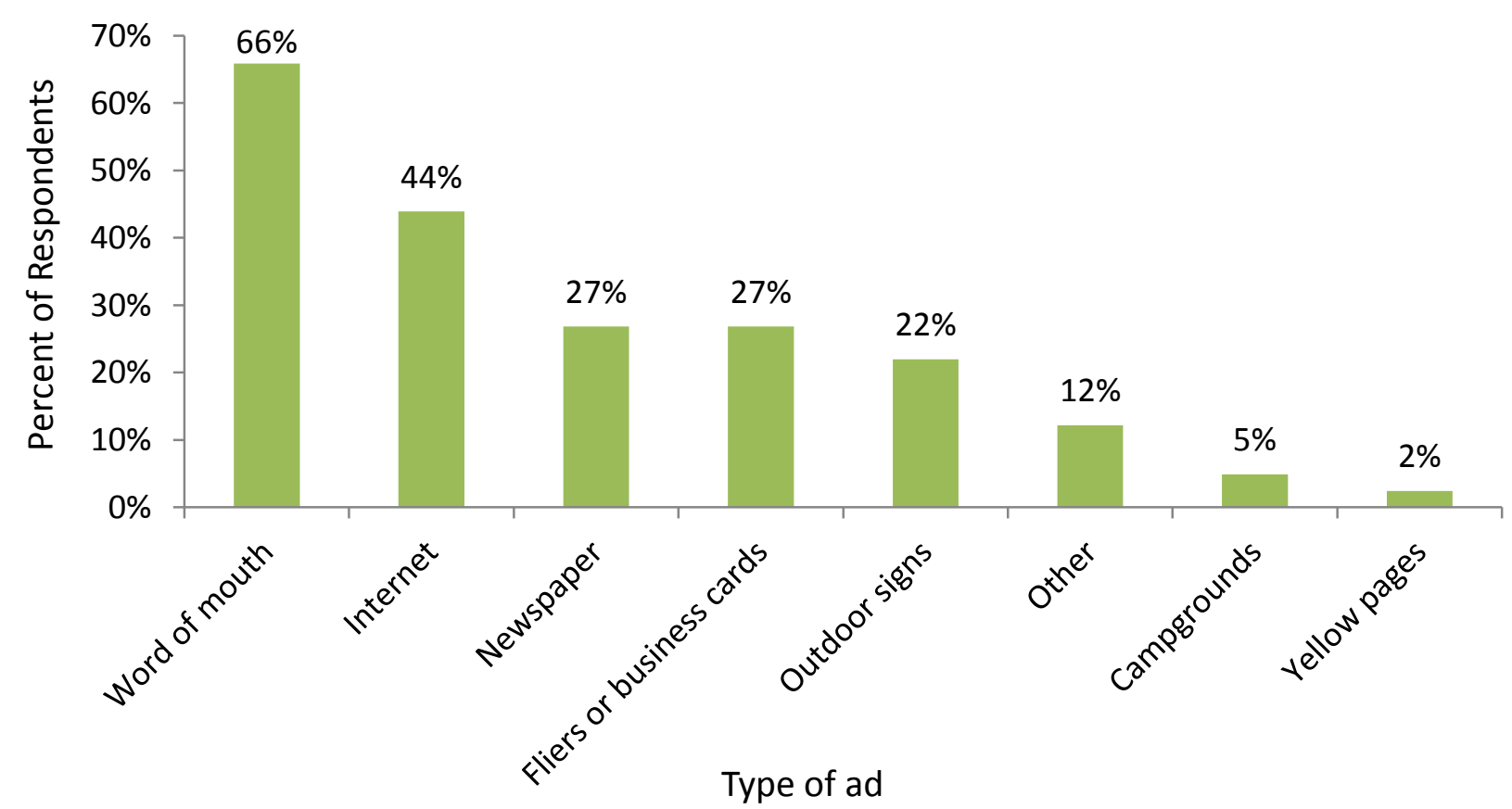

Figure 11. Types of ads utilized by mail questionnaire respondents to market their product.

Mail questionnaire respondents earn from zero to $100 \%$ of their personal individual income from selling firewood, with an average of $12.7 \%$. The great majority $(83 \%)$ of questionnaire respondents indicated that they earn less than $25 \%$ of their personal individual 
income from selling firewood (Figure 12). They plan to continue selling firewood for an additional zero to 55 years, or an average of 12.7 years; over half (56\%) indicated that they plan on selling firewood for an additional 10 years or more (Figure 13). 
Zero $\square$ 1-9 $\frac{\text { Percent income }}{10-24 \square 25-49 \square 50-74 \square \text { 75-100 }}$

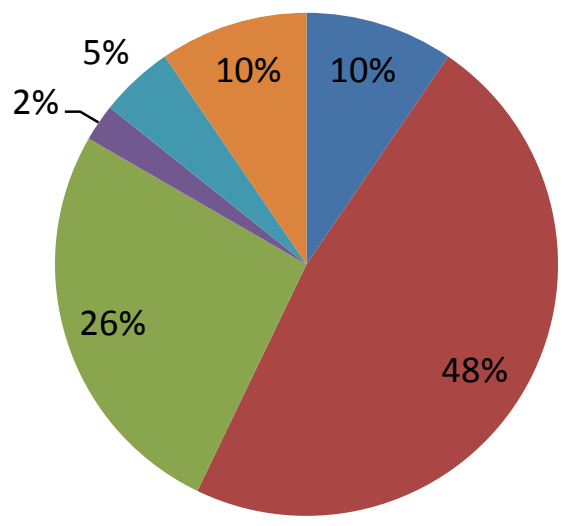

Figure 12. Percent of personal individual income earned by mail questionnaire respondents from selling firewood.

$$
\text { Zero } \frac{\text { No. of years }}{\square-4 \quad 5-9 \quad 10+}
$$

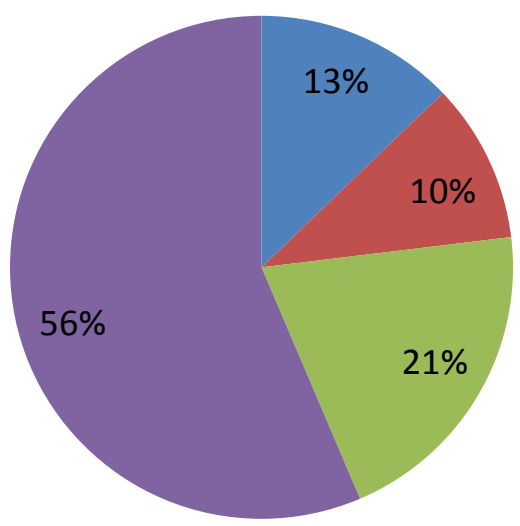

Figure 13. Number of years mail questionnaire respondents expect to continue producing firewood.

\section{Wood Hygiene and Best Management Practices for Firewood}

Ninety-eight percent of mail questionnaire respondents indicated that they season their firewood, yet 33\% indicated that they sold green wood in Question 22; they are seasoning anywhere from zero to 19.5 months. Close to half (45\%) season their firewood between 6-11 months, with an average of 8.4 months; only $29 \%$ reported seasoning their firewood for 12 months or longer. Only one respondent indicated that he de-barks his firewood; all other respondents reported that they do not sanitize their firewood in any other way. Questionnaire respondents indicated that an average of $50 \%$ of their raw wood comes from fallen timber, tree tops and downed trees or windfalls; an average of 23\% comes from diseased or less healthy trees and standing dead trees (Figure 14). 


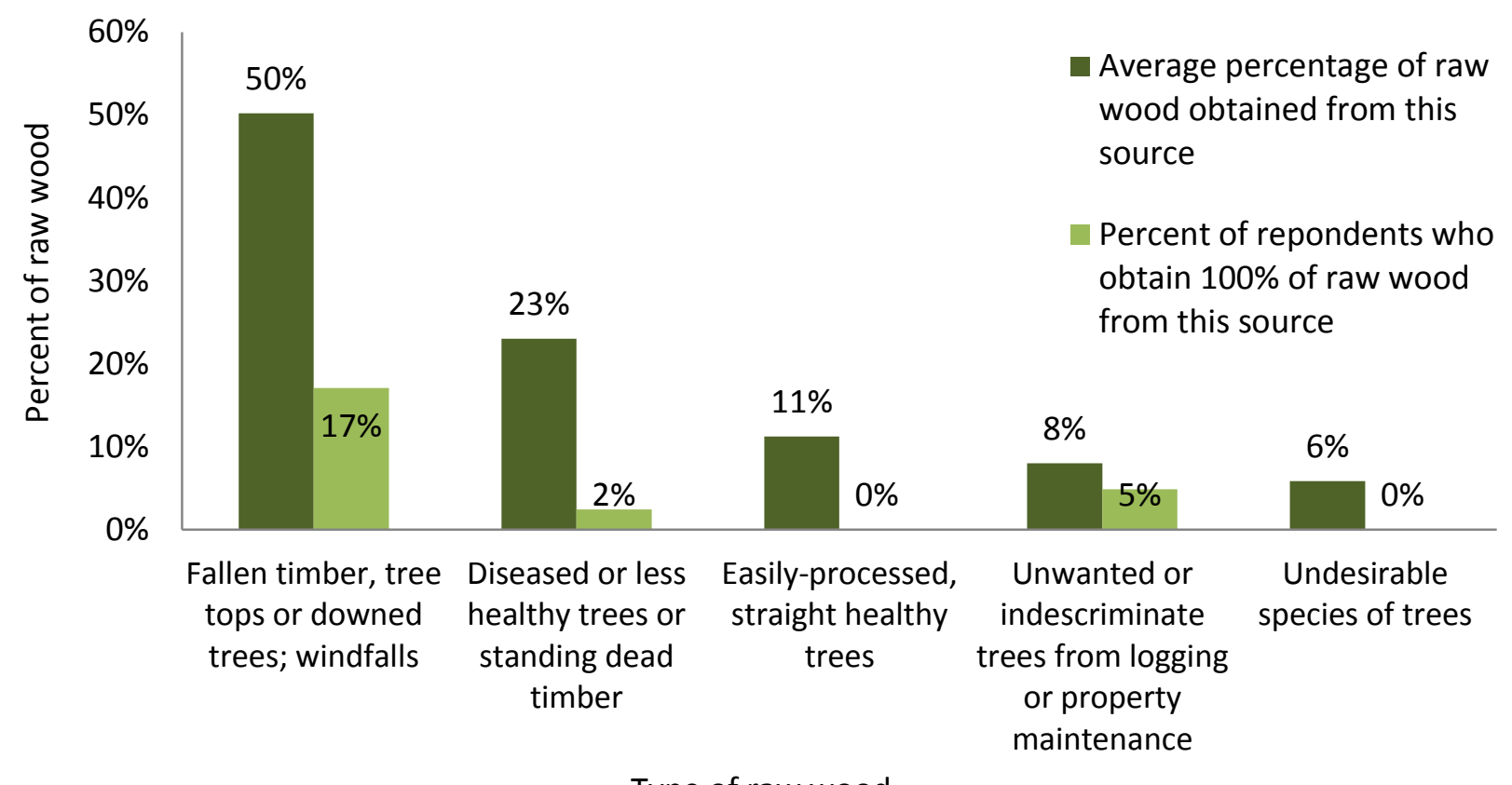

Type of raw wood

Figure 14. The types of raw wood utilized by mail questionnaire respondents.

Almost half of mail questionnaire respondents (48\%) are aware of laws and regulations in the state of West Virginia pertaining to the movement of firewood. Seventy-four percent indicated that their business is not affected. Out of the three respondents who indicated that they were unaware of any regulations, two indicated that their businesses were unaffected and one was not sure. Therefore it is uncertain whether those questionnaire respondents who answered that they were not aware of regulations and also did not list how their businesses were affected experience no issues as well $(\mathrm{n}=19)$. The most known firewood pests reported were the Emerald Ash Borer (51\%), followed by the European Gypsy Moth (27\%) and the Hemlock Wooly Adelgid (16\%).

The firewood Best Management Practices that mail questionnaire respondents found least difficult ("somewhat easy" or "very easy") were selling firewood within 50 miles of where it was harvested (12\% of 41 respondents); using standard volumes such as cubic feet or "cords" (12\% of 41 respondents); and leaving healthy trees and wildlife habitat when harvesting firewood (10\% of 40 respondents) (Figure 14$)$. Fifty percent $(n=21)$ of questionnaire respondents indicated that they were willing to earn a "Community Firewood Dealer" certificate; fifty-seven percent of the seven respondents who gave explanations thought it would be good for business and $43 \%$ were interested in gaining knowledge. Out of the 21 respondents who were not willing 
to certify and gave explanations $(n=13), 46 \%$ did not think certification was worth the hassle, and $31 \%$ indicated that they did not have the time (Table 9). Seventy-nine percent of all questionnaire respondents indicated that they did not think it likely that their customers would pay more for certified firewood.

\section{Firewood Best Management Practice}

Heat-treating firewood

Obtaining a complaince agreement from the USDA

De-barking \& seasoning firewood for $1+$ yrs

Giving customers sales receipts detail wood origin and type, and business contact

Keeping records of sales including wood origin and type, customer contact information and dates and locations of sales or deliveries

Selling firewood locally, within 50 miles

Using standard volumes, such as cubic feet or "cords"

Leaving healthy trees and wildlife habitat when harvesting firewood
Percent of Respondents Not Able to Comply

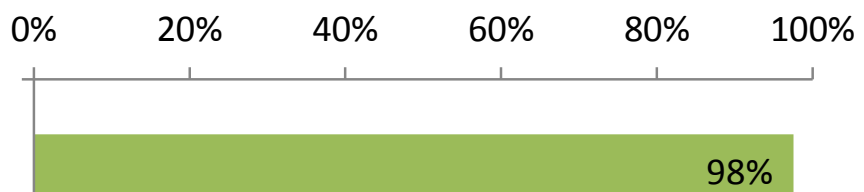

$85 \%$

\section{$37 \%$}

$32 \%$

\section{$76 \%$}

\section{$12 \%$}

$10 \%$

Figure 15. The firewood Best Management Practices with which mail questionnaire respondents would find "somewhat difficult" or "very difficult" to comply. 
Table 9. Reasons given by mail questionnaire respondents for why they would or would not choose to earn a community firewood dealer certificate.

\begin{tabular}{lc}
\hline Reasons to Certify & Percent of Responses $(\mathbf{n}=\mathbf{7})$ \\
\hline Good for business & $57 \%$ \\
Get information/knowledge & $43 \%$ \\
Networking & $14 \%$ \\
\hline Reasons Against Certifying & Percent of Responses (n =13) \\
\hline Not worth it & $46 \%$ \\
No time & $31 \%$ \\
Don't sell enough & $23 \%$ \\
Personal use only & $8 \%$ \\
Cost & $8 \%$ \\
\hline
\end{tabular}

\section{Safety Practices}

Mail questionnaire respondents reported spending the most time each week on harvesting and cutting their firewood (average $=9.84$ hours), followed by splitting (average $=8.21$ hours) (Table 10). Forty-four percent of questionnaire respondents indicated that they use no help in producing firewood; family members were reported as the most common source of help (51\%). Seventy-four percent of respondents indicated that they or their workers cut or process firewood alone at times. Only 12 of the 23 respondents (52\%) who use help specified the kinds of safety training that they provide to workers: eighty-three percent of those 12 who specified safety training indicated that they encouraged general safety such as common sense and proper lifting, $42 \%$ offer instruction on how to operate equipment safely and $33 \%$ instruct on proper felling technique (Table 11). It remains unknown whether those who use workers but did not specify any safety training (37\%) offer any training at all. 
Table 10. Average weekly hours mail questionnaire respondents spend on various business activities.

\begin{tabular}{lc}
\hline Business Activity & Average Hours \\
\hline Harvesting/cutting & 9.84 \\
Splitting & 8.21 \\
Delivering/stacking & 5.59 \\
Other & 0.25 \\
Accounting, tax prep, etc. & 0.24 \\
Marketing/advertising & 0.21 \\
\hline
\end{tabular}

Table 11. Help utilized by mail questionnaire respondents and the safety training offered.

\begin{tabular}{lc}
\hline Various Help Utilized $(\mathbf{n}=\mathbf{2 3})$ & Percent of Responses \\
\hline Family members & $91 \%$ \\
Friends & $22 \%$ \\
Employees & $17 \%$ \\
\hline Safety training offered to help $(\mathbf{n}=\mathbf{1 2})$ & \\
\hline General safety & $83 \%$ \\
Operating equipment & $42 \%$ \\
Felling & $33 \%$ \\
Personal Protective Equipment & $25 \%$ \\
\hline
\end{tabular}

Over half of mail questionnaire respondents (56\%) work in the morning, between 6 a.m. and 12 p.m.; another 15\% work in the afternoon between 12 p.m. and 6 p.m. (Figure 16). All 42 questionnaire respondents reported that they use mechanized equipment and gave more than one example: chainsaws are the most-used of such equipment (98\%), followed by mechanized splitters (74\%); fifty-nine percent indicated that they utilize a tractor or skidder and only $5 \%$ of respondents indicated that they utilize a firewood processor. Four respondents $(10 \%)$ indicated that they did not use personal protective equipment when they use a chainsaw, yet two of them checked additional boxes indicating the types of PPE they use. The great majority (90\%) of all 42 questionnaire respondents do indeed utilize some form of PPE: $76 \%$ use steel-toed boots, $74 \%$ use gloves, $60 \%$ use safety glasses and $52 \%$ use ear protection. Twenty-two respondents provided reasons for not always utilizing PPE: $41 \%$ indicated that it gets in the way and slows down their progress; thirty-six percent indicated that it was uncomfortable due to temperature; 
another $27 \%$ indicated that it was not necessary (Table 12). It is unclear whether those 19 respondents who indicated that they use some form of PPE in Question 45 but did not provide any reasons they did not always use PPE in Question 46 might be indicating that they do indeed always wear PPE when operating a chainsaw or other mechanized equipment.

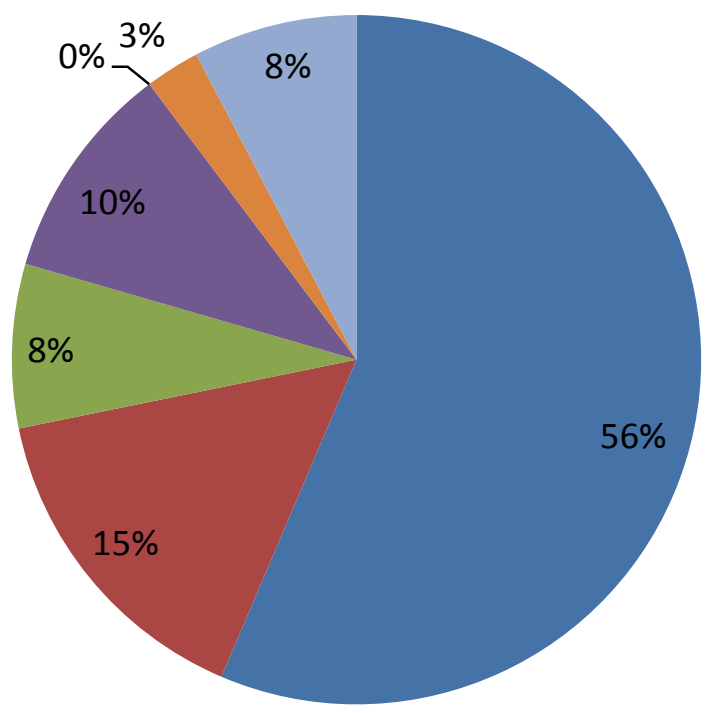

$\frac{\text { Time of day }}{\square \text { 6a-12p }}$
$\square 12 p-6 p$
$6 p-6 a$
$6 a-6 p$
$6 a-12 p$ AND 6p-6a
$\square 12 p-6 a$
ALL DAY

Figure 16. Time of day that mail questionnaire respondents produce their firewood (39 responses). 
Table 12. Types of PPE used by mail questionnaire respondents and their reasons for not always using it.

\begin{tabular}{lc}
\hline Personal Protective Equipment used & Percent of respondents \\
\hline Steel-toed boots & $76 \%$ \\
Gloves & $74 \%$ \\
Safety glasses & $60 \%$ \\
Ear muffs or plugs & $52 \%$ \\
Hardhat/helmet & $31 \%$ \\
Chainsaw chaps or pants & $24 \%$ \\
Other & $2 \%$ \\
\hline Reasons for not always using PPE & Percent of respondents (n =22) \\
\hline PPE gets in the way & $41 \%$ \\
PPE is uncomfortable because of temperature & $36 \%$ \\
PPE not necessary & $27 \%$ \\
PPE not available, or don't own any & $23 \%$ \\
PPE is uncomfortable because of poor fit & $5 \%$ \\
PPE doesn't provide adequate protection & $5 \%$ \\
No time for PPE/PPE is inconvenient & $5 \%$ \\
\hline
\end{tabular}

Almost half of mail questionnaire respondents (48\%) indicated that they had never experienced an injury. Twenty-two respondents reported most common injuries, with smashing, pinching or bruising of the hands accounting for nearly half of injuries (45\%); thirty-two percent indicated splinters or blisters of the hand to be the next most common injury (Table 13). Four questionnaire respondents $(10 \%)$ indicated that they had missed more than one day of work due to an injury from producing firewood within the last twelve months. Only two of these same respondents indicated that they had experienced injuries that required more than first aid within the same period, yet the original four elaborated on the type and circumstances of these injuries they experienced. Two of these reported injuries involved a cut or laceration of the leg while felling or processing with a chainsaw. The other two injuries reported were incurred while handling or loading firewood: one involved contracting poison ivy on the hands and face/head and one involved bruising/smashing of the head and torso from a fall off a pickup truck. 
Table 13. Most common injuries reported by mail questionnaire respondents.

\begin{tabular}{lc}
\hline Most Common Injury & Percent of Respondents (n = 22) \\
\hline Hand/Smashing, bruising or pinching & $45 \%$ \\
Hand/Splinters or blisters & $32 \%$ \\
Shoulder or Back/Sore or aching & $18 \%$ \\
Unspecified/Laceration, cut or scrape & $18 \%$ \\
Feet/Smashing, bruising or pinching & $14 \%$ \\
Unspecified/Splinters or blisters & $9 \%$ \\
Hand/Laceration, cut or scrape & $9 \%$ \\
Unspecified/Smashing, bruising or pinching & $5 \%$ \\
Unspecified/Muscular (tearing of tendons/ligaments, & $5 \%$ \\
beyond sore) & $5 \%$ \\
Unspecified/Sore or aching & $5 \%$ \\
\hline
\end{tabular}

\section{Educational Topics of Interest}

Out of the 42 mail questionnaire respondents, 24 (57\%) were interested in at least half of the eight classes listed in the questionnaire. Again the most popular class topic among respondents was pest and disease identification (76\%); the second most popular class topic was woodlot management (62\%) (Figure 17). Six respondents suggested other class topics, one each specifying a tree or wood identification class, a class on felling, a class on business management, a class on pellet production and other new products, a class about packaging and a class on sustainable forestry.

Concerning fees, $58 \%$ of questionnaire respondents indicated that they would not be willing to pay to take a class. Those who are willing to pay reported that they would pay between $\$ 10$ and $\$ 100$, with an average of $\$ 37$. Ten respondents $(25 \%)$ were unwilling to travel at all to attend a class. Those who are willing to travel reported that they would drive between five and 100 miles, with an average of 41 miles. More than a quarter (30\%) of questionnaire respondents was willing to travel over 50 miles to attend a class (Figure 18). 


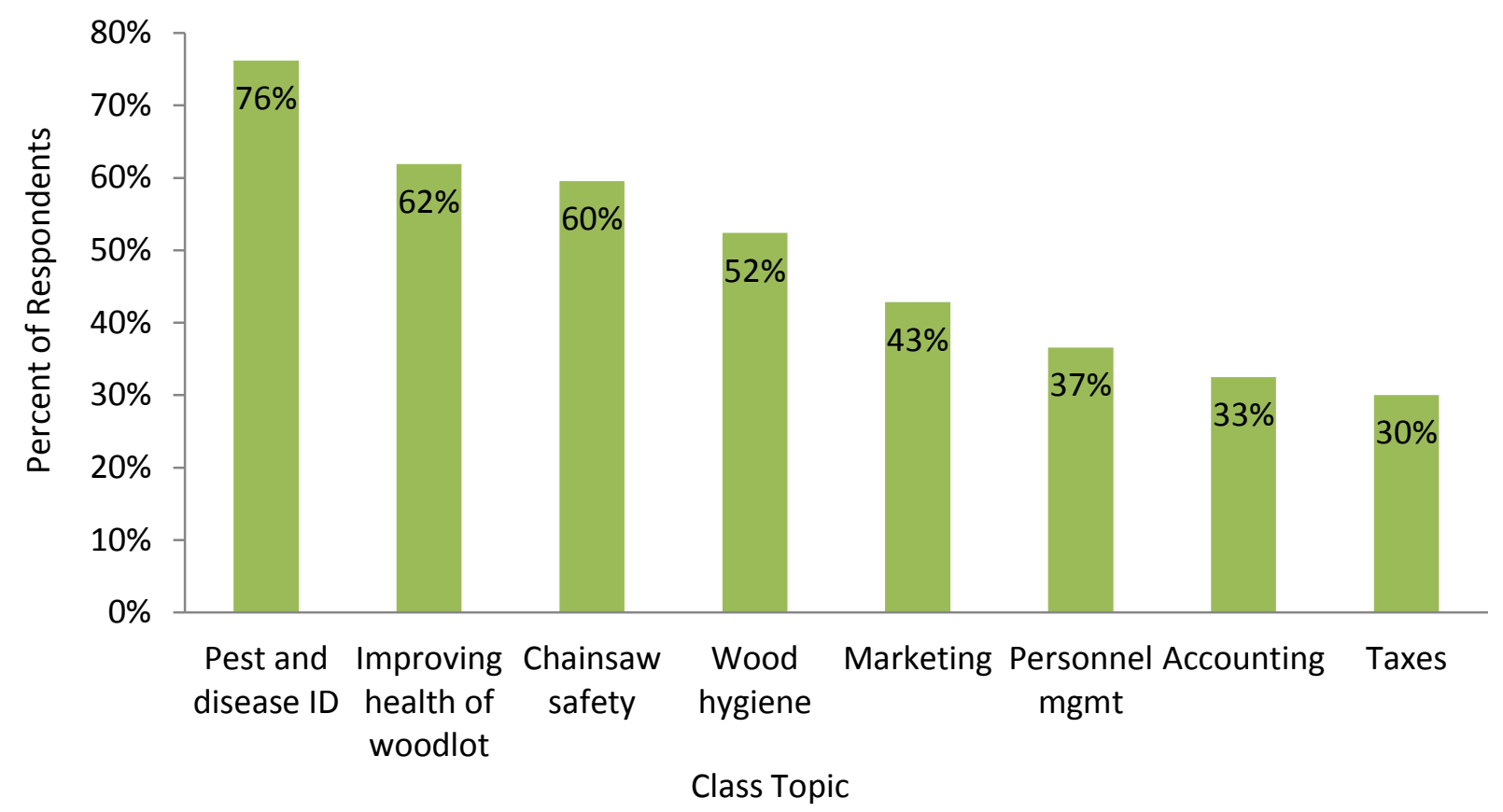

Figure 17. Percent of mail questionnaire respondents who are "somewhat likely" or "very likely" to attend various outreach classes.

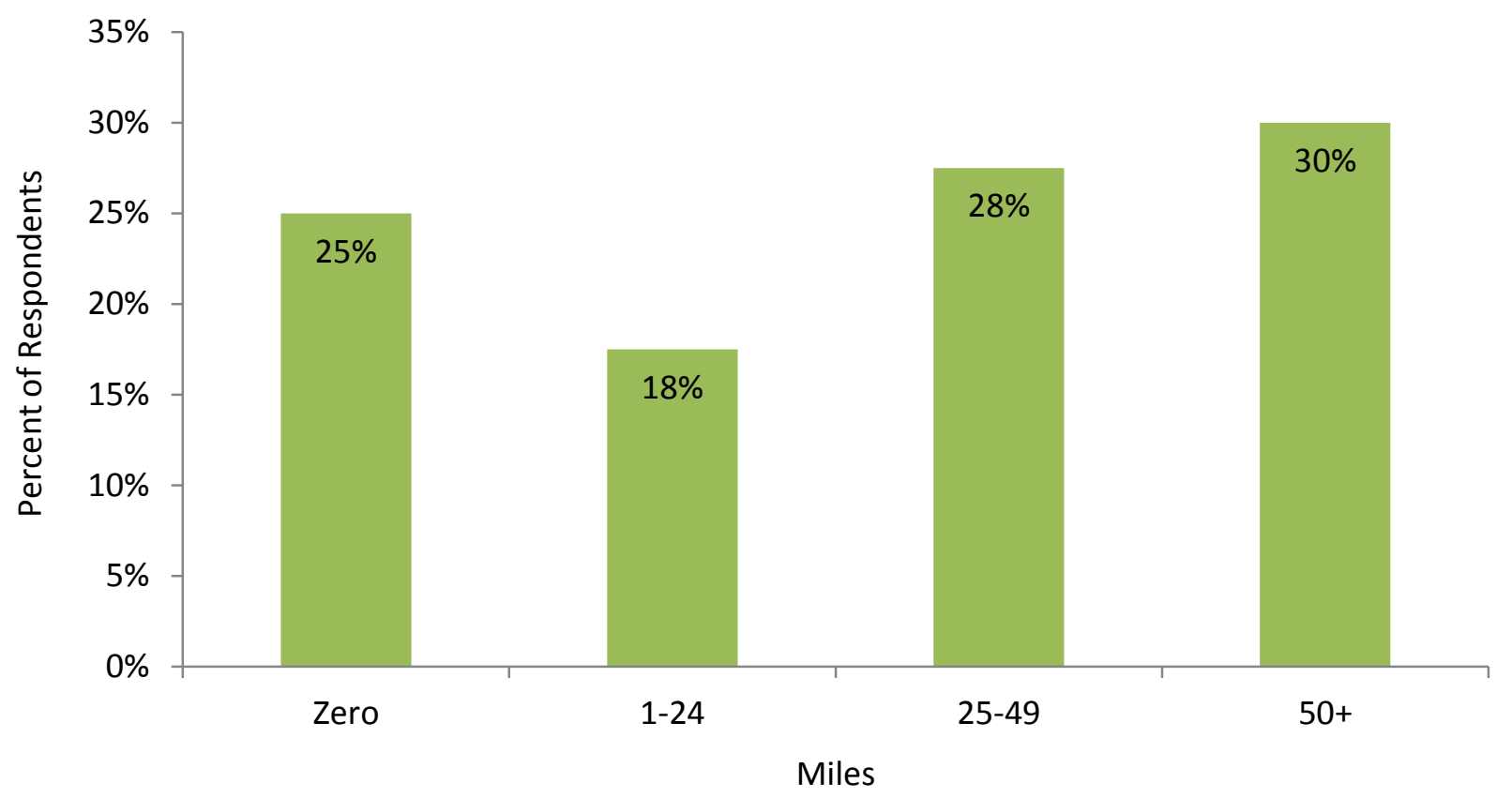

Figure 18. Maximum distance that mail questionnaire respondents are willing to travel to attend classes. 


\section{Reliability between Telephone Interview and Mail Questionnaire Responses}

\section{Comparison of corresponding answers from both surveys}

In order to test the reliability of the instruments used, corresponding results from those respondents who participated in both the telephone interview and mail questionnaire were compared. Forty-one of the 42 respondents who completed the mail questionnaire also participated in the telephone interview. Statistical tests could not be conducted on most responses concerning customer base, since no mail questionnaire respondents reported large or small retailers as part of their customer base. However, all respondents reported $100 \%$ of their primary customer base as being private individuals or homeowners for both the telephone interview and mail questionnaire (Question 1 of the telephone interview and Question 13 of the mail questionnaire), with the exception of one questionnaire respondent who did not answer the question. One and five more respondents reported large retailers and small retailers as part of their customer base during the telephone interview but not on the mail questionnaire, respectively (Table 25 Appendix B). There was no significant difference in how many respondents reported campgrounds as part of their customer base (McNemar's test $\mathrm{p}=0.564$ ).

No statistically significant differences were found in average delivery radius (Question 2 of the telephone interview and Question 17 of the mail questionnaire) $(\mathrm{t}(39)=1.372, \mathrm{p}=0.178)$, average percent income earned from selling firewood (Question 4 of the telephone interview and Question 24 of the mail questionnaire) ( $(37)=0.789, \mathrm{p}=0.435)$ or average proportion of firewood sold in West Virginia (Question 2B of the telephone interview and Question 15 of the mail questionnaire) $(\mathrm{t}(39)=-0.008, \mathrm{p}=0.994)$; in fact, 11,14 and 30 respondents did not change their answer for these questions, respectively (Table 26 Appendix B).

Concerning the types of units used by respondents (Question 3 of the telephone interview and Question 19 of the mail questionnaire), five respondents did not select pickup truck 1 as a unit on the questionnaire after indicating that they use such units during the telephone interview (McNemar's test $p=0.059$ ) (Table 27 Appendix B). Average cubic foot volumes derived from the bed dimensions that were provided for truck one and truck two were not significantly different between the two surveys $(\mathrm{t}(38)=0.221, \mathrm{p}=0.827$ and $\mathrm{t}(38)=1.182, \mathrm{p}=0.245$, respectively). Several significant differences existed regarding respondent interest in various 
class topics: nine more respondents indicated interest in the woodlot management class topic on the mail questionnaire (McNemar's test $\mathrm{p}=0.083$ ) and 14 more indicated general class interest on the mail questionnaire (McNemar's test $\mathrm{p}=0.039)$ (Table 28 Appendix B). Significantly fewer respondents $(n=19)$ reported a most common injury on the mail questionnaire (McNemar's test $\mathrm{p}=<0.0001$ ) (Table 29 Appendix B).

\section{Comparison of telephone interview-only responses to mail questionnaire responses}

For this reliability analysis, telephone interview responses from the 61 respondents who only participated in the telephone interview were compared to the mail questionnaire responses of the 41 respondents who participated in both surveys (one of these mail questionnaire respondents did not participate in the telephone interview and so those particular responses were not included in the analysis). Once again, statistical tests could not be conducted on responses concerning customer base because no mail questionnaire respondents reported large or small retailers. However, nearly all respondents reported private individuals or homeowners as their primary customer base; only one questionnaire respondent did not answer and one telephone interview-only respondent could not elaborate on his customer base because he had not sold any firewood at the time of the interview. Two and nine more telephone interview respondents reported large retailers and small retailers as part of their customer base (Table 30 Appendix B). Once again there was no significant difference in the number of respondents reporting campgrounds as their customers (Fisher's Exact Test $\mathrm{p}=0.5457$ ).

Five more telephone-only interview respondents are willing to deliver $(\mathrm{FET} \mathrm{p}=0.01)$, and are willing to travel significantly farther (mean $=35.9$ miles) to deliver firewood than mail questionnaire respondents $($ mean $=27.0$ miles $)(t(94)=1.912, p=0.059)$. The average percent income earned from firewood and the percent of firewood sold in West Virginia was not statistically different between groups $(\mathrm{t}(93)=-0.741, \mathrm{p}=0.460)$ (Table 31 Appendix $\mathrm{B})$.

Concerning units, the only significant difference that existed between the two groups was that fewer mail respondents reported using cords $($ FET p $=0.089)$ (Table 32 Appendix B). The average cubic foot volume estimated by telephone interview-only respondents for trucks 1 and 2 was not significantly different compared to mail questionnaire respondents $(\mathrm{t}(95)=1.202, \mathrm{p}=$ 0.232 and $\mathrm{t}(70)=-0.099, \mathrm{p}=0.921$, respectively). Concerning classes, there were fewer mail 
questionnaire respondents interested in the pest and disease identification class (FET $p=0.031)$, and fewer telephone interview respondents interested in the accounting class $(\mathrm{FET} \mathrm{p}=0.038)$ (Table 33 Appendix B). There was no significant difference in general class interest or number of reported injuries between the two groups; however there were several new injuries reported by mail questionnaire respondents that telephone interview respondents did not mention (Table 34 Appendix B).

\section{Analyses of Sub-groups}

We wanted to determine if certain mail questionnaire respondents might be more serious about furthering their education and improving their businesses. The responses from various questions were analyzed to statistically compare various sub-groups using Fisher's Exact Test for categorical variables and unpaired t-tests assuming unequal variances for continuous variables $(p$ $<0.1$ significant, two-tailed results only). The sub-groups were divided up according to: whether or not questionnaire respondents were willing to attain a Community Firewood Dealer certification (Question 36), whether they consider firewood production a hobby (if they circled a three or four on the Likert scale for Question 25A), whether they were between 18 and 40 years

of age or over the age of 40 (Question 56), whether or not they mentioned that they began selling firewood for supplemental income (even if multiple answers were given for Question 2), and whether or not they had a general interest in classes ("somewhat likely" or "very likely" to attend at least four class topics from Question 51) (Table 35 Appendix C).

Every single variable that was examined from the total sample was also examined for each sub-group. Due to sample size limitations, only those $\chi^{2}$ analysis results that were significant and also had less than $20 \%$ of cells with expected counts less than five are reported here, using one-sided Fisher's Exact Test statistics. There are noticeable differences in the data for many questions between these respective groups, but the idea is that if the sample were bigger, these differences might become statistically significant. Selected results from these analyses are presented in Appendix C. 


\section{Sub-group Willing to Attain Community Firewood Dealer Certification}

There were few statistically significant differences between the subgroups willing to certify and those unwilling to certify concerning various business, wood hygiene and safety practices, when compared with the number of variables tested. Those respondents willing to certify make a significantly higher average percentage of their personal individual income from selling firewood $(19.0 \%$ compared to $5.8 \%, \mathrm{t}(24)=2.088, \mathrm{p}=0.047)$. They are also statistically more willing to pay at all to attend a class (FET $\mathrm{p}=0.006)$; pay $\$ 19.58$ more on average to attend a class $(\mathrm{t}(24)=2.452, \mathrm{p}=0.021)$; more willing to travel at all to attend a class (FET $\mathrm{p}=$ $0.065)$.

However, those respondents willing to certify are not willing to travel significantly farther to deliver their product to their customers $(\mathrm{t}(33)=0.9849, \mathrm{p}=0.332)$. They also did not sell significantly more firewood volume last year $(\mathrm{t}(31)=0.077, \mathrm{p}=0.939)$ and do not expect to sell firewood for many more years than those not willing to certify $(\mathrm{t}(35)=0.524, \mathrm{p}=0.604)$ (Table 36 of Appendix C). In addition, as can be seen in Figure 19 of Appendix C, those respondents willing to certify certainly have more interest in each workshop topic, but only woodlot management proved to be statistically significant (FET $\mathrm{p}=0.024)$.

\section{Sub-group That Views Firewood Production as a Hobby}

There were even fewer significant differences between those respondents who view firewood production as a hobby and those who do not, when compared with the number of variables tested. It should be mentioned that there were only 10 respondents who did not view firewood production as a hobby, compared with 32 who did. First of all, those respondents who view firewood production as a hobby sold significantly far less volume last year ( $\mathrm{n}=15$ cords) as compared to those who do not view it as a hobby, who sold 118 cords last year, but this did not prove to be significant using a two-sample t-test assuming unequal variances $(\mathrm{p}=0.167)$; however, it proved significant using a one-way $\operatorname{ANOVA}(\mathrm{F}(1,34)=7.225, \mathrm{p}=0.011)$. Interestingly, those respondents viewing firewood production as a hobby spend more time on marketing ( 0.26 hours as compared to zero hours, $\mathrm{t}(30)=3.481, \mathrm{p}=0.002)$ and are willing to pay $\$ 13.28$ more, on average, to attend classes $(\mathrm{t}(34)=2.062, \mathrm{p}=0.046)$ (Table 37 Appendix 
C). Those producers not viewing firewood production as a hobby were significantly more likely to be interested in attending a class on accounting (FET p = 0.052) (Figure 20 Appendix C).

Although those viewing firewood production as a hobby were statistically more likely to report that selling firewood does not generate enough income to report to the I.R.S. (FET $p=$ 0.02 ), those not viewing firewood production as a hobby do not make significantly more of their personal individual income from selling firewood $(t(11)=-0.954, p=0.360)$. They also do not expect to continue selling firewood for significantly more years than those who view firewood production as a hobby $(\mathrm{t}(12)=-0.263, \mathrm{p}=0.797)$. Although not statistically significant at $\alpha=$ 0.1 , it is also interesting to note that more hobby firewood producers are using the internet to advertise their product (Figure 21 Appendix C).

\section{Sub-group Producing Firewood for Financial Reasons}

Those respondents who indicated that they produced firewood for any kind of financial reason $(\mathrm{n}=28)$ deliver farther (30.9 miles as compared to the non-financial average of 20.7 miles; $\mathrm{t}(32)=-1.754, \mathrm{p}=0.078$ ) and earn significantly more average personal individual income $(16.6 \%$ compared to non-financial average of $5.5 \% ; \mathrm{t}(35)=-1.998, \mathrm{p}=0.053)$ from selling firewood and sold a larger average volume last year (59.4 cords compared to non-financial mean of 7.9 cords; $\mathrm{t}(23)=-1.848, \mathrm{p}=0.078)$. Those producing for financial gain were also more likely to have a general interest in various classes (FET $\mathrm{p}=0.097$ ); specifically, they had more interest in personnel management (FET $p=0.084)$.

Respondents not producing for financial reasons are more likely to have a post-secondary education (FET $\mathrm{p}=0.052$ ) and proved to be more concerned about invasive species threatening the health of U.S. forests (FET $p=0.068$ ). These sub-groups did not differ significantly concerning the number of years they expect to continue selling firewood $(\mathrm{t}(20)=0.413, \mathrm{p}=$ 0.684) (Table 38 Appendix C). Those producing for financial reasons are more statistically likely to advertise their product via word of mouth (FET p $=0.039$ ), but at our sample size, although more respondents producing for financial reasons use the internet to advertise their firewood, this did not prove to be statistically significant (FET $p=0.196)$ (Figure 22 Appendix C). 


\section{Sub-group between 18 and 40 Years of Age}

These analyses were conducted in order to determine whether those mail questionnaire respondents who were interested in advancing their businesses were of a certain age group. Not surprisingly, those respondents over the age of 40 years have been in business a statistically longer amount of time $(18.6$ years compared to 5.6 years; $\mathrm{t}(24)=3.543, \mathrm{p}=0.002)$. However, they did not sell a statistically larger volume of firewood last year: in fact, they sold a mean of 17 cords while those respondents under the age of 40 sold a mean of 62 cords; this did not prove to be a statistically significant difference at $\alpha=0.1(\mathrm{t}(19)=1.344, \mathrm{p}=0.195)$ (Table 39 Appendix C). Those respondents under the age of 40 years were more likely to use the internet to advertise their product (FET $\mathrm{p}=0.054)$.

\section{Sub-group Likely to Attend Four or More Classes}

Those respondents who were likely to attend at least half of the classes listed in the questionnaire are more likely to travel further to harvest raw wood (20.3 miles compared to 10.9 miles; $\mathrm{t}(40)=1.840, \mathrm{p}=0.073)$ and attend classes $(38.7$ miles compared to 19.9 miles; $\mathrm{t}(25)=$ -

$0.295, p=0.039$ ). They also earn more of their average personal individual income from selling firewood $(18.9 \%$ compared to $3.4 \%$; $\mathrm{t}(28)=2.788, \mathrm{p}=0.009)$, are more willing to certify (FET $\mathrm{p}=0.028)$ and are more willing to pay to attend classes (FET $\mathrm{p}=0.096)$.

However, these respondents did not sell more firewood volume last year $(\mathrm{t}(25)=-0.084$, $\mathrm{p}=0.934)$; they are also not willing to travel farther to deliver firewood to their customers $(\mathrm{t}(40)$ $=0.917, \mathrm{p}=0.364)$. They also do not plan on selling firewood any longer than those without a general interest in classes $(\mathrm{t}(27)=-0.455, \mathrm{p}=0.652)$ and are unwilling to pay a significantly greater amount to attend classes $(\mathrm{t}(34)=1.263, \mathrm{p}=0.215)$ (Table 40 Appendix $\mathrm{C})$. 


\section{CHAPTER V: Discussion}

\section{How West Virginia Firewood Producers Compare to Other Producers}

The results from this two-part survey are consistent with past studies of firewood producers both in the United States and abroad. For instance, West Virginia firewood producers may enter and leave the industry repeatedly, depending on raw wood supply and available time for processing. Some respondents were not able to answer some questions (such as percent income from selling firewood or volume sold last year) due to the fact that they had just begun producing firewood. Nearly half of surveyed West Virginia producers $(n=19)$ identified supplemental income as at least one reason for why they began selling firewood; all producers surveyed in North Carolina in 1984 identified their firewood operations as part-time, run solely for extra income (Marsinko 1984).

The majority of our respondents self-identified as individual producers, but $15 \%$ selfidentified as loggers that sell bucked logs or firewood and another 7\% identified themselves as a tree care company that sells waste wood for firewood; this involvement of logging and tree care companies is typical of firewood markets in other U.S. states and Scotland (Andrews \& Dammann 1978, MacIntyre 2007, Seeland 2007). West Virginia producers have been selling firewood for an average of 11.9 years; firewood producers surveyed in New Hampshire in 1987 had been in business for an average of nine years (Evans \& Parker 1987). However, respondents in this project were not asked to specify the time of year that they typically produce firewood. This is normally a seasonal activity for producers surveyed in Australia (MacIntyre 2007); in Scotland and Finland, producers cut firewood in the winter since they are busy farming during the summer (MacIntyre 2007, Raitila 2008). Gorman and Elder (2009) also characterized smaller firewood operations in Alaska as typically being seasonal.

Unlike Pennsylvania producers surveyed in 2007, 40\% of whom were "somewhat concerned" or "highly concerned" about invasive firewood pests threatening U.S. forests, the majority of surveyed West Virginia firewood producers generally agree that these invasive pests are a threat $(79 \%)$ and that the success of their businesses is directly related to healthy forests (83\%) (Ellis et al. 2008). They are concerned that their businesses may be affected by the health 
of West Virginia forests in the near future (67\%) and believe that the West Virginia firewood industry can help maintain forest health (97\%). This difference in concern could reflect the success of state and federal outreach programs since 2007, based on studies of public outreach concerning invasive species (Fairbank, Maslin, Maullin \& Associates 2006, Runberg 2011).

Firewood producers in West Virginia travel an average 16 miles to harvest raw wood to be processed into firewood; this could reflect the fact that most of the state is rural and forested. Skog and Watterson's (1984) nationwide telephone survey of firewood consumers conducted during the 1980-81 heating season found that the average distance rural residents had to travel to harvest their firewood is 13 miles, while urban consumers travel an average 33 miles and the national average was 22 miles. A quarter of surveyed producers in Scotland reported traveling 10 miles or less to collect their firewood (MacIntyre 2000); Australian producers reported traveling between 77 and 132 miles to harvest their raw wood, and over half travel less than 124 miles (Driscoll et al. 2000). This difference could perhaps be attributed to the proximity of forested land in West Virginia, since it is the third most forested state in the U.S. (Widmann 2012).

West Virginia producers collect fallen timber, tree tops or downed trees from windfalls (50\%) for their firewood, while "limited evidence suggests commercial harvesters [in Australia] may target standing dead trees," (Driscoll et al. 2000, page 24). Scottish producers collect raw wood in their own woodlots, as well as procuring some from tree surgery operations, sawmill and Forestry Commission management activity waste and timber merchants; some buy it ready split (MacIntyre 2007). Illinois producers surveyed in 1980-81 collected 34\% of their raw wood as dead and down woodlot timber, another 21\% from logging residue and another $19 \%$ from land clearing activities (Giacoletto 1982). Pennsylvania producers reported acquiring the majority (56\%) of their wood from tree service companies, followed by land clearing companies (24\%) and lumber mills (24\%) (Ellis et al. 2008). This difference in raw wood sources could be due to small sample bias in our project or the fact that our survey asked respondents whether they purchased raw wood from these sources - respondents may not have indicated that they acquired raw wood from these sources due to this wording; eighty-seven percent acquire free wood, however. 
The primary customer base of West Virginia firewood producers is private individuals or homeowners (100\%) who live in West Virginia (93\%); this domestic customer base is typical among smaller producers in other studies (MacIntyre 2007, Ellis et al. 2008). West Virginia firewood producers who responded to the mail questionnaire did not report small or large retailers (such as grocery store chains) as being at all part of their customer base, but $14 \%$ ( $\mathrm{n}=$ 14) of the telephone interview respondents reported smaller retailers as customers. Pennsylvania producers reported $4 \%$ of their sales as small retailers and $4 \%$ to grocery store chains; they also reported most or all of their customers (96\%) being within the state (Ellis et al. 2008).

West Virginia producers are willing to travel an average 29.6 miles to deliver firewood to their customers, which is almost the exact same average delivery radius of Scottish producers (30 miles) (MacIntyre 2007). Smaller New Hampshire producers surveyed in 1987 reported traveling an average of 13 miles and medium-sized producers 25 miles to deliver (Evans \& Parker 1987). Respondents in this study sold approximately 45.9 cords last year and earn on average $12.7 \%$ of their personal individual income from selling firewood. Therefore they are smaller producers (selling less than 50 cords annually) like those characterized by Andrews and Dammann (1978) in New Hampshire in 1977, which are typically operating in the informal market in the U.S. and abroad (Marsinko 1984, Driscoll et al. 2000, MacIntyre 2007, Nybakk 2012). They advertise their product primarily by word of mouth (66\%), which is consistent with studies of Finnish producers (Raitila 2008) and Scottish producers (MacIntyre 2007). Illinois producers surveyed in 1980-81 relied mostly on newspaper ads (63\%), but another quarter depended on a combination of newspaper ads and word of mouth (25\%), or just word of mouth (22\%) to market their product (Giacoletto 1982).

Ninety-eight percent of surveyed West Virginia firewood producers season their firewood for an average of 8.4 months, but they do not sanitize their firewood in any other way. Although this may be an acceptable amount of time to produce an adequately seasoned product, if there were borer beetle larvae within it, they could easily be transported to new areas. As stated before, West Virginia firewood producers that responded indicated an average delivery radius of 29.6 miles, which is well below the 50-mile limit suggested by the U.S.D.A. However, nine respondents (21\%) indicated that they are traveling more than 50 miles to deliver firewood at 
times; one respondent indicated that he travels over 100 miles sometimes. This has serious implications for the spread of invasive pests.

Seventy-five percent of respondents from our survey indicated that they sell by the pickup load/truckload, the average bed of which they estimate holds almost a cord (126.9 cubic feet), for an average price of $\$ 92.50$. It is likely that these respondents overestimated the size of their truck beds as measures of firewood volume, according to Marsinko (1984). They may or may not also sell by the cord (30\%) for an average price of $\$ 157.27$ or the half cord (28\%) for an average price of $\$ 80.68$. Firewood bought from the unregulated commercial firewood market of smaller producers in Australia is worth approximately $\$ 120 /$ tonne, or $\$ 120 /$ half cord $(0.55$ cords after using the article's conversion of two cubic meters per tonne) (Driscoll et al. 2000), while a cord of cut and split firewood in N.H. in 1987 was found to be worth an average $\$ 85.18$ (approximately $\$ 175.37$ after correcting for inflation) (Evans \& Parker 1987, U.S. Department of Labor Bureau of Labor Statistics 2013). Illinois producers surveyed in 1980-81 sold delivered firewood for an average of $\$ 65.00$ per cord (approximately $\$ 157.72$ per cord after correcting for inflation) (Giacoletto 1982, USDL BLS 2013).

West Virginia firewood producers may be aware (48\%) of laws or regulations in the state that limit the movement of firewood, most likely because their businesses are generally unaffected (74\%). The firewood pest that West Virginia firewood producers have heard of mostly is the emerald ash borer. They are most likely to employ the following firewood best management practices: selling firewood locally (within 50 miles of its origin) (88\%), using standard volumes (such as the cord) (88\%), and leaving healthy trees and wildlife habitat when harvesting firewood (88\%). Pennsylvania producers were almost resoundingly against heat treatment of firewood (76\%); West Virginia producers are also more likely to find this BMP "somewhat difficult" or "very difficult" to comply with (98\%). Pennsylvania producers were also not likely to de-bark (64\%) or store their firewood for more than two years (44\%); seventysix percent of surveyed West Virginia producers found de-barking and seasoning their firewood for one year or more to be difficult. Producers surveyed in Minnesota on various proposed firewood regulations found labeling to be the most acceptable; an overwhelming majority was against kiln-drying or otherwise treating firewood originating within the state, but supported seasoning requirements for firewood originating from outside the state (Seeland 2007). 
Fifty percent of surveyed West Virginia firewood producers are willing to become a certified Community Firewood Dealer by attending various classes and adhering to BMPs. The other half may not view this certification as worth it (29\%) because they think their customers would be "somewhat unlikely" or "highly unlikely" to pay more for certified "pest-free" firewood (79\%), which is consistent with Pennsylvania producers, $40 \%$ of whom also did not think their customers would pay more; another $24 \%$ thought that at least $10-30 \%$ of their customers would pay more (Ellis et al. 2008). Minnesota producers were also resoundingly against state licensing which would require them to comply with the Worker's Compensation Insurance Law and be part of a centralized organization that would keep them updated on invasive pests that can be transported in firewood (Seeland 2007).

West Virginia firewood producers typically spend the most weekly time (9.8 hours) harvesting or cutting raw wood, followed by splitting ( 8.2 hours), then delivering (5.6 hours). In a study of family forest owners in Sweden engaging in fuelwood processing, it was found that these families spend the most average annual hours stacking $(n=89.9)$, splitting $(n=85.4)$, cutting $(n=78.5)$ and transporting $(n=66.9)$ firewood. It was also found that men spent $58.8 \%$ of their time processing firewood, while women spent $60 \%$ of their time handling and transporting it (Lindroos et al. 2008). West Virginia firewood producers typically work alone (74\%); 21 of the 23 respondents who use help typically turn to family (91\%). This finding is consistent with the social circles of smaller Norwegian firewood producers (Nybakk et al. 2012), and the previously mentioned studies of small-scale family forest owners in Sweden (Lindroos 2007, Lindroos et al. 2008).

The majority of West Virginia firewood producers work between 6 a.m. and 12 p.m. $(56 \%)$ and nearly half (40\%) indicated never having experienced an injury, while occasional woodcutters in Wisconsin reported being injured typically in the afternoon or evening (12 p.m. to midnight) (Fischer et al. 2005). All West Virginia firewood producers who participated in this mail questionnaire reported using some kind of mechanized equipment, the most likely pieces being chainsaws (98\%), splitters (74\%) and tractors (52\%). This is typical mechanical equipment utilized by small- and medium-sized firewood operations in New Hampshire (Evans $\&$ Parker 1987). Injuries from mechanical equipment were among the top five reported by occasional woodcutters in Wisconsin (Fischer et al. 2005). Injuries from chainsaws, firewood 
splitters and tractors caused most reported injuries experienced by self-employed private forest owners in Sweden in a study conducted by Lindroos and Burström (2010).

Lack of PPE (overall third ranked response when open-ended) and faulty, improper or inadequate PPE (overall fifth ranked when respondents given a list) were among the top five reasons for injuries incurred by occasional woodcutters in Wisconsin (Fischer et al. 2005). Ninety percent of West Virginia firewood producers wear some form of PPE when operating a chainsaw, albeit minimal: steel-toed boots (76\%), gloves (74\%), safety glasses $(60 \%)$ and ear protection (52\%). Swedish self-employed forestry workers surveyed in 2001 frequently used ear, eye and foot protection, but were less likely to wear protective pants and gloves (Neely \& Wilhelmson 2006). Midwestern farmers surveyed in 1995-96 reported wearing goggles, heavy gloves and steel-toed boots most frequently, if ever (Carpenter et al. 2002). Half $(\mathrm{n}=22)$ of West Virginia producers who responded may not wear PPE all the time; thirty-six percent of these think the gear can be uncomfortable because of temperature; another $27 \%$ did not think it was necessary because the work was not dangerous. These findings are consistent with studies of Midwestern farmers (Carpenter et al. 2002) and the previously mentioned occasional woodcutters in Wisconsin (Fischer et al. 2005). Almost half (49\%) of the 42 West Virginia firewood producers who responded did not indicate any reasons for not always wearing PPE; as mentioned in the results section, it is uncertain whether they are implicitly stating that they do indeed always wear some form of PPE when operating mechanical equipment.

Younger (13-49 years of age) occasional woodcutters in Wisconsin had a higher occurrence of mechanical injuries (59\%) while those woodcutters over the age of 50 had a higher likelihood of being struck by an object (78\%). The researchers speculated that this could reflect experience with age and use of equipment, but also slower reaction times (Fischer et al. 2005); falls and woodcutting injuries are also common injuries experience by older farmers (Browning et al. 1998). Three of the four West Virginia producers who provided details in the questionnaire on injuries that they had experienced in the last 12 months requiring more than first aid were between the ages of 18 and $30(n=2)$ or 30 and $40(n=1)$; the former group encompassed the two respondents who experienced chainsaw lacerations of the legs mentioned in results. The producer that fell from his pickup truck while loading firewood was over the age of 50. Male forest owners in northern Sweden between the ages of 40 and 59 or 50 and 69 were the most 
likely to be injured while engaging in forestry work such as woodcutting (Lindroos et al. 2008, Lindroos \& Burström 2010). This might also be because the average firewood producer in northern Sweden is between the ages of 40 and 60 and puts in the most man-hours processing fuelwood (Lindroos et al. 2008).

\section{West Virginia Firewood Producers Who May be willing to Engage in Outreach}

Based on analyses of responses from the aforementioned sub-groups of mail questionnaire respondents, West Virginia producers over the age of 40 years have been selling firewood for a significantly longer time than younger producers. Those producers who are willing to certify earn more of their average personal individual income from selling firewood; significantly more of these respondents are producing firewood for financial reasons and have a general interest in classes. They are also more likely to use the internet- especially if they are under the age of 40 - to advertise their product and are willing to pay more and travel farther to attend a class.

If respondents are producing for financial reasons, they tend to travel significantly farther to deliver and produce significantly more yearly volume; these respondents are also more likely to be interested in at least half of the class topics listed in the questionnaire. Those who view firewood production as a hobby sell significantly far less volume and spend significantly less weekly time on marketing. They are also generally unwilling to spend money on classes,

probably because they have little interest in expanding their businesses. These respondents not producing for financial reasons are statistically more likely to have a post-secondary education, but do not necessarily earn significantly more income than those respondents producing for financial reasons.

\section{Data Limitations}

\section{Sample Frame}

The database of producers developed for this project may not be an accurate cross-section for the state of West Virginia due to the fact that the enumeration of the firewood producer 
population never has been, and may never be, completed, so estimating the total population is problematic. Two limitations exist: the part of the population that is not included in the sample and the part of the sample that does not reply. Except for in uniform populations, the larger the sample is, the greater the probability that it would provide a more accurate representation of the overall population.

Clearly, with more time and continued effort tracking down producers using the various methods conducted here, we would gain a better understanding of West Virginia's firewood industry. The firewood industry is known for having an informal, opportunistic "grey" market in several countries (MacIntyre 2007, Raitila 2008), so even though telephone numbers were collected for almost a year, it was evident that there were more unique producers advertising after the cut-off date for this project. Based on personal experience during this project and the difficulties past researchers have had with producer surveys, it is known that there are smaller producers in the state who advertise solely by word of mouth and/or sell firewood from the back of pickup trucks on the side of the road that could not be contacted by telephone to participate (Andrews \& Dammann 1978); many of these were likely not represented in our survey.

Many telephone numbers $(\mathrm{n}=50)$ became disconnected during the course of this project. It is reasonable to assume that if we had called telephone numbers as we collected them, instead of accumulating them for months before beginning calls, we would have reached more respondents. Had we had a consistent protocol concerning calling non-contacts $(\mathrm{n}=113)$ a second time or perhaps even though a third time, we might have also reached more respondents. However, based on previous research on firewood producer practices, it is not likely that many anomalous cases would have been found, or that these non-respondents would have differed significantly (Evans \& Parker 1987).

\section{Instrument Reliability}

These instruments both exhibited fewer than seven statistically significant differences between answers from the 27 "questions" considered. There were only four statistically significant differences in corresponding responses from the respondents who participated in both surveys, and only five statistically significant differences between the answers of telephone interview-only respondents and mail questionnaire respondents (15\% and 19\%, respectively). 
The telephone interview-only answers may differ more from mail questionnaire answers because there were 61 telephone interview-only respondents as compared to only 41 mail questionnaire respondents. It should be noted that although these instruments may have proven reliable in this particular study, researchers desiring to use our results should keep in mind the aforementioned uncertainty in variability of the firewood producer population in the state.

\section{Telephone Interview}

We did not have a specific protocol to distinguish eligibility while conducting telephone interviews for this project. Certain former producers refused to participate, either because they did not think they were eligible since they no longer sold firewood, or they simply did not feel like participating. Some former producers were happy to participate. Still other respondents participated in the survey but partly through the interview admitted to being "one-timers." However, the purpose of this survey was to be exploratory, so therefore due to the uncertainty and dynamic nature of the population, these telephone interview results should be viewed as a "snapshot" of the industry.

As previously mentioned, a great majority of respondents sell by the truckload and most likely overestimated the size of their truck beds as measures of firewood volume, according to Marsinko (1984). It may also be safe to assume that some respondents may have underestimated the distance they drive to harvest and/or deliver firewood, or how much income they earn from selling firewood, due to wariness of any sort of regulatory organization learning of such practices.

\section{Mail Questionnaire}

Originally 80 of the $102(78 \%)$ telephone interview respondents agreed to participate in the mail questionnaire part of the survey; only 42 (52.5\%) gave satisfactorily complete, eligible responses. When compared to the original 287 eligible contacts, this response rate is only $15 \%$. Any questionnaires with at least 40 questions answered, (approximately $60 \%$ of the questionnaire) was considered complete. Many respondents misinterpreted the language of certain questions and may have answered questions not applicable to them or skipped others. 
Non-response bias could not accurately be measured since the survey was conducted on a rolling basis and there was no way to know why certain telephone interview respondents who originally gave their address so they could participate never returned their questionnaires. However, in a survey of firewood producers in New Hampshire conducted by Evans and Parker with a response rate of $70 \%$, non-respondents contacted by phone did not prove to be significantly different from respondents in size or type of business (Evans \& Parker 1987).

Again, some respondents may have underreported the income they earn from selling firewood, how far they drive to harvest or deliver their firewood, and most likely overestimated both the volume of firewood they sold last year and that which their pickup trucks can hold; their estimates may have changed had they been required to give volumes in cords. Respondents may have also rated the difficulty of various firewood best management practices based on opinion or desire to comply, rather than based on whether or not they were capable of complying.

It would be difficult to determine which respondents who did not specify any safety training provided to workers $(n=11)$ simply skipped Question 40 because they do not provide training or because they did not want to elaborate; or they may not be personally educated on safety practices. It would also be difficult to ascertain what percentage of respondents who did not report any injuries (Questions 47-50) were non-responses as opposed to never having experienced an injury. Follow-up questions may have prevented these uncertainties, but also would have lengthened the survey further. Suggestions on improvements to the mail questionnaire are provided in the next section entitled Recommendations and Future Work. 


\section{CHAPTER VI: Conclusions, Recommendations and Future Work}

\section{Summary of Findings}

Although this was an exploratory project with a small sample, this two-part survey yielded valuable information on the practices of West Virginia firewood producers and achieved both the objective of creating a database of producers and that of drawing a picture of the industry in the state, to the best of our ability. Many producers in the state are "small volume operators" not selling more than 50 cords per year, typically by the pickup load, which yields a negligible amount of their personal individual income; the great majority views firewood production as a hobby. They may enter or leave the industry many times, depending on the supply of raw wood and the time they have to process it, and do not invest much effort in anything besides production. Most entered the industry because they had a supply of wood either from property management activities, a main business related to forestry, or just an excess of personal-use firewood, since most acquire the majority of their raw wood from their own property for free. The majority works alone or utilizes family members for help, wears basic PPE when operating mechanical equipment and has had only minor accidents. Only half have heard of firewood regulations, and are not typically affected by them since they do not drive long distances to deliver; the majority seasons their firewood less than one year. A rudimentary visual diagram of the West Virginia firewood supply chain created by the author based on the results from this project can be seen in Figure 26 of Appendix H.

Many West Virginia producers plan to continue producing and selling firewood into the future but did not express much interest in developing their businesses beyond their local market. However, those willing to certify or producing firewood for any financial reason are more likely to have more developed businesses (larger volumes, more income) and are thus also more likely to be interested in classes, including paying for and traveling to attend them. They are most interested in pest and disease identification and woodlot management workshops because they procure most of their wood from their own forest land, and these classes may help them with other forest management objectives. Most producers are willing to comply with the best management practices of leaving healthy trees and wildlife habitat when harvesting firewood, 
not transporting firewood farther than 50 miles from its origin and providing customers with standard acceptable firewood volumes such as the cord.

\section{Suggestions for Improving Two-part Survey Design and Future Work}

\section{Sampling Frame}

In the future, it may be prudent to restrict the sampling frame to only in-state producers, since it was difficult for out-of-state or tri-state producers to determine how much of their firewood was sold to West Virginia consumers, if any. A separate survey should also be conducted for vendors selling firewood as a sideline to a main business such as tree care or logging; several were included in this survey only to see if and how these businesses contribute to the firewood industry in West Virginia, in an effort to paint a picture of the entire industry.

\section{Telephone Interview}

This two-part survey proved successful at engaging a historically difficult population to study, using a "foot-in-the-door" approach of coaxing respondents both to first give basic information over the telephone and establish some semblance of a working relationship, and then to participate in a more in-depth mail questionnaire (Reingen \& Kernan 1977). However, there are certain issues that need to be addressed should another researcher desire to replicate this project. First of all, as mentioned in the Limitations section, calls should be conducted as telephone numbers are collected, because there is only a small window of opportunity to contact some of these individuals, since they seem to cycle through cell phone plans and the firewood industry often. This would also lend a sense of chronology to results, highlighting the dynamism of the industry and the fact that some individuals may sell firewood one time or many times.

Also, a set of specific respondent eligibility criteria should be established before calls begin, to distinguish tree care companies, landscaping companies and loggers selling firewood as a sideline to their main businesses from individuals selling firewood and to avoid including responses from one-timers that could skew results. A call-back protocol should also be established so that more non-respondents are reached: a second call attempt should be made within one to two weeks after the first call so that the project remains fresh in the potential respondent's memory from previous voicemail messages. 
Concerning the questions asked during the interview, the only change that may need to occur is the wording of Question 2B: instead of being asked about the proportion of firewood sold in West Virginia, respondents should be asked about the proportion of their customers in West Virginia, so that responses from both surveys can be properly compared. Also, it may help to acquire more accurate results if respondents are asked for a maximum delivery radius for Question 2A, since the language may have made them believe that we were asking for the maximum round-trip distance they were willing to deliver.

It would also be interesting to practice a sort of subliminal outreach if this project were replicated, by asking telephone interview respondents if they have heard of any firewood regulations or pests. These responses could be compared with their mail questionnaire responses concerning the same topics, and perhaps highlight any investigation that they performed on their own in the interim period.

\section{Mail Questionnaire}

There are quite a few changes that could be made to the mail questionnaire to produce more reliable results in future surveys. First of all, respondents should be asked if this is their first year in business; the desired response space for Question 1 should also have both years and months. Secondly, any questions concerning distance driven to harvest, deliver and attend classes should specify that the radius is desired, not the round-trip mileage. Perhaps respondents could list how many counties they procure their raw wood from as well, and the respective percentages from each county. Question 9 concerning sources of raw wood should separate that which is acquired at no cost and that which is purchased. There should also be a follow-up question asking respondents to list the tree species they typically harvest to sell as firewood, as well as respective percentages of each.

Question 18 regarding delivery charges should be split into two questions: one asking whether respondents charge at all and another offering several pre-set responses as well as an open-ended response option. Question 19 concerning units used should have not only options for pickup trucks used, but also options for larger dump trucks and trailers and their respective dimensions; "face cord" should also be defined. Question 20 concerning the volume sold last 
year should request amounts and specific units of the respondent's choice, and allow for multiple responses.

Question 28 concerning how many months respondents season their firewood should ask for a range, since many respondents gave one. Questions should be added regarding how or where respondents heard about various regulations and forest pests and diseases, in order to pinpoint the state and federal outreach methods that are successful at informing the most people in this population. Another follow-up question should be added to Question 37 asking respondents why they do or do not think their customers would pay more for certified "pest-free" firewood, in order to determine whether there is a gap in perception between producers and consumers concerning this marketing aspect.

In Question 38, "delivering/stacking" could be split up, because a study of family forest owners in Sweden engaging in fuelwood processing found that these families spend the most average annual hours stacking (Lindroos et al. 2008). This change might give an idea of how many West Virginia firewood producers actually stack their firewood as opposed to just piling it. Question 40 asks respondents what kind of safety training they offer to workers. It should first ask whether they provide any training at all, then request reasons why or why not, and finally ask for specific training details in a follow-up question. This would remove the confusion of whether a respondent who did not answer actually does not supply said training or just did not want to answer. Respondents should also be asked whether they have ever attended any kind of official safety training workshop or received any kind of safety training whatsoever themselves.

Question 42 concerning the time of day respondents typically produce firewood could provide bracketed times as answer options, such as the ones created for coding purposes in this project (Table 22 of Appendix A), as well as the options "all day" and "no specified time/whenever have time." A follow-up question should also ask respondents the typical time of year that they produce firewood, with the seasons as response options, allowing respondents to choose as many as they want. This will give an idea of the best time of year to host outreach workshops.

Questions 45 and 46 concerning PPE usage should have consistent language: "when using a chainsaw or other mechanized equipment." There should also be a follow-up question 
asking respondents whether they use the PPE they checked off in Question 45 all the time. Question 50B should ask respondents to describe the type of injury they experienced rather than how the injury occurred, because 50C already essentially asks the same question, and respondents answered similarly. There should also be a set of questions related to near-accidents or near-misses experienced by respondents within the last year and the circumstances leading up to such incidents. Very few respondents reported injuries from firewood production in this project, but they may have had more of these near-accidents. Several follow-up questions could explore how respondents' safety behavior changed after such incidents.

Due to an oversight, age groups in Question 56 were not listed properly (18-30 years, 3040 years, etc.), so some respondents may have placed themselves within the incorrect group; the ages should be listed as 18-29 years, 30-39 years, etcetera. Lastly, Question 61 which asks respondents if they are interested in joining the West Virginia Friends of Firewood Network should have a follow-up question asking them to elaborate why they would or would not join.

\section{Ideas for Future Work}

As stated in the previous section, separate statewide surveys of tree care and logging companies could be conducted to further investigate the contribution these players make to the firewood industry in West Virginia. The U.S. spent $\$ 66$ million importing firewood from 24 countries between 1996 and 2005 (Haack 2008, Weimer 2008), so there is much room for growth in the industry. A follow-up survey could also be conducted to investigate the future plans of the respondents from this project and the limitations or obstacles they view most preventing them from developing their businesses.

Only half of our respondents have heard of regulations restricting the movement of firewood in the state. It is obvious that invasive species and their effects on forest health need to be specifically addressed in outreach initiatives resulting from this project, because fewer respondents think their businesses could be affected by the health of West Virginia forests in the near future. Further research needs to be conducted pertaining to whether producers are simply uneducated on these topics or they do not care. Workshop topics that would most appeal to West Virginia firewood producers are those pertaining to pest and disease identification and improving woodlot health; these are excellent opportunities to draw a more direct line of influence between 
firewood movement, forest health and business success in order to drive home the message of the impact of these invasive species. 


\section{Literature Cited}

Adams, Sean Patrick. 2008. Warming the poor and growing consumers: fuel philanthropy in the early republic's urban north. The Journal of American History. 95(1): 69-94.

Alliance for Green Heat. October 10, 2011. Facts and Analysis on 2010 Census Heating Fuel Data. In: Heated Up! Blog. http://forgreenheat.blogspot.com/2011/10/facts-andanalysis-on-2010-census.html. Accessed October 9, 2013.

Alliance for Green Heat. 2013. 2012 Census Shows Wood Heating Continues Growth Streak. In: Heated Up! Blog. http:/forgreenheat.blogspot.com/2013/09/2012-census-showswood-heating.html?utm_source=October\%2713+Newsletter\&utm_campaign=October+ Newsletter\&utm_medium=email. Accessed October 9, 2013.

The American Association for Public Opinion Research. 2008. Standard Definitions: Final Dispositions of Case Codes and Outcome Rates for Surveys. Fifth edition. Lenexa, Kansas: AAPOR.

Baker, Andrew J. 1982. Wood Fuel Properties and Fuel Products from Woods. USDA, Forest Service, Forest Products Laboratory, Madison, Wisconsin. 25 pp.

Ammerman, B., J. W. Stringer and Carroll Fackler. 2010. Forestry Emerald Ash Borer Industry Note February 2010: Shipping and Hauling Hardwood Firewood. University of Kentucky, Department of Forestry Extension, Lexington, Kentucky. 2 pp. http://www2.ca.uky.edu/forestryextension/EAB/FORFS1001.pdf. Accessed January 20, 2013.

Andrews, R. A., and J. C. Dammann. 1978. Marketing fuelwood in New Hampshire. Research Report No. 71. University of New Hampshire, Durham. 21 pp.

Baker, Andrew J. 1983. New findings on wood fuel values. American Forests. pp. 45-47, 5152.

Bergman, Richard and John Zerbe. 2008. Primer on wood biomass for energy. USDA Forest Service, State and Private Forestry Technology Marketing Unit. USDA, Forest Service, Forest Products Laboratory, Madison, Wisconsin. $10 \mathrm{pp}$.

Bigsby, K. M., P. C. Tobin and E. O. Sills. 2011. Anthropogenic drivers of gypsy moth spread. Biological Invasions. 13: 2077- 2090.

Boguszewski, Joy. 1983. The trend of domestic fuelwood consumption in West Virginia, 19761991. Doctoral dissertation, West Virginia University.

Boos, Thomas. Pathways of invasion: Road closures in Wisconsin. Wisconsin Department of Natural Resources, Division of Forestry. Presentation. http://www.uprcd.org/\%5C/down loads/pathways_of_invasion_road_closures_in_wi_thomas_boos.pdf. Accessed July 10, 2013.

Borchert, D., L. Newton, T. Culliney, H. Hartzog, R. Ahern, and L. Garrett, 2010. Risk Assessment of the Movement of Firewood within the United States. USDA Animal and Plant Health Inspection Service, Raleigh, North Carolina. 122 pp. 
Bradley, Dennis P. 1987. Wood energy potentials in Northeastern Minnesota. General technical report NC-114. USDA, Forest Service, North Central Forest Experiment Station. 5 pp.

Bragonje, Rich, Matt Borror, Shawn Grushecky and Ben Spong. 2013. West Virginia Forest Products Industry Directory. Appalachian Hardwood Center, West Virginia University, and West Virginia Division of Forestry. $20 \mathrm{pp}$.

Browning S.R., H. Truszczynska, D. Reed and R. H. McKnight. 1998. Agricultural injuries among older Kentucky farmers: The farm family health and hazard surveillance study. American Journal of Industrial Medicine. 33: 341-353.

Butler, J. and Glen H. Hetzel. 1996. Safety with chainsaws. Virginia Cooperative Extension. http://www.nasdonline.org/document/1496/d001289/safety-with-chainsaws.html. Accessed July 8, 2013.

California Firewood Task Force. 2013. Best management practices for arborists and tree care workers: Reducing the spread of invasive insects and pathogens in cut wood. $2 \mathrm{pp}$. http://www.firewood.ca.gov/docs/bmps/ArboristBMPsPub2.pdf. Accessed April 28, 2013.

Campbell, Faith Thompson and Scott E. Schlarbaum. 1994. Fading Forests: North American Trees and the Threat of Exotic Pests. Natural Resources Defense Council, Inc., New York. $128 \mathrm{pp}$.

Campbell, Faith Thompson and Scott E. Schlarbaum. 2002. Fading Forests II: Trading Away North America's Natural Heritage. Healing Stones Foundation. 128 pp.

Carlsson, P. 2003. Att brinna f"or ved [To burn for firewood]. Bachelor Thesis. Department of Culture and Media, Umea University, Umea. 33 pp.

Carpenter, W. S., B. C. Lee, P. D. Gunderson and D. T. Stueland. 2002. Assessment of personal protective equipment use among Midwestern farmers. American Journal of Industrial Medicine 42: 236-247.

Cole, Arthur H. 1970. The mystery of fuel wood marketing in the United States. The Business History Review. 44(3): 339-359.

Colorado Department of Agriculture. 2011. Best Management Strategies for movement and use of firewood in Colorado. http://www.colorado.gov. Accessed April 14, 2013.

Consumer Product Safety Commission National Electronic Injury Surveillance System. 2012. NEISS Data Highlights. 8 pp. http://www.cpsc.gov/Global/Neiss_prod/2012NeissData Highlights.pdf. Accessed October 16, 2013.

Dammann, J. C., and R. A. Andrews. 1979. Economies in fuelwood supply firms in New Hampshire. Research Report No. 76. University of New Hampshire, Durham. 23 pp.

Salant, P. and D. A. Dillman. 1994. How to conduct your own survey. New York: Wiley. 232 pp.

Doyle, Y.G. and R. M. Conroy. 1989. Prevention of timber felling and chainsaw-related accidents in the Republic of Ireland. Accident Analysis \& Prevention. 21(6): 529-534.

Drasdo, Harold. 1969. Margins of Safety. Alpine Journal. pp. 159-168. 
Driscoll, D., G. Milkovits and D. Freudenberg. 2000. Impact and use of firewood in Australia. Commissioned Report by CSIRO Sustainable Ecosystems. 62 pp.

Duerr, Donald A. and Paul A. Mistretta. 2013. Chapter 16: Invasive pests - insects and diseases. The Southern Forest Futures Project General Technical Report SRS-GTR-178. Wear, David N. and John G. Greis, eds. USDA, Forest Service, Southern Research Station, Asheville, North Carolina. pp. 457-508.

Elder, Lee and Bob Gorman. 2009. Western Alaska Firewood Analysis. Article FWM-00130. University of Alaska, Fairbanks Cooperative Extension Service. 4 pp.

Ellis, J. 2008. Firewood initiative of the Continental Dialogue on Non-Native Forest Insects and Diseases. Proceedings of the 2008 Firewood Forum, Northeastern Area, State and Private Forestry. http://na.fs.fed.us/firewood/proceedings/08/proceedings08.shtm. Accessed Februrary 11, 2013.

Evans III, Arthur W., and Richard G. Parker. 1987. Fuelwood processing in New Hampshire becomes a mature industry. Northern Journal of Applied Forestry. 4(2): 76-78.

Evans III, Arthur W. 1985. The production and marketing of fuelwood in New Hampshire: A processors point of view. M.S. Thesis. University of New Hampshire, Durham. 72 pp.

Fairbank, Maslin, Maullin \& Associates. 2006. Key Findings from National Voter Survey on Forest Pests and Pathogens. Report produced for the Nature Conservancy. 2 pp.

Firewood Association of Australia, Inc. Undated. FAA Certified Sustainable Firewood.

Firewood Association of Australia, Inc. Undated. The Code of Practice: Voluntary code of practice for commercial firewood suppliers. http://www.firewood.asn.au/images/stories/ code\%20080214.pdf. Accessed September 20, 2013.

Fischer, V., N. Young, C. Mueller and D. T. Stueland. 2005. Three times the injuries among occasional wood cutters compared to professional loggers: Sample of emergency rooms in central and northern Wisconsin. American Journal of Industrial Medicine. 47(3): 246-253.

Force, J. E. 1985. Firewood use in Idaho: Implications for forest management. Journal of Forestry. pp. 36-39.

Forest*A*Syst. Best Management Practices (BMPs) to prevent the introduction and spread of invasive species. http://www.forestasyst.org/invasive_species.html. Accessed April 28, 2013.

Gardner, W. E. 1995. Woodland owner notes: Producing firewood from your woodlot. Updated Sept. 25, 1995. North Carolina Cooperative Extension. http://www.ces.ncsu. edu/nreos/forest/woodland/won-14.html. Accessed December 12, 2012.

Giacoletto, Mark D. 1982. Market and procurement characteristics of firewood dealers in the United States Forest Service Southern Survey Unit of Illinois, 1981-82. Masters thesis, Southern Illinois University, Carbondale, Illinois. 33 pp.

Gleason, Mark, Donald Lewis, Laura Jesse and Erika Saalau-Rojas. 2011. NCERA-193 Report - Iowa - 2011. pp. 28-30. http://www.lgu.umd.edu/lgu_v2/pages/reportMeet/29841_ min.pdf. Accessed August 18, 2013. 
Goho, Curtis D. 1976. A study of logging residue at woods landings in Appalachia. Research Note NE-219. USDA, Forest Service, Northeastern Forest Experiment Station, Upper Darby, Pennsylvania. 4pp.

Gorman, Bob and Lee Elder. 2009. Service tools for wood heating. Presentation. University of Alaska, Fairbanks Cooperative Extension Service.

Gulland, John. 2013. When to Choose Wood Heat. Mother Earth News. http://www.mother earthnews.com/renewable-energy/wood-heat-zm0z13fmzsor.aspx. Accessed October 9, 2013.

Haack, Robert. 2008. Northern Research Station: Studies Related to Firewood and the Spread of Invasives. pp. 1-3. In: Northeastern area, state and private forestry proceedings of firewood forum 2008. $20 \mathrm{pp}$.

Hall, Charles A. S. and Kent A. Klitgaard. 2011. Energy and the Wealth of Nations: Understanding the Biophysical Economy. Springer, New York, New York: 421 pp.

Hardie, Ian W. and Aziz Abu Hassan. 1986. An econometric analysis of residential demand for fuelwood in the United States, 1980-1981. Forest Science. 32(4): 1001-1015.

Hartkamp, Rens, Bengt Hillring, Warren Mabee, Olle Olsson, Kenneth Skog, Henry Spelter, Johan Vinterback and Antje Wahl. 2009. Continued growth expected for wood energy despite turbulence of the economic crisis: wood energy markets, 2008-2009. In: Forest products annual market review, 2008-2009. United Nations Economic Commission for Europe, Food and Agriculture Organization, Geneva, Switzerland. pp. 97-109.

Hooper, C. A. and T. W. Curtin. 1983. A guide for weekend woodcutters. University of Illinois, Urbana, Illinois. http://www.aces.uiuc.edu/vista/html_pubs/wood/wood.htm. Accessed April 28, 2013.

Houck, J. E., P. E. Tiegs, R. C. McCrillis, C. Keithley, and J. Crouch. 1998. Air emissions from residential heating: The wood heating option put into environmental perspective. In: The Proceedings of a U.S. Environmental Protection Agency and Air Waste Management Association Conference: Emission Inventory: Living in a Global Environment. 1: 373384.

Howard, James L. and David B. McKeever. 2012. U.S. forest products annual market review and prospects, 2008-2012. Research Note FPL-RN-0328. USDA, Forest Service, Forest Products Laboratory. $10 \mathrm{pp}$.

Howard, James L., R. Westby and Kenneth E. Skog. 2010. Criterion 6, Indicator 28: Total and Per Capita Consumption of Wood and Wood Products in Round Wood Equivalents. Research note FPL-RN-0317. USDA, Forestry Service, Forest Products Laboratory. 20 pp. http://originwww.fpl.fs.fed.us/documnts/fplrn/fpl_rn0317.pdf. Accessed August 18, 2013.

Ince, P.J., A. D. Kramp, Kenneth E. Skog, D. Yoo and V. A. Sample. 2011. Modeling future US forest sector market and trade impacts of expansion in wood energy consumption. Journal of Forest Economics. 17: 142-156. 
Indiana Rural Safety And Health Council. 2006. Preventing injuries getting firewood. Purdue University, 2011. https://engineering.purdue.edu/ agsafety/IRSHC/Resources/Safety Snippets/Preventing_Injuries_Getting_Firewood.html. Accessed July 8, 2013.

Jacobi, William R., J. G. Hardin, B. A. Goodrich and C. M. Cleaver. 2012. Retail Firewood Can Transport Live Tree Pests. Journal of Economic Entomology. 105(5): 1645-1658.

Jacobi, William R. 2007. Pathways and Risk Assessment of Emerald Ash Borer Movement into and Within the Western United States. Colorado State University, Fort Collins, Colorado. $65 \mathrm{pp}$.

Jacobi, William, Christy Cleaver, Betsy Goodrich and Janet Hardin. 2011. Firewood Transport of Tree Insects and Diseases. $19 \mathrm{pp}$. Presentation. http://www.continentalforest dialogue.org/events/dialogue/2011-10-05/presentations/04-Jacobi.pdf. Accessed February 11, 2013.

Jacobi, William, Christy Cleaver, Meg Dudley, Annie Marie Casper, Rebecca Powel, Dan West and Javier Mercado. 2011. Forest and Shade Tree Disease Studies. Colorado State University, Fort Collins, Colorado. 3 pp.

Kansas Department of Agriculture. 2007. Firewood survey methods and results. Kansas Department of Agriculture. http://webcache.googleusercontent.com/search?q=cache: EHuM-MRQ4QgJ:www.ksda.gov/includes/document_center/plant_protection/Insect _Survey_Reports/Firewoodsurvey.pdf $+\& \mathrm{~cd}=1 \& \mathrm{hl}=\mathrm{en} \& \mathrm{ct}=\mathrm{clnk} \& \mathrm{gl}=\mathrm{us}$. Accessed October 28, 2013.

Kays, Johnathan S. 2012. A prospectus for advancing biomass thermal energy in Maryland developed by the Maryland Wood Energy Coalition. Maryland Wood Energy Coalition. 20 pp. http://pelletheat.org/wp-content/uploads/2010/01/Maryland-Wood-EnergyProspectus.pdf. Accessed February 11, 2013.

Klen, T. K. and S. Vayrynen. 1984. The role of personal protection in the prevention of accidental injuries in logging work. Journal of Occupational Accidents. 6: 263-275.

Koning, Jr., John W. 1984. Revolution on the farm woodlot- low grading. Woodland Management. 5(2): 8-9.

Koning, Jr., John W. and Kenneth E. Skog. 1987. Use of wood energy in the United States- An opportunity. Biomass. 12: 27-36.

Kovacs, Kent F., Robert G. Haight, Deborah G. McCollough, Rodrigo J. Mercader, Nathan W. Siegert and Andrew M. Liebhold. 2010. Cost of potential emerald ash borer damage in U.S. communities, 2009-2019. Ecological Economics. 69: 569-578.

Levan, Susan L. 1998. Biomass utilization for forest health and community development. In: Bioenergy '98: Expanding bioenergy partnerships. USDA, Forest Service, Forest Product Laboratory, Madison, Wisconsin. pp. 1140-1150.

Lichty, R. W., D. Bradley and D. J. McMillan. 1987. Economic impact of substituting local wood energy for imported fossil fuels. In: USDA Forest Service general technical report NC-114. North Central Forest Experiment Station. pp. 60-65.

Lindroos, Ola. 2007. Efficiency and Safety in Self-employed Family Forestry. Doctoral Thesis. Swedish University of Agricultural Sciences, Umea, Sweden. 42 pp. 
Lindroos, Ola. 2011. Residential use of firewood in Northern Sweden and its influence on forest biomass resources. Biomass and Bioenergy. 35: 385-390.

Lindroos, Ola, E. Wilhelmson Aspman, G. Lidestav and G. Neely. 2008. Accidents in Family Forestry's Firewood Production. Accident Analysis and Prevention. 40: 877-886.

Lindroos, Ola and Lage Burström. 2010. Accident rates and types among self-employed private forest owners. Accident Analysis and Prevention. 42(6): 1729-1735.

Lipfert, F. W., and J. L. Dungan. 1983. Residential Firewood use in the United States. Science. 219: $1425-1427$.

MacIntyre, Doreen L. 2007. Firewood Marketing Study Report. A Northern WoodHeat project, Scotland. $124 \mathrm{pp}$.

Maine Forest Service Department of Conservation. 2012. Cutting firewood on your woodlot. 3 pp.

Marsinko, Allen P. C. 1984. Firewood production and retailing for extra income: A market analysis. Journal of Arboriculture. 10(6): 178-180.

Marsinko, Allen P.C., Douglas R. Phillips, and H. Ken Cordell. 1984. Determining residential firewood consumption. Environmental Management. 8(4): 359-366.

Marsinko, Allen P. C. and T. E. Wooten. 1983. Pickup trucks as units for measuring firewood. Forest Products Research Society Technical Note. Forest Products Journal. 33(1): 4344.

McKeever, David B. and Cherilyn A. Hatfield. 1984. Trends in the production and consumption of major forest products in the United States. USDA Forest Products Laboratory Resource Bulletin FPL-14, Madison, Wisconsin. 59 pp.

McKeever, David B., P. J. Ince, J. L. Howard, H. N. Spelter and A. T. Schuler. 2012. Status and Trends for the U.S. Forest Products Sector: A Technical Document Supporting the Forest Service 2010 RPA Assessment. Gen. Tech. Rep. FPL-GTR-207. Tappi Journal. 35 pp.

Michigan State University. http://www.emeraldashborer.info. Accessed May 23, 2013.

Minnesota Department of Agriculture. 2013. Firewood Alert: important information for those who sell firewood. http://www.mda.state.mn.us/plants/pestmanagement/firewood/ firewood-dealers.aspx. Accessed February 11, 2013.

Model Forest of Newfoundland and Labrador. 2011. Domestic woodcutting guide: Best management practices in Newfoundland and Labrador. Version 2: $12 \mathrm{pp}$. http://issuu.com/modelforestnl/docs/domestic_woodcutting_guide. Accessed July 10, 2013.

Mooney, H.A. and E.E. Cleland. 2001. The evolutionary impact of invasive species. Proc. National Academy of Science, USA. 98: 5446-5451.

National Firewood Association. 2013. NFA member guidelines. https://nationalfirewoodassociation.org/guidelines. Accessed August 15, 2013.

National Firewood Task Force. 2010. National Firewood Task Force Recommendations. 21 pp. 
Neely, G. \& E. Wilhelmson. 2006. Self-reported incidents, accidents, and use of protective gear among small-scale forestry workers in Sweden. Safety Science. 44(8): 723-732.

New Hampshire Department of Revenue Administration. Undated. Formulas for Conversion. 1 pp. http://www.revenue.nh.gov/munc_prop/timber/documents/converformulas.pdf. Accessed October 28, 2013.

Nicholls, David and Tom Miles. 2009. Cordwood energy systems for community heating in Alaska- an overview. General Technical Report PNW-GTR-783. USDA, Forest Service. $18 \mathrm{pp}$.

Nord-Larsen, Thomas, Andreas Bergstedt, Ole Farver and Niels Heding. 2011. Drying of firewood- the effect of harvesting time, tree species and shelter of stacked wood. Biomass and Bioenergy. 35: 2993-2998.

Nybark, E., A. Lunnan, J. I. Jenssen and Pablo Crespell. 2012. The importance of social networks in the Norwegian firewood industry. Biomass and Bioenergy. Article in press. http://dx.doi.org/10.1016/j.biombioe.2012.11.018. Accessed February 11, 2013.

Occupational Safety and Health Administration. Chainsaw safety. https://www.osha.gov/ Publications/3269-10N-05-english-06-27-2007.html. Accessed July 10, 2013.

Ochterski, Jim. 2006. How to Choose Firewood Trees. Forest Connect Fact Sheet Series. Cornell University Cooperative Extension and NY State Department of Environmental Conservation. Kristi L. Sullivan, Peter J. Smallidge and Gary R. Goff, eds. 4 pp.

Ohio Department of Natural Resources. 2004. Private woodlots are a good source of fuel for fireplaces and stoves. Press Release, December 13, 2004. https://www.ohiodnr.com /news/dec04/1213woodlots/tabid/14315/Default.aspx. Accessed April 14, 2013.

Paul, Keryn, Trevor Booth, Anthony Elliot, Tom Jovanovic, Phillip Polglase, and Miko Kirschbaum. 2003. Life cycle assessment of greenhouse gas emissions from domestic woodheating: greenhouse gas emissions from firewood production systems. Report prepared for the Australian Greenhouse Office and Environment Australia by CSIRO Forestry and Forest Products. $25 \mathrm{pp}$.

Pimentel, David, Rodolfo Zuniga and Doug Morrison. 2004. Update on the environmental and economic costs associated with alien-invasive species in the United States. Ecological Economics. 52(3): 273-288.

Petrice, Toby R., and Robert. A. Haack. 2006. Effects of cutting date, outdoor storage conditions, and splitting on survival of Agrilus planipennis (Coleoptera: Buprestidae) in firewood logs. Journal of Economic Entomology. 99: 790-796.

Petrice, Toby R. and Robert A. Haack. 2007. Can Emerald Ash Borer, Agrilus planipennis (Coleopteran: Buprestidae), emerge from logs two summers after infested trees are cut? The Great Lakes Entomologist. 40(1 \& 2): 92-95.

Platt, H. L. 1987. Energy and urban growth- a comparison of Houston and Chicago. The Southwestern Historical Quarterly. 91(1): 1-18. 
Poland, T. M., T. M. Kuhn, C. Zhangjing, A. Diss-Torrance and E. L. Clark. 2008. Evaluation of firewood bagging and vacuum treatment of EAB. In: Mastro, Victor; Lance, David; Reardon, Richard; Parra, Gregory, comps. Emerald ash borer research and development meeting, October 23-24, 2007, Pittsburgh, Pennsylvania. FHTET 2008-07. U.S. Department of Agriculture, Forest Service, Forest Health Technology Enterprise Team, Morgantown, West Virginia. pp. 24-26.

Raitila, Jyrki. 2008. Improving the firewood business in Finland. Quality Wood Project Report WP4/2008. 17 pp.

Reineke, L. H. 1965. Wood fuel preparation. Research note FPL-090. USDA, Forest Service, Forest Products Laboratory, Madison, Wisconsin.

Rutherford, George, Natalie Marcy and Alberta Mills. 2003. Hazard Screen Report: Yard and Garden Equipment (Product Codes 1400-1464). Consumer Products Safety Commission. $20 \mathrm{pp}$.

Sarkar, Ashoke K., and Dipak Ghosh. 2000. Meeting the accessibility needs of rural poor. IASSI Quarterly. 18(2): 5 pp.

Seeland, Tina. 2007. Minnesota Firewood Dealer January 2007 Informal Questionnaire Survey Report. Minnesota Dept of Agriculture. 12 pp.

Skog, K. E. 1989. Fuelwood use in U.S. counties. Research Report 486. Michigan State University Agricultural Exp. Station, East Lansing, Michigan. 35 pp.

Skog, K. E., and I. A. Watterson. 1984. Residential fuelwood use in the United States. Journal of Forestry. 82: 742-747.

Smith, S. 1981. Firewood: Our renewable resource. University of New Hampshire Cooperative Extension. Forest Fact Sheet 8: 4 pp.

Steklenski, Philip G., and John G. Haygreen. 1987. Engineering and economic considerations of wood energy systems using wood chips and pellets. General technical report NC-114. USDA, Forest Service, North Central Forest Experiment Station pp. 77-82.

Taber, D. 1987. Firewood Cutters should adopt safety creed. Agricultural Impact. USDA, National Agricultural Library. 14(11): 3-4.

Taylor, Roger. 2006. Residential Wood Heating Economics. National Renewable Energy Laboratory NAEMI Biomass Training Workshop. Presentation. http://apps1.eere.energy.gov/tribalenergy/pdfs/course_biomass_taylor_econ.pdf. Accessed February 21, 2013.

Tobin, P.C., A. Diss-Torrance, L.M. Blackburn and B.D. Brown. 2010. What does "local" firewood buy you? Managing the risk of invasive species introduction. Journal of Economic Entomology. 103(5): 1569-1576. Entomological Society of America.

U.S. Department of Agriculture, Animal and Plant Health Inspection Service. 2010. Attack of the Invasive Species. http://www.aphis.usda.gov/publications/plant_health/content /printable_version/fs_attack_of_the_invasive_species.pdf. Accessed February 11, 2013.

USDA, APHIS. http://beetlebusters.info. Accessed February 11, 2013. 
USDA, APHIS. State-by-State Information. http://www.dontmovefirewood.org/theproblem/state-state-information/index.html. Accessed January 20, 2013.

USDA, Forest Service. 2013. Chapter 60: Management of specific pests. Forest health protection handbook FSH 3409.11. 9 pp. http://www.fs.usda.gov/Internet/FSE _DOCUMENTS/stelprdb5436350.pdf. Accessed May 23, 2013.

USDA, Forest Service. 1978. Improving your Woodlot by Cutting Firewood. USDA, Forest Service, Northeastern Area State and Private Forestry, Broomall, Pennsylvania. http://www.na.fs.fed.us/spfo/pubs/misc/woodlot/woodlot.htm. Accessed February 21, 2013.

U.S. Department of Labor, Bureau of Labor Statistics. 2013. Consumer Price Index Inflation Calculator. http://data.bls.gov/cgi-bin/cpicalc.pl?cost1 $=85.18 \&$ year $1=1987 \&$ year 2=2013. Accessed October 10, 2013.

U.S. Energy Information Administration. 2013. Short Term Energy Outlook. Updated November 3, 2012. 46 pp. Accessed February 2, 2013.

U.S. EIA. 2012. EIA short-term energy and winter fuels outlook. 26 pp.

University of California. 2012. Best Management Practices (BMPs) for preventing the spread of goldspotted oak borer (GSOB) through the movement of logs and firewood. $4 \mathrm{pp}$. http://www.firewood.ca.gov/docs/bmps/BMPs-GSOB-147218.pdf. Accessed April 25, 2013.

Vermont Division of Forestry. 2001. Firewood facts for producers and retailers. http://www.vtfpr.org/Firewood/ffdealers.cfm. Accessed April 28, 2013.

Warner, K. 2000. Forestry and sustainable livelihoods: what part can forests and forestry play in reducing poverty? Unasylva. 226/227(58): pp. 80-87. 2007.

Weimer, Jen. 2008. Firewood: A major vector of forest pest movement. Presentation given on December 4, 2008 at the workshop on forest health issues in New Hampshire. New Hampshire Division of Forests and Lands. http://extension.unh.edu/resources/files /Resource000906_Rep970.pdf. Accessed February 11, 2013.

Westmoreland County, Pennsylvania. Sale of firewood: Regulations for the Sale of Firewood in Westmoreland County. http://www.co.westmoreland.pa.us/index.aspx?NID=109. Accessed May 23, 2013.

Wharton, E. H. 1991. Fuelwood telephone surveys: how accurate are they? Northern Journal of Applied Forestry. 8(3): 119-122.

Widmann, R. H. 2013. West Virginia's forest resources, 2012. Research Note NRS-192. USDA, Forest Service, Northern Research Station, Newtown Square, Pennsylvania. 4 pp.

Widmann, R. H., G. W. Cook, C. J. Barnet, B. J. Butler, D. M. Griffith, M. A. Hatfield, C. M. Kurtz, R. S. Morin, W. K. Moser, C. H. Perry, R. J. Piva, R. Riemann and C. W. Woodall. 2012. West Virginia's forests 2008. Resource Bulletin NRS-61. USDA, Forest Service, Northern Research Station, Newtown Square, Pennsylvania. 64 pp. 
Wilhelmson, E., D. Staal Wästerlund, L. Burström and Per-Olof Bylund. 2005. Public health effects of accidents in self-employed forestry work. Small-scale Forest Economics, Management and Policy. 4(4): 427-436.

Williamson, Bruce. 2008. Firewood regulation in New York and our "Don't Move Firewood" outreach efforts. New York State Department of Environmental Conservation. Presentation. In: Proceedings, 2008 Firewood Forum: Developing Successful Outreach Strategies, April 15, 2008, Frelinghuysen Arboretum, New Jersey. http://na.fs.fed.us/firewood/proceedings/08/williamson_firewood_april08_comp.pdf. Accessed January 20, 2013.

Zerbe, John and Richard Bergman. 2004. Basic wood energy information. USDA, Forest Service, Forest Products Laboratory, Madison, Wisconsin. 6 pp.

Zerbe, John I. and Kenneth E. Skog. 1988. Sources and uses of wood for energy. In: Proceedings from International Symposium: Energy options for the year 2000: Contemporary concepts in technology and policy. USDA Forest Service, Forest Products Laboratory, Madison, Wisconsin. pp. 1.243-1.254. 


\section{APPENDIX A: Coding of Survey Results}

Table 14. Response codes from two-part survey used to categorize respondents.

\begin{tabular}{ll}
\hline Response Code & Meaning \\
\hline 1 & Positive Contact \\
2 & Refusal \\
3 & No longer selling \\
4 & Never sold \\
5 & One-timer \\
6 & No Contact \\
7 & Disconnect \\
8 & Duplicate (with associated first code) \\
9 & Does not sell in WV \\
\hline Survey Response Code & \\
\hline 1 & Telephone interview only \\
2 & Mail questionnaire only \\
3 & Both surveys \\
\hline
\end{tabular}

\section{Telephone Interview}

Table 15. Number of telephone respondents from various sources.

\begin{tabular}{|c|c|c|}
\hline Source & Count & Percent of All Respondents \\
\hline Craigslist & 39 & $38 \%$ \\
\hline Newspapers (or Trader's magazines) & 35 & $34 \%$ \\
\hline Tree Service (Yellow Pages ${ }^{\mathrm{TM}}$ online) & 5 & $5 \%$ \\
\hline Contacted FOF & 2 & $2 \%$ \\
\hline Public Posts (gas stations, etcetera) & 1 & $1 \%$ \\
\hline Personal Reference & 7 & $7 \%$ \\
\hline Fuel Co & 1 & $1 \%$ \\
\hline AFHA & 10 & $10 \%$ \\
\hline DOF & 1 & $1 \%$ \\
\hline Loggers (Yellow Pages ${ }^{\mathrm{TM}}$ online) & 1 & $1 \%$ \\
\hline
\end{tabular}




\section{Mail Questionnaire}

Table 16. Response rates of individual questions from the mail questionnaire.

\begin{tabular}{|c|c|c|c|c|c|}
\hline Question & $\begin{array}{l}\text { Number of } \\
\text { Responses }\end{array}$ & Question & $\begin{array}{l}\text { Number of } \\
\text { Responses }\end{array}$ & Question & $\begin{array}{l}\text { Number of } \\
\text { Responses }\end{array}$ \\
\hline 1 & 41 & 23 & 41 & 43 & 42 \\
\hline 2 & 42 & 24 & 40 & 44 & 42 \\
\hline 3 & 40 & 25 & 42 & 45 & 42 \\
\hline $4 \mathrm{~A}$ & 42 & 26 & 39 & 46 & 22 \\
\hline $4 B$ & 42 & 27 & 41 & 47 & 42 \\
\hline $4 C$ & 42 & 28 & 38 & 48 & 42 \\
\hline $4 \mathrm{D}$ & 42 & 29 & 38 & 49 & 42 \\
\hline $4 \mathrm{E}$ & 40 & 30 & 41 & 50 & 42 \\
\hline $4 \mathrm{~F}$ & 42 & 31 & 42 & $51 \mathrm{~A}$ & 42 \\
\hline 5 & 41 & 32 & 23 & $51 \mathrm{~B}$ & 42 \\
\hline 6 & 42 & 33 & 37 & $51 \mathrm{C}$ & 42 \\
\hline 7 & 39 & 34 & 41 & $51 \mathrm{D}$ & 42 \\
\hline 8 & 38 & $35 \mathrm{~A}$ & 41 & $51 \mathrm{E}$ & 42 \\
\hline 9 & 41 & $35 \mathrm{~B}$ & 41 & $51 \mathrm{~F}$ & 41 \\
\hline 10 & 41 & $35 \mathrm{C}$ & 41 & $51 \mathrm{G}$ & 40 \\
\hline 11 & 41 & $35 \mathrm{D}$ & 41 & $51 \mathrm{H}$ & 40 \\
\hline 12 & 41 & $35 \mathrm{E}$ & 41 & 52 & 41 \\
\hline 13 & 41 & $35 \mathrm{~F}$ & 40 & 53 & 36 \\
\hline 14 & 40 & $35 \mathrm{G}$ & 41 & 54 & 40 \\
\hline 15 & 42 & $35 \mathrm{H}$ & 41 & 55 & 42 \\
\hline 16 & 42 & 36 & 42 & 56 & 42 \\
\hline 17 & 42 & 37 & 42 & 57 & 42 \\
\hline 18 & 37 & 38 & 40 & 58 & 42 \\
\hline 19 & 40 & 39 & 41 & 59 & 41 \\
\hline 20 & 36 & 40 & 41 & 60 & 38 \\
\hline 21 & 41 & 41 & 42 & & \\
\hline 22 & 42 & 42 & 39 & & \\
\hline
\end{tabular}


Table 17. Number of mail questionnaire respondents from various sources.

\begin{tabular}{lc}
\hline Source & Percent of All Mail Respondents \\
\hline Craigslist & $40 \%$ \\
Newspapers (or Trader's mags) & $33 \%$ \\
Tree Service (Yellow Pages $^{\mathrm{TM}}$ online) & $2 \%$ \\
Contacted FOF & $2 \%$ \\
Public Posts (gas stations, etc) & $0 \%$ \\
Personal Reference & $10 \%$ \\
Fuel Co & $0 \%$ \\
AFHA & $10 \%$ \\
DOF & $2 \%$ \\
Loggers (Yellow Pages ${ }^{\mathrm{TM}}$ online) & $0 \%$ \\
\hline
\end{tabular}


Table 18. West Virginia and out-of-state counties represented by mail questionnaire respondents.

\begin{tabular}{llc}
\hline County & State & Percent of All Mail Respondents \\
\hline Monongalia & WV & $17 \%$ \\
Raleigh & WV & $12 \%$ \\
Greenbrier & WV & $7 \%$ \\
Harrison & WV & $7 \%$ \\
Kanawha & WV & $7 \%$ \\
Fayette & WV & $5 \%$ \\
Jackson & WV & $5 \%$ \\
Marion & WV & $5 \%$ \\
Pocahontas & WV & $5 \%$ \\
Roane & WV & $5 \%$ \\
Upshur & WV & $5 \%$ \\
Boone & WV & $2 \%$ \\
Jefferson & WV & $2 \%$ \\
Lincoln & WV & $2 \%$ \\
Preston & WV & $2 \%$ \\
Randolph & WV & $2 \%$ \\
Summers & WV & $2 \%$ \\
Wood & WV & $2 \%$ \\
\hline Out-of-state & & $2 \%$ \\
\hline Fauquier & VA & \\
Bland & & $2 \%$ \\
\hline & & \\
\hline
\end{tabular}


Table 19. Coding for Question 1 (origin of involvement in the industry) of the mail questionnaire.

\begin{tabular}{ll}
\hline Code & Meaning \\
\hline 1 & Clearing land for development/farm \\
2 & Personal use \\
3 & Supplemental income \\
4 & Property Maintenance (farm, fence rows, woodlot) \\
5 & Tree removal services (handyman or actual company) \\
6 & Logging residue \\
7 & Help family/friends/those in need \\
8 & Tradition (family) \\
9 & Exercise \\
10 & Landscaping business \\
\hline
\end{tabular}

Table 20. Coding for Question 18 (delivery charges) of the mail questionnaire.

\begin{tabular}{ll}
\hline Code & Meaning \\
\hline 1 & By load (flat rate) \\
2 & Mileage \\
3 & None/included \\
\hline
\end{tabular}

Table 21. Coding for Question 21 (discounts offered for customer pickup) of the mail questionnaire.

\begin{tabular}{ll}
\hline Code & Meaning \\
\hline 1 & Flat rate deduction \\
2 & Varies by volume sold \\
3 & Delivery charge removed (gas \$) \\
4 & Unspecified \\
\hline
\end{tabular}


Table 22. Coding for Question 42 (time of day firewood typically produced) of the mail questionnaire.

\begin{tabular}{lll}
\hline Code & Category & Time \\
\hline 1 & 1 & $6 \mathrm{a}-12 \mathrm{p}$ \\
2 & 2 & $12 \mathrm{p}-6 \mathrm{p}$ \\
3 & 3 & $6 \mathrm{p}-6 \mathrm{a}$ \\
4 & $1+2$ & $6 \mathrm{a}-6 \mathrm{p}$ \\
5 & $1+3$ & $6 \mathrm{a}-12 \mathrm{p}$ AND $6 \mathrm{p}-6 \mathrm{a}$ \\
6 & $2+3$ & $12 \mathrm{p}-6 \mathrm{a}$ \\
7 & $1+2+3$ & ALL DAY \\
\hline
\end{tabular}

Table 23. Coding for Question 5 of the telephone interview and Question 47 of the mail questionnaire (most common injury); these were combined to form two-digit codes.

\begin{tabular}{llcl}
\hline Code & Location on Body & Code & Type of Injury \\
\hline 1 & Hand & 1 & Smashing/brusing, pinching \\
2 & Legs & 2 & Bone break \\
3 & Shoulder/back & 3 & Muscular (tearing of tendons/ligaments, beyond sore) \\
4 & Feet & 4 & Sore/aching \\
5 & Non-specified & 5 & Lacerations/cuts/scrapes \\
& & 6 & Splinters/blisters \\
\hline
\end{tabular}


Table 24. Coding for Question 50A-C (description of severe injury experienced within the last 12 months that required more than first aid) from the mail questionnaire.

\begin{tabular}{ll}
\hline Code & Location on Body \\
\hline 1 & head \\
2 & torso \\
3 & arm \\
4 & hand \\
5 & leg \\
6 & foot \\
\hline & Type of Injury \\
\hline 1 & bruising/smashing \\
3 & disease/skin reaction \\
\hline & cut/laceration \\
\hline 1 & Activity at time \\
3 & Felling \\
\hline
\end{tabular}




\section{APPENDIX B: Instrument Reliability Testing Results}

\section{Comparison of corresponding answers from both surveys}

Table 25. Reliability comparison analysis of top three customer types reported by the 41 respondents who participated in both surveys.

\begin{tabular}{lcc}
\hline Top Three Customer Types & $\begin{array}{c}\text { Telephone } \\
\text { Interview }\end{array}$ & $\begin{array}{c}\text { Mail } \\
\text { Questionnaire }\end{array}$ \\
\hline Private individuals or homeowners & $100 \%$ & $98 \%$ \\
Small retailers (convenience stores, gas stations, & & \\
farmer's markets) & $12 \%$ & $0 \%$ \\
Public or private parks or campgrounds & $10 \%$ & $5 \%$ \\
\hline
\end{tabular}

Table 26. Reliability comparison analysis of corresponding answers concerning delivery radius, percent income earned from firewood, average percent of firewood or customers in West Virginia and average cubic foot volume estimates for pickup trucks used from the 41 respondents who participated in both surveys. T-tests used were paired two-sample for means $(\mathrm{p}<0.1$ significant).

\begin{tabular}{|c|c|c|c|c|c|}
\hline \multirow[b]{2}{*}{ Average: } & \multicolumn{2}{|c|}{ Mean } & \multirow[b]{2}{*}{ df } & \multirow[b]{2}{*}{ t statistic } & \multirow[b]{2}{*}{$\begin{array}{r}\mathbf{P}(\mathbf{T}<=\mathbf{t}) \\
\text { two-tail }\end{array}$} \\
\hline & $\begin{array}{c}\text { Phone } \\
\text { Interview }\end{array}$ & $\begin{array}{c}\text { Mail } \\
\text { Questionnaire }\end{array}$ & & & \\
\hline Delivery radius & 35.10 & 27.63 & 39 & 1.372 & 0.1779 \\
\hline Cubic foot volume of Truck 1 & 97.06 & 91.49 & 38 & 0.221 & 0.8265 \\
\hline Cubic foot volume of Truck 2 & 53.32 & 24.59 & 38 & 1.182 & 0.2447 \\
\hline $\begin{array}{l}\text { Percent income earned from } \\
\text { firewood }\end{array}$ & 13.13 & 11.83 & 37 & 0.789 & 0.4350 \\
\hline $\begin{array}{l}\text { Percent firewood sold in WV } \\
\text { (interview) \& percent WV customers } \\
\text { (questionnaire) }\end{array}$ & 93.15 & 93.18 & 39 & -0.008 & 0.9938 \\
\hline
\end{tabular}


Table 27. Reliability comparison analysis of units reported being used by respondents that participated in both surveys ( $\mathrm{p}<0.1$ significant).

\begin{tabular}{lccc}
\hline Unit & Telephone Interview & Mail Questionnaire & $\begin{array}{c}\text { McNemar's Test } \\
\text { (Pr > S) }\end{array}$ \\
\hline Truckload 1 & $88 \%$ & $74 \%$ & 0.0588 \\
Truckload 2 & $27 \%$ & $33 \%$ & 0.8182 \\
Cords & $34 \%$ & $28 \%$ & 0.2568 \\
Half cords & $29 \%$ & $26 \%$ & 0.3173 \\
Face cords & $7 \%$ & $8 \%$ & 1.0000 \\
Prepackaged bundles & $7 \%$ & $8 \%$ & 1.0000 \\
Wheelbarrow loads & $5 \%$ & $5 \%$ & 1.0000 \\
Other Unit & $20 \%$ & $18 \%$ & 0.7389 \\
\hline
\end{tabular}

Table 28. Reliability comparison analysis of class topics that respondents who participated in both surveys would be most likely to attend ( $\mathrm{p}<0.1$ significant).

\begin{tabular}{lccc}
\hline Class Topic & $\begin{array}{c}\text { Telephone } \\
\text { Interview }\end{array}$ & Mail Questionnaire & $\begin{array}{c}\text { McNemar's Test } \\
\text { (Pr }>\text { S) }\end{array}$ \\
\hline General Class Interest & $34 \%$ & $56 \%$ & 0.0389 \\
\hline Marketing & $51 \%$ & $41 \%$ & 0.3173 \\
Woodlot Health & $46 \%$ & $61 \%$ & 0.0833 \\
Chainsaw Safety & $56 \%$ & $59 \%$ & 0.7815 \\
Pest \& Disease ID & $71 \%$ & $78 \%$ & 0.2568 \\
Accounting & $32 \%$ & $33 \%$ & 1.0000 \\
Taxes & $39 \%$ & $31 \%$ & 0.3173 \\
\hline
\end{tabular}


Table 29. Reliability comparison analysis of the most common injuries reported by respondents who participated in both surveys.

\begin{tabular}{lcc}
\hline Most Common Injury (Location/Type) & Telephone Interview & Mail Questionnaire \\
\hline Hands/Smashing, bruising or pinching & $29 \%$ & $24 \%$ \\
Legs/Smashing, bruising or pinching & $15 \%$ & $10 \%$ \\
Shoulders or back/Smashing, bruising or & $10 \%$ & $2 \%$ \\
pinching & $10 \%$ & $2 \%$ \\
Feet/Bone breaks & $7 \%$ & $2 \%$ \\
Hands/Bone breaks & $5 \%$ & $17 \%$ \\
Unspecified/Sore or aching & $5 \%$ & $7 \%$ \\
Feet/Smashing, bruising or pinching & $2 \%$ & $7 \%$ \\
Unspecified/Smashing, bruising or pinching & $2 \%$ & $5 \%$ \\
Unspecified/Splinters or blisters & $2 \%$ & $2 \%$ \\
Legs/Lacerations, cuts or scrapes & $2 \%$ & $0 \%$ \\
Shoulders or back/Sore or aching & $2 \%$ & $0 \%$ \\
Hands/Splinters or blisters & $2 \%$ & $0 \%$ \\
Unspecified/Lacerations, cuts or scrapes & $2 \%$ & $0 \%$ \\
Hands/Lacerations, cuts or scrapes & $2 \%$ & $0 \%$ \\
Unspecified/Muscular (tearing of & & \\
tendons/ligaments, beyond sore) & &
\end{tabular}

\section{Comparison of telephone-only responses to mail questionnaire responses}

Table 30. Reliability comparison analysis of the top three customer types reported by telephone interview-only respondents and questionnaire respondents.

\begin{tabular}{lcc}
\hline Top Three Customer Types & Telephone Interview Only & Mail Questionnaire \\
\hline Private individuals or homeowners & $98 \%$ & $100 \%$ \\
Public or private parks or campgrounds & $18 \%$ & $5 \%$ \\
Small retailers (convenience stores, gas & $15 \%$ & $0 \%$ \\
stations, farmer's markets) & & \\
\hline
\end{tabular}


Table 31. Reliability comparison analysis of telephone interview-only and questionnaire respondents concerning delivery radius, percent income earned from firewood and average percent of firewood sold or customers serviced in West Virginia T-tests used were two-sample assuming unequal variances ( $\mathrm{p}<0.1$ significant).

\begin{tabular}{|c|c|c|c|c|c|}
\hline \multirow[b]{2}{*}{ Average: } & \multicolumn{2}{|c|}{ Mean } & \multirow[b]{2}{*}{ df } & \multirow[b]{2}{*}{ t statistic } & \multirow[b]{2}{*}{$\begin{array}{l}\mathrm{P}(\mathrm{T}<=\mathrm{t}) \\
\text { two-tail }\end{array}$} \\
\hline & $\begin{array}{c}\text { Phone } \\
\text { Interview } \\
\text { Only }\end{array}$ & $\begin{array}{c}\text { Mail } \\
\text { Questionnaire }\end{array}$ & & & \\
\hline Delivery radius & 35.85 & 26.95 & 94 & 1.912 & 0.0589 \\
\hline Cubic foot volume of Truck 1 & 120.29 & 91.49 & 95 & 1.202 & 0.2323 \\
\hline Cubic foot volume of Truck 2 & 50.93 & 53.32 & 70 & -0.099 & 0.9213 \\
\hline $\begin{array}{l}\text { Percent income earned from } \\
\text { firewood }\end{array}$ & 19.02 & 5.79 & 77 & 2.088 & 0.0476 \\
\hline $\begin{array}{l}\text { Percent firewood sold in WV } \\
\text { (interview) \& percent WV customers } \\
\text { (questionnaire) }\end{array}$ & 89.94 & 93.34 & 93 & -0.741 & 0.4604 \\
\hline
\end{tabular}

Table 32. Reliability comparison analysis of units reported being used by telephone interviewonly respondents and those used by questionnaire respondents. Fisher's Exact Test (FET) results where $\mathrm{p}<0.1$ are considered significant.

\begin{tabular}{lccc}
\hline Unit & $\begin{array}{c}\text { Telephone } \\
\text { Interview Only }\end{array}$ & Mail Questionnaire & FET (Pr $<=\mathbf{P})$ \\
\hline Truckload 1 & $92 \%$ & $74 \%$ & 1.0000 \\
Truckload 2 & $31 \%$ & $33 \%$ & 0.3239 \\
Cords & $49 \%$ & $28 \%$ & 0.0890 \\
Half cords & $36 \%$ & $26 \%$ & 0.4850 \\
Face cords & $15 \%$ & $8 \%$ & 0.4876 \\
Prepackaged bundles & $8 \%$ & $8 \%$ & 0.3081 \\
Wheelbarrow loads & $7 \%$ & $5 \%$ & 1.0000 \\
Other Unit & $10 \%$ & $18 \%$ & 0.5710 \\
\hline
\end{tabular}


Table 33. Reliability comparison analysis of classes that telephone-interview only respondents and questionnaire respondents indicated they would be "somewhat likely" or "very likely" to attend.

\begin{tabular}{lccc}
\hline Class Topic & $\begin{array}{c}\text { Telephone Interview } \\
\text { Only }\end{array}$ & Mail Questionnaire & FET (Pr $<=$ P) \\
\hline General Class Interest & $34 \%$ & $59 \%$ & 0.5880 \\
\hline Marketing & $48 \%$ & $46 \%$ & 0.2407 \\
Woodlot Health & $45 \%$ & $51 \%$ & 0.5613 \\
Chainsaw Safety & $45 \%$ & $37 \%$ & 0.7732 \\
Pest \& Disease ID & $48 \%$ & $29 \%$ & 0.0305 \\
Accounting & $30 \%$ & $51 \%$ & 0.0384 \\
Taxes & $27 \%$ & $46 \%$ & 0.7254 \\
\hline
\end{tabular}

Table 34. Reliability comparison analysis of the most common injuries reported by telephone interview-only respondents and questionnaire respondents.

\begin{tabular}{lcc}
\hline Most Common Injury (Location/Type) & $\begin{array}{c}\text { Telephone Interview } \\
\text { Only }(\mathbf{n}=\mathbf{6 1})\end{array}$ & $\begin{array}{c}\text { Mail Questionnaire } \\
\text { (n = 41) }\end{array}$ \\
\hline Hands/Smashing, bruising or pinching & $29 \%$ & $24 \%$ \\
Legs/Smashing, bruising or pinching & $15 \%$ & $10 \%$ \\
Shoulders or back/Smashing, bruising or & $10 \%$ & $2 \%$ \\
pinching & $10 \%$ & $2 \%$ \\
Feet/Bone breaks & $7 \%$ & $2 \%$ \\
Hands/Bone breaks & $5 \%$ & $17 \%$ \\
Unspecified/Sore or aching & $5 \%$ & $7 \%$ \\
Feet/Smashing, bruising or pinching & $2 \%$ & $7 \%$ \\
Unspecified/Smashing, bruising or pinching & $2 \%$ & $5 \%$ \\
Unspecified/Splinters or blisters & $2 \%$ & $2 \%$ \\
Legs/Lacerations, cuts or scrapes & $2 \%$ & $0 \%$ \\
Shoulders or back/Sore or aching & $2 \%$ & $0 \%$ \\
Hands/Splinters or blisters & $2 \%$ & $0 \%$ \\
Unspecified/Lacerations, cuts or scrapes & $2 \%$ & $0 \%$ \\
Hands/Lacerations, cuts or scrapes & $2 \%$ & $0 \%$ \\
Unspecified/Muscular (tearing of & & \\
tendons/ligaments, beyond sore) & & \\
\hline
\end{tabular}




\section{APPENDIX C: Selected Results from Analyses of Sub-groups}

Table 35. Various sub-groups used to compare answers from mail questionnaire respondents using statistical analyses $(\mathrm{p}<0.1$ significant $)$ in order to determine whether certain firewood producers share characteristics that make them more likely to engage in outreach.

\begin{tabular}{lc} 
Sub-group & $(\mathbf{n}=\mathbf{4 2})$ \\
\hline Willing to attain Community Firewood Dealer Certification & $50 \%$ \\
Views firewood production as a hobby & $76 \%$ \\
Between 18 and 40 years of age & $50 \%$ \\
Producing firewood for financial reasons & $67 \%$ \\
Likely to attend four or more classes & $57 \%$ \\
\hline
\end{tabular}

Percent of Mail Respondents

\section{Sub-group Willing to Attain Community Firewood Dealer Certification}

Table 36. Continuous variables examined using two-sample t-tests assuming unequal variances $(\mathrm{p}<0.1$ significant) for mail questionnaire respondents, depending on whether or not they are willing to certify.

\begin{tabular}{lcccccc}
\hline & \multicolumn{3}{c}{ Mean } & & & \\
\cline { 2 - 4 } Average: & Certify & $\begin{array}{c}\text { No } \\
\text { Certify }\end{array}$ & df & t statistic & $\begin{array}{c}\text { P(T }<=\mathbf{t}) \\
\text { two-tail }\end{array}$ \\
\hline Number of years in business & 12.48 & 11.30 & 38 & 0.285 & 0.7772 \\
Distance to harvest & 18.00 & 14.52 & 40 & 0.637 & 0.5279 \\
Delivery radius & 30.48 & 24.52 & 33 & 0.985 & 0.3318 \\
Cord volume sold last year & 42.13 & 39.29 & 31 & 0.077 & 0.9394 \\
Percent income earned from firewood & 19.02 & 5.79 & 24 & 2.088 & 0.0476 \\
Number of future years in business & 13.75 & 11.58 & 35 & 0.524 & 0.6036 \\
Weekly hours spent on harvesting & 10.95 & 8.61 & 38 & 0.637 & 0.5282 \\
Weekly hours spent on accounting & 0.29 & 0.18 & 38 & 0.615 & 0.5422 \\
Weekly hours spent on splitting & 9.00 & 7.34 & 35 & 0.508 & 0.6150 \\
Weekly hours spent on marketing & 0.27 & 0.13 & 37 & 1.160 & 0.2534 \\
Weekly hours spent on delivering & 5.86 & 5.29 & 34 & 0.213 & 0.8326 \\
Fee willing to pay to attend class & 25.14 & 5.56 & 24 & 2.452 & 0.0219 \\
Distance willing to travel to attend class & 35.75 & 25.63 & 38 & 1.083 & 0.2854 \\
\hline
\end{tabular}




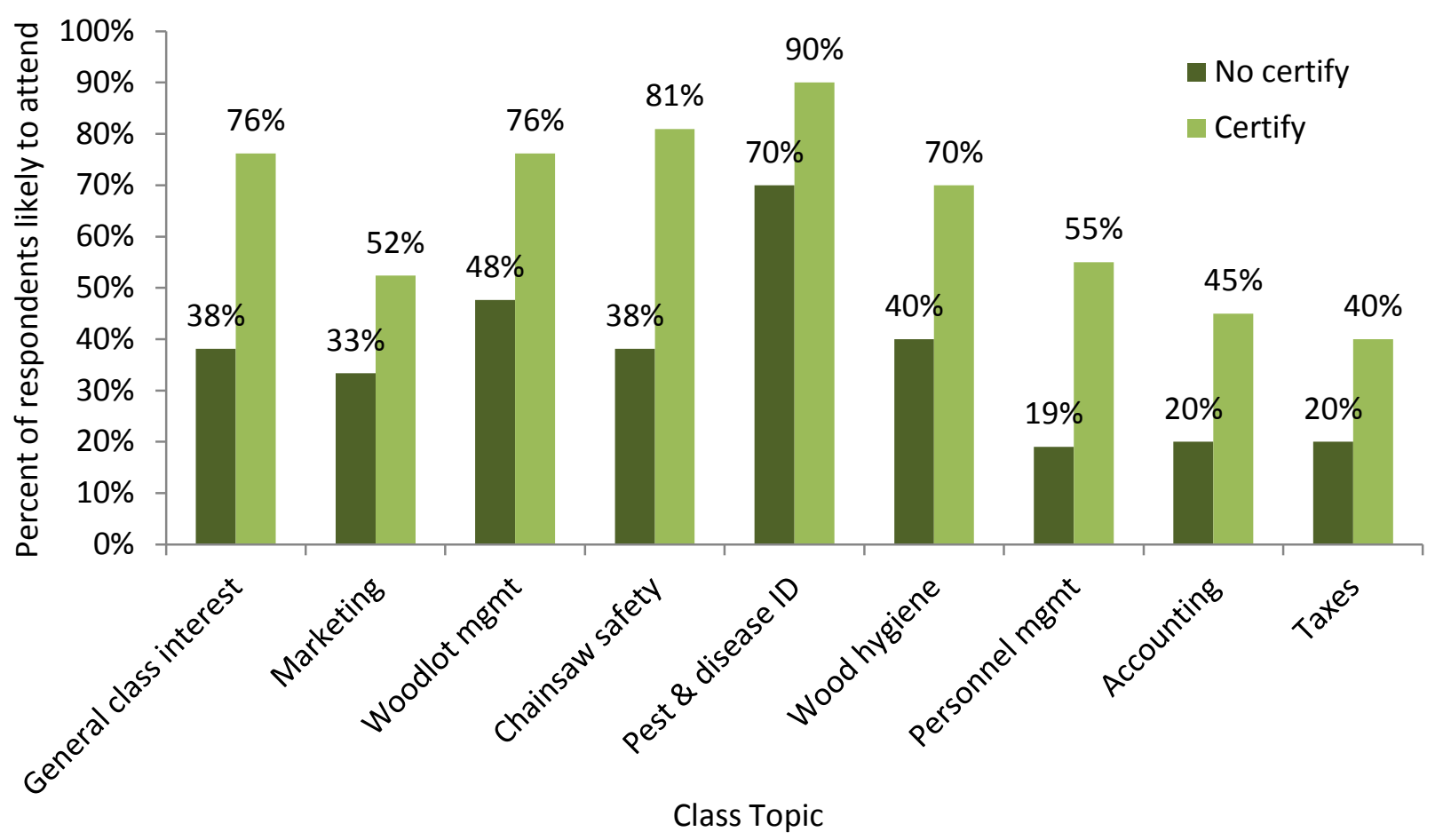

Figure 19. Classes that mail questionnaire respondents are "somewhat likely" or "very likely" to attend, depending on whether or not they are willing to certify. 


\section{Sub-group That Views Firewood Production as a Hobby}

Table 37. Continuous variables examined using two-sample t-tests assuming unequal variances $(\mathrm{p}<0.1$ significant) for mail questionnaire respondents, depending on whether or not they view firewood production as a hobby.

\begin{tabular}{lcccccc}
\hline & \multicolumn{3}{c}{ Mean } & & & \\
\cline { 2 - 4 } Average: & Hobby & Hobby & df & t statistic & $\begin{array}{c}\text { P(T <=t) } \\
\text { two-tail }\end{array}$ \\
\cline { 2 - 5 } Number of years in business & 11.63 & 13.50 & 16 & -0.386 & 0.7046 \\
Distance to harvest & 14.12 & 23.10 & 11 & -1.089 & 0.2995 \\
Delivery radius & 27.50 & 27.50 & 15 & 0.000 & 1.0000 \\
Cord volume sold last year & 14.98 & 118.21 & 8 & -1.521 & 0.1668 \\
Percent income earned from firewood & 10.79 & 19.44 & 11 & -0.954 & 0.3604 \\
Number of future years in business & 12.36 & 13.78 & 12 & -0.263 & 0.7972 \\
Weekly hours spent on harvesting & 9.98 & 9.33 & 15 & 0.159 & 0.8753 \\
Weekly hours spent on accounting & 0.23 & 0.28 & 11 & -0.218 & 0.8314 \\
Weekly hours spent on splitting & 7.24 & 11.56 & 11 & -0.958 & 0.3584 \\
Weekly hours spent on marketing & 0.26 & 0.00 & 30 & 3.480 & 0.0016 \\
Weekly hours spent on delivering & 5.06 & 7.39 & 11 & -0.658 & 0.5239 \\
Fee willing to pay to attend class & 19.04 & 5.75 & 34 & 2.062 & 0.0469 \\
Distance willing to travel to attend class & 30.00 & 32.75 & 13 & -0.219 & 0.8302 \\
\hline
\end{tabular}




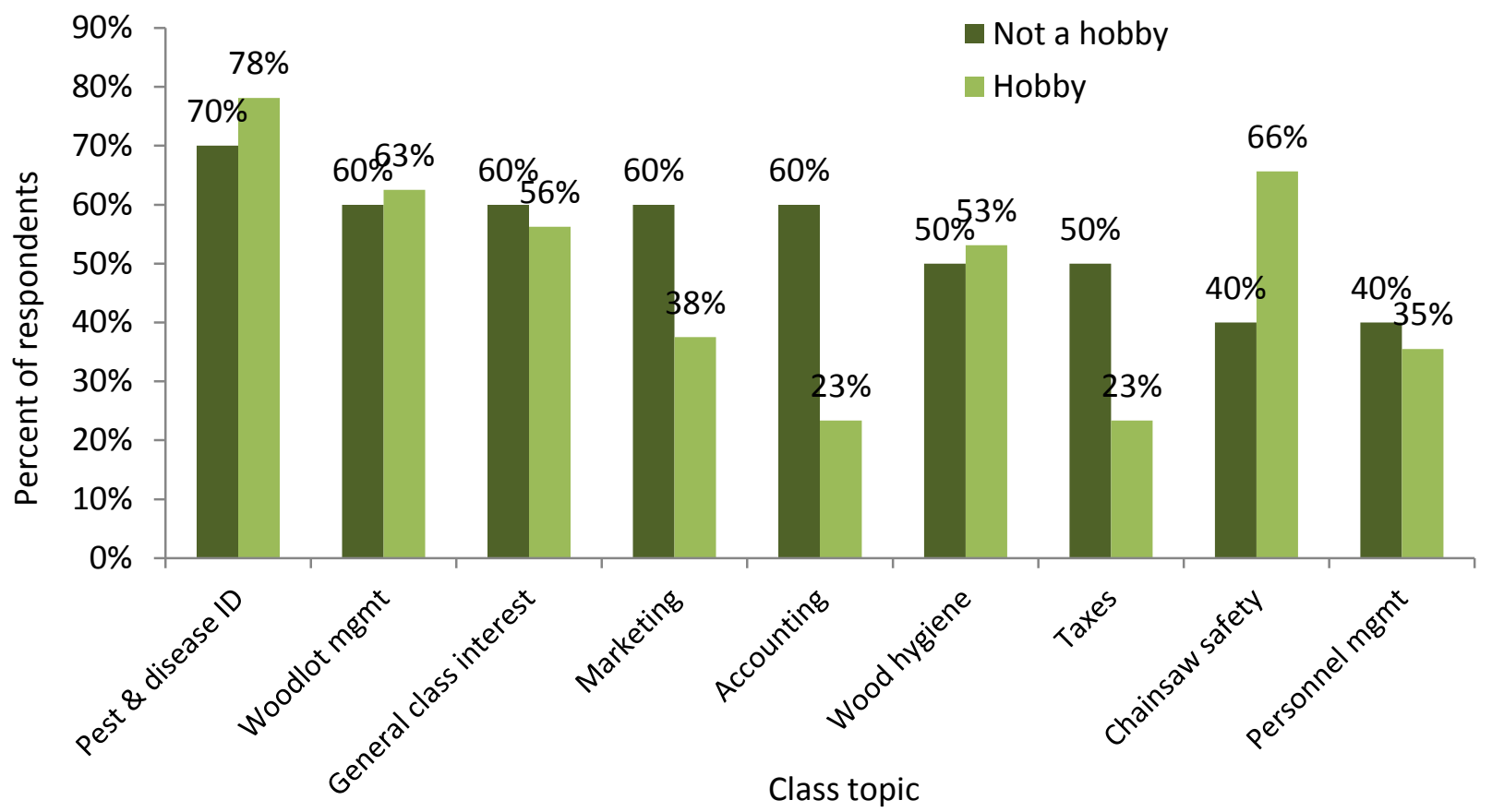

Figure 20. Classes that mail questionnaire respondents are "somewhat likely" or "very likely" to attend, depending on whether or not they view firewood production as a hobby.

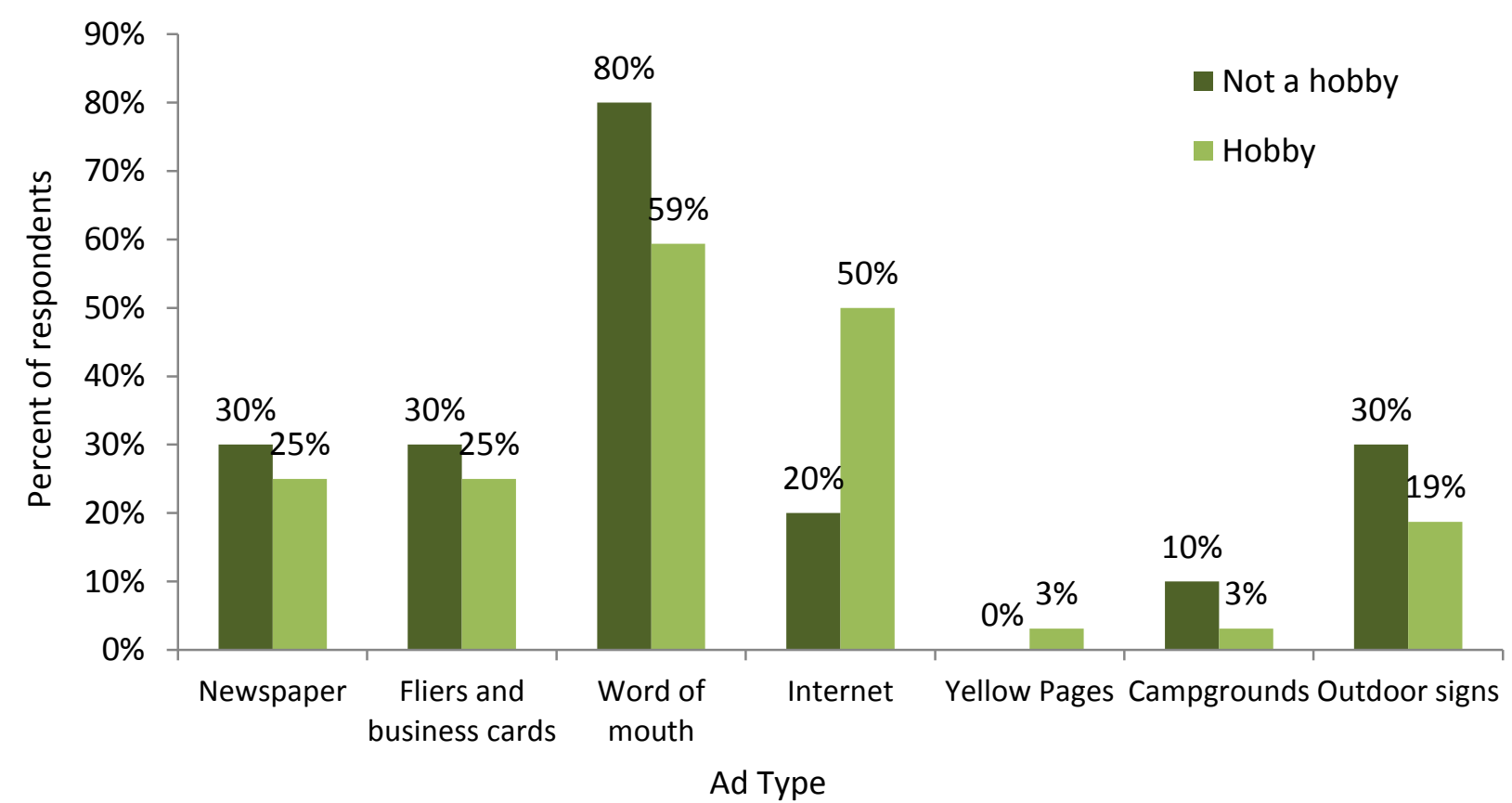

Figure 21. Advertisement methods utilized by mail questionnaire respondents, depending on whether or not they view firewood production as a hobby. 


\section{Sub-group Producing Firewood for Financial Reasons}

Table 38. Continuous variables examined using two-sample t-tests assuming unequal variances $(\mathrm{p}<0.1$ significant) for mail questionnaire respondents, depending on whether or not they are producing firewood for financial reasons.

\begin{tabular}{|c|c|c|c|c|c|}
\hline \multirow[b]{2}{*}{ Average: } & \multicolumn{2}{|c|}{ Mean } & \multirow[b]{2}{*}{ df } & \multirow[b]{2}{*}{ t statistic } & \multirow[b]{2}{*}{$\begin{array}{c}P(T<=t) \\
\text { two-tail }\end{array}$} \\
\hline & $\begin{array}{c}\text { Non- } \\
\text { financial } \\
(n=14)\end{array}$ & $\begin{array}{c}\text { Financial } \\
(\mathbf{n}=\mathbf{2 8})\end{array}$ & & & \\
\hline Number of years in business & 10.39 & 15.15 & 20 & -1.015 & 0.3222 \\
\hline Distance to harvest & 16.53 & 16.12 & 23 & 0.067 & 0.9471 \\
\hline Delivery radius & 20.71 & 30.89 & 32 & -1.754 & 0.0889 \\
\hline Cord volume sold last year & 7.87 & 59.39 & 23 & -1.848 & 0.0776 \\
\hline Percent income earned from firewood & 5.53 & 16.62 & 35 & -1.998 & 0.0535 \\
\hline Number of future years in business & 14.00 & 12.04 & 20 & 0.413 & 0.6843 \\
\hline Weekly hours spent on harvesting & 11.96 & 5.89 & 30 & 1.677 & 0.1038 \\
\hline Weekly hours spent on accounting & 0.27 & 0.18 & 26 & 0.514 & 0.6114 \\
\hline Weekly hours spent on splitting & 8.54 & 7.61 & 21 & 0.250 & 0.8047 \\
\hline Weekly hours spent on marketing & 0.22 & 0.18 & 29 & 0.320 & 0.7511 \\
\hline Weekly hours spent on delivering & 5.44 & 5.86 & 19 & -0.132 & 0.8960 \\
\hline Fee willing to pay to attend class & 18.33 & 12.04 & 13 & 0.695 & 0.0469 \\
\hline Distance willing to travel to attend class & 30.48 & 31.07 & 24 & -0.058 & 0.9546 \\
\hline
\end{tabular}




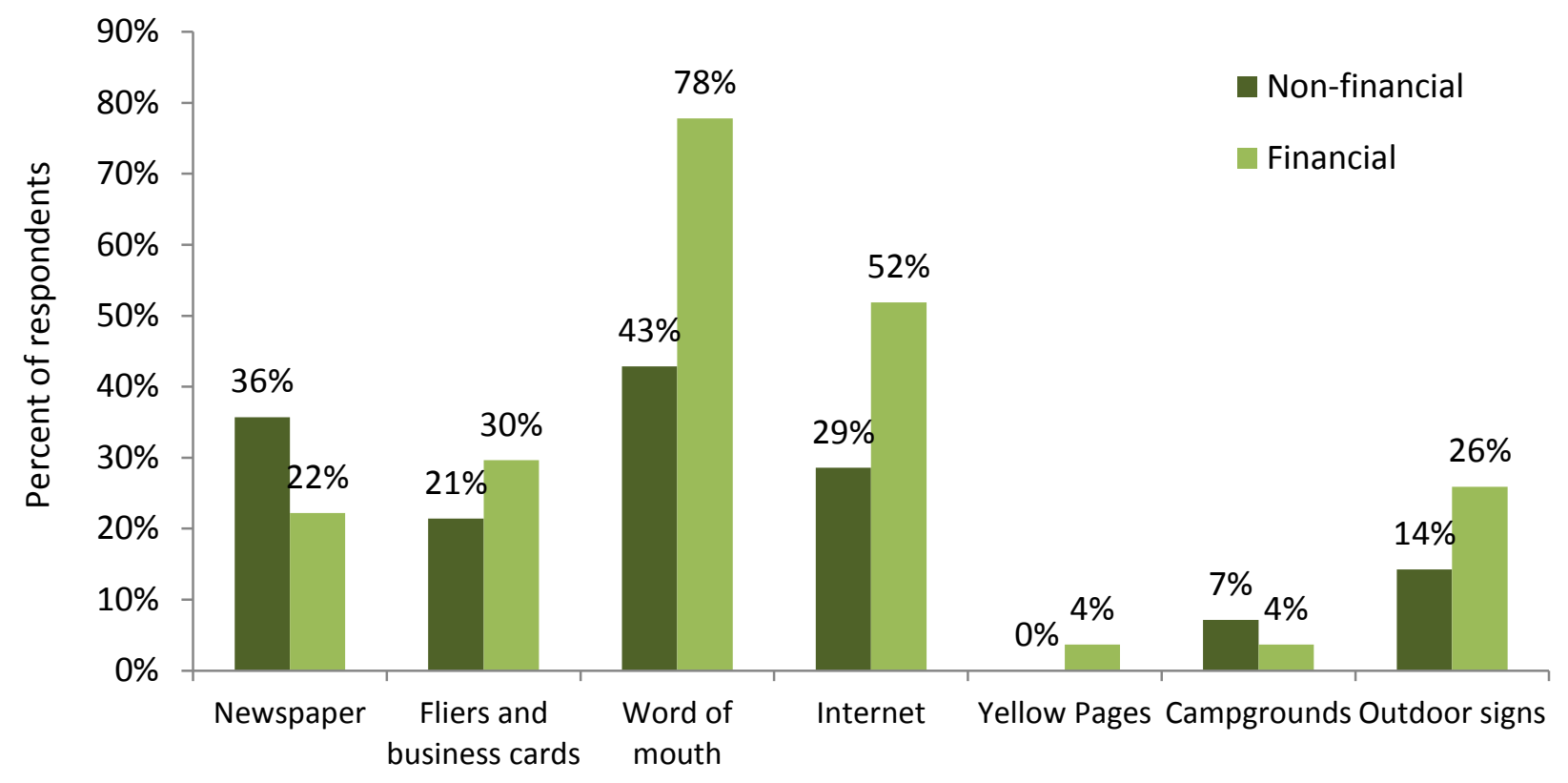

Ad type

Figure 22. Advertisement methods utilized by mail questionnaire respondents, depending on whether or not they are producing firewood for financial reasons. 


\section{Sub-group between 18 and 40 Years of Age}

Table 39. Continuous variables examined using two-sample t-tests assuming unequal variances $(\mathrm{p}<0.1$ significant) for mail questionnaire respondents, depending on whether they are above or below the age of 40 years.

\begin{tabular}{lcccccc}
\hline & \multicolumn{3}{c}{ Mean } & & & \\
\cline { 2 - 5 } Average: & $\begin{array}{c}\mathbf{1 8 - 4 0} \mathbf{y r s} \\
(\mathbf{n}=\mathbf{2 1})\end{array}$ & $\begin{array}{c}>\mathbf{4 0} \mathbf{~ y r s} \\
\mathbf{( n = 2 1 )}\end{array}$ & df & t statistic & $\begin{array}{c}\text { P(T }<=\mathbf{t}) \\
\text { two-tail }\end{array}$ \\
\hline Number of years in business & 5.57 & 18.55 & 24 & -3.543 & 0.0017 \\
Distance to harvest & 14.83 & 17.69 & 40 & -0.523 & 0.6042 \\
Delivery radius & 26.19 & 28.81 & 30 & -0.429 & 0.6709 \\
Cord volume sold last year & 62.31 & 16.74 & 19 & 1.344 & 0.1948 \\
Percent income earned from firewood & 11.25 & 14.23 & 37 & -0.429 & 0.6701 \\
Number of future years in business & 14.55 & 10.74 & 36 & 0.930 & 0.3584 \\
Weekly hours spent on harvesting & 8.67 & 11.13 & 30 & -0.652 & 0.5190 \\
Weekly hours spent on accounting & 0.19 & 0.29 & 37 & -0.596 & 0.5545 \\
Weekly hours spent on splitting & 7.48 & 9.03 & 36 & -0.475 & 0.6375 \\
Weekly hours spent on marketing & 0.18 & 0.24 & 36 & -0.486 & 0.6301 \\
Weekly hours spent on delivering & 4.45 & 6.84 & 32 & -0.901 & 0.3743 \\
Fee willing to pay to attend class & 20.00 & 11.18 & 23 & 0.997 & 0.3292 \\
Distance willing to travel to attend class & 27.98 & 33.68 & 30 & -0.590 & 0.5594 \\
\hline
\end{tabular}




\section{Sub-group Likely to Attend Four or More Classes}

Table 40. Continuous variables examined using two-sample t-tests assuming unequal variances ( $p<0.1$ significant) for mail questionnaire respondents, depending on whether or not they have a general interest in attending workshops.

\begin{tabular}{|c|c|c|c|c|c|}
\hline \multirow[b]{2}{*}{ Average: } & \multicolumn{2}{|c|}{ Mean } & \multirow[b]{2}{*}{ df } & \multirow[b]{2}{*}{ t statistic } & \multirow[b]{2}{*}{$\begin{array}{c}P(T<=t) \\
\text { two-tail }\end{array}$} \\
\hline & Interested & $\begin{array}{c}\text { Not } \\
\text { Interested }\end{array}$ & & & \\
\hline Number of years in business & 12.92 & 10.47 & 37 & 0.598 & 0.5537 \\
\hline Distance to harvest & 20.27 & 10.92 & 40 & 1.840 & 0.0731 \\
\hline Delivery radius & 29.79 & 24.44 & 40 & 0.917 & 0.3644 \\
\hline Cord volume sold last year & 39.43 & 42.69 & 25 & -0.084 & 0.9337 \\
\hline Percent income earned from firewood & 18.94 & 3.44 & 28 & 2.789 & 0.0094 \\
\hline Number of future years in business & 11.87 & 13.88 & 27 & -0.455 & 0.6525 \\
\hline Weekly hours spent on harvesting & 10.17 & 9.34 & 31 & 0.214 & 0.8317 \\
\hline Weekly hours spent on accounting & 0.19 & 0.31 & 20 & -0.656 & 0.5190 \\
\hline Weekly hours spent on splitting & 7.46 & 9.34 & 22 & -0.518 & 0.6098 \\
\hline Weekly hours spent on marketing & 0.21 & 0.20 & 32 & 0.065 & 0.9483 \\
\hline Weekly hours spent on delivering & 5.25 & 6.09 & 25 & -0.295 & 0.7703 \\
\hline Fee willing to pay to attend class & 20.39 & 9.71 & 34 & 1.263 & 0.2150 \\
\hline Distance willing to travel to attend class & 38.69 & 19.85 & 38 & 2.135 & 0.0393 \\
\hline
\end{tabular}




\section{APPENDIX D: Telephone Interview Script}

\section{INTRODUCTION:}

Hello, my name is and I'm calling with the West Virginia Friends of Firewood Network. We found this telephone number on an advertisement in West Virginia for firewood for sale. Is the firewood producer available to talk?

IF WRONG NUMBER, CONFIRM: May I confirm that this telephone number is XXXXXX-XXXX? OK. We will remove you from our list. Thank you for your time. END

[YES] PROCEED TO QUESTION 1

[NO] Is there a better time to call or another way I can reach him or her?

[YES] Great! GET TIME AND CONTACT NAME. Thank you, I look forward to speaking with him/her. Have a nice day! END

[NO] OK. Thank you for your time. Have a nice day. END

1.) Are you the firewood producer?

[YES] PROCEED TO QUESTION 2
[NO] Is the person who produces the firewood available to come to the telephone?

[YES] Great! Thank you! PROCEED TO QUESTION 3

[NO] Is there a better time to call or another way I can reach them (him or her)?

[YES] Great! When is the best time? GET CONTACT NAME AND TIME I look forward to talking to [him/her]- have a nice day! END

[NO] OK. Thank you for your time. END

2.) Do you have a moment to take part in a 5 minute voluntary research interview?

[YES] PROCEED TO QUESTION 4

[NO] Your point of view is very important to us; is there a better time to call?

[YES] Great! When is the best time I can reach you? GET NAME AND TIME. I look forward to talking to you- have a nice day! END

[NO] OK. Would you feel more comfortable completing a mail survey? Your information will only be used for this study and will remain completely confidential.

[YES] Great! GET NAME AND ADDRESS. You should 
receive the questionnaire in the mail within weeks. Thank you very much. Have a nice day! END

[NO] OK. Thank you for your time. Have a nice day. END

3.) ONCE FIREWOOD PRODUCER ON TELEPHONE: Hello, my name is and I'm calling with the Friends of Firewood Network. We are conducting a research study in order to familiarize ourselves with the range of practices of firewood dealers in West Virginia. Do you have a moment to take part in a quick telephone interview?

\section{[YES] PROCEED TO QUESTION 4}

[NO] Your point of view is very important to us; is there a better time to call?

[YES] Great! When is the best time I can reach you? GET CONTACT NAME AND TIME. I look forward to talking to you- have a nice day! END

[NO] OK. Would you feel more comfortable completing a mail questionnaire? Your information will only be used for this study and will remain completely confidential.

[YES] Great! GET MAILING ADDRESS AND NAME Thank you very much. You should receive the questionnaire in the mail within two weeks. Have a nice day! END

[NO] OK. Thank you for your time. Have a nice day. END

4.) Great! I'm going to read you a quick description of this interview:

This interview will only take about 5 minutes. I will be asking you 9 questions that will help us better understand your role in the West Virginia firewood industry. Your identity will remain confidential and only your responses will be used for our study. You may skip any questions that you do not want to answer and may end the interview at any time. Do I have your permission to proceed?

[YES] Great!

PROCEED TO INTERVIEW
[NO] I understand that your time is important. Your opinion is essential to this study. Would you be interested in completing a mail questionnnaire instead?

[YES] Great! GET MAILING ADDRESS AND NAME You should receive the questionnaire in the mail within two weeks. Thank you for your time. Have a nice day. END

[NO] OK. Thank you for your time. Have a nice day. END 


\section{BEGIN INTERVIEW HERE:}

IF AT ANY TIME THE RESPONDENT ASKS A QUESTION ABOUT THE NATURE

OF THE PROJECT: I have a short write-up that I am going to read to you:

We are conducting a research survey through the West Virginia University Extension Service so we can learn about the range of practices of firewood producers in West Virginia. The information provided will be used to develop a collaborative network of firewood producers and dealers as well as a variety of educational classes. We are raising awareness of firewood as a main source of movement of tree pests and diseases and the methods by which we may minimize these threats. We recognize that the firewood industry is important in West Virginia and education is one key to maintaining the health of both the firewood industry and West Virginia woodlands.

IF AT ANY TIME RESPONDENT ASKS WHY THEY WERE CHOSEN: Your telephone number has been chosen to be included in the study because it was associated with firewood for sale in West Virginia. IF RESPONDENT ASKS ABOUT SOURCE OF TELEPHONE NUMBER, MENTION THAT THEY WERE PULLED FROM A VARIETY OF SOURCES INCLUDING INTERNET, YELLOW PAGES AND LOCAL ADS Your opinions are very important to the development of the Friends of Firewood network because they will help us create educational classes to meet the diverse needs of West Virginia firewood producers. We are also inviting you to become part of our collaborative online network.

If you have further questions about this survey, I would be happy to provide you with a telephone number for you to call to get more information.

DAVE MCGILL: (304) 293-5930

IRB OFFICE: (304) 293-7073

Q1 I am going to read a list of firewood purchasers and ask which you sell your firewood to. Please respond yes or no to each.

A Private individuals or homeowners

B Public or private parks or campgrounds

C Large Retailers (such as Walmart, Home Depot, grocery stores or Lowe's)

D Small Retailers (such as convenience stores, gas stations or farmer's markets)

E Other (Please describe):

Q2 Do you deliver your firewood to your customers?

1 YES PROCEED TO QUESTION A

2 NO PROCEED TO QUESTION 3

QA What is the farthest distance in miles that you drive to deliver firewood to your customers? MILES 
QB What proportion of your firewood do you sell in West Virginia? $\%$

Q3 I am going to read a list of firewood units and ask you in which units you sell your firewood. Please respond yes or no to each.

A By the Truck Load:

Please describe the length, width and depth of the bed of the largest truck you use to deliver:

Please describe the length, width and depth of the bed of the secondlargest truck you use to deliver:

B By Cord

C By $\underline{1 / 2}$ Cord

D By Face Cord

E By Pre-Packaged Bundles

F By Wheelbarrow Load

G Other:

Q4 What percentage of your personal individual income comes from your firewood business? PERCENT (\%)

Q5 What is the most common injury you experience in the process of producing firewood?

Q6 On a scale of 1 to 4, how likely would you be to attend the following workshops for firewood producers, with 1 being "Completely Unlikely" and 4 being "Very Likely?"

A Marketing (for example, effective advertising, decreasing costs and increasing profits)

B Techniques for improving the health of the woodlands where you collect your firewood

C Chainsaw safety practices

D Pest and disease identification

E Accounting techniques

F Tax preparation

Q7 Are there any other educational topics related to firewood that you would be interested in that I haven't mentioned?

1 YES Please describe:

2 NO 
Q8 Do you know of any other local firewood producers that we might call to alert to this project?

\section{YES GET NAME AND CONTACT INFO}

2 NO

Q9 We appreciate the opportunity that you have given us to interview you. To gather further information for our study, we are also conducting a mail questionnaire in the coming few weeks- would you be willing to participate if we offered you a complimentary Friends of Firewood Network bumper sticker? Once again your information would be kept completely confidential.

[YES] Great! GET MAILING ADDRESS You should receive the questionnaire in the mail within two weeks. Thank you again for taking part in our research study. Have a nice day! END

[NO] OK. Would you be interested in receiving invitations to future workshops via email or postcard?

[YES] Great! GET MAILING AND/OR EMAIL ADDRESS

Thank you again for taking part in our research study.

Have a nice day! END

[NO] OK. Thank you for allowing us to interview you. Have a nice day. END 


\section{APPENDIX E: Mail Questionnaire Cover Letter}

Date

Dear Firewood Producer:

Enclosed is a questionnaire designed to help researchers, agency professionals, and most importantly, other firewood producers, strengthen the firewood industry in West Virginia. Your knowledge and opinions will provide valuable information toward supporting the firewood industry while preserving the health of West Virginia woodlands.

Please consider contributing your experience and knowledge to this research effort. Your participation in this survey is voluntary and you can quit at any time without any penalty. You do not have to answer all of the questions, but any experience and knowledge you provide will contribute to the success of this project. If you do not wish to participate, please let us know by returning the questionnaire, blank or with a note, in the self-addressed, stamped envelope provided.

Any information that you provide will be confidential; only summaries will be reported in which no individual's answers can be identified. When you return your completed questionnaire, your name will be deleted from the mailing list and will never be connected to your answers in any way. West Virginia University's Institutional Review Board acknowledgement of this study is on file.

If you have any further questions, please feel free to contact us at any of the telephone numbers below. Thank you in advance for your participation. It is with your help that we can create a sustainable, thriving firewood industry in West Virginia.

Sincerely,

Dave McGill, Principal Investigator

Professor/ Extension Specialist

Forest Resources Management

(304) 293-5930
Elizabeth Basham

Graduate Research Assistant and Coordinator Friends of Firewood Network

(304) 212-4535 
APPENDIX F: Mail Questionnaire

2012 Survey of West Virginia Firewood Producers

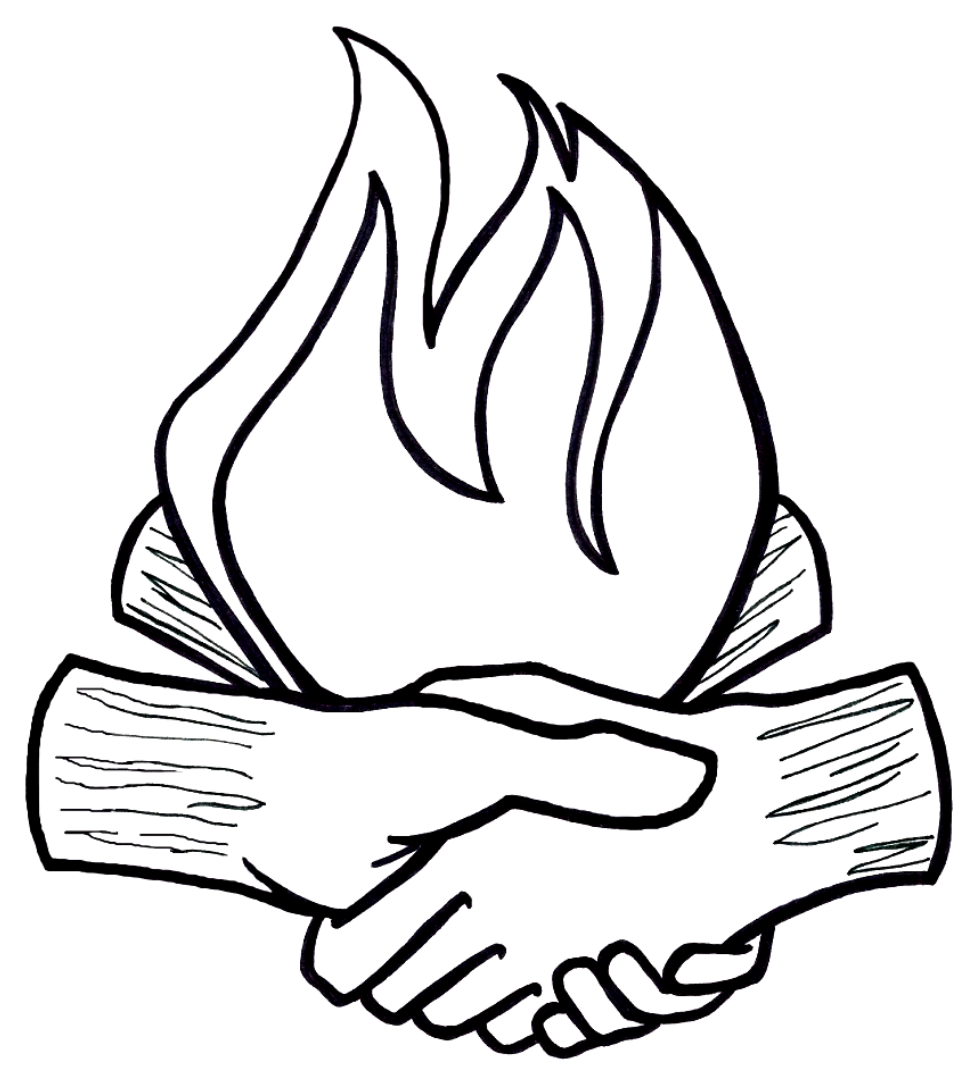

West Virginia Friends of Firewood Network: Strengthening a healthy firewood industry

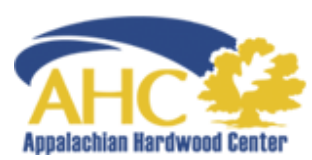


Please return the completed questionnaire in the postage-paid envelope provided to:

Liz Basham

Appalachian Hardwood Center

West Virginia University Division of Forestry \& Natural Resources

P.O. Box 6125

Morgantown, WV 26506-6125

Please contact Liz Basham at ejbasham@mix.wvu.edu or (304) 212-4535 if you have any questions.

\begin{abstract}
About this Survey
The purpose of this survey is to gain new knowledge and understanding about the West Virginia firewood industry. The intent of the survey is to interview firewood producers in order to explore the quality, quantity, and diversity of firewood production in the state. We hope you will participate in this effort as you represent a unique component of the industry in the way you gather, process, and/or distribute firewood.
\end{abstract}

This survey process is also part of an outreach effort to establish a peer-to-peer network among firewood producers- that is, a network of firewood producers. As part of this outreach, we will be hosting various educational classes throughout West Virginia on topics like chainsaw safety, tree pests and diseases, and basic business skills. If you would like to attend and want to be notified when these classes are scheduled, check the appropriate box on the enclosed survey; we will send you postcards or email reminders for these classes in the future.

Your participation is voluntary and you have the right to refrain from answering any questions. Please feel free to answer only those questions that you are comfortable answering. If you choose to participate, your answers will be kept confidential.

Thank you for your assistance with this important project!

\title{
Instructions:
}

- Either a pen or pencil can be used.

- When answering questions that require marking a box, please use an " $\mathrm{X}$ ".

- If you need to change an answer, please make sure that your old answer is either completely erased or clearly crossed out.

- All returned questionnaires will remain confidential at all times. 


\section{START SURVEY HERE}

\section{Benefits and Motivations of Firewood Production}

First we would like to ask you a few background questions about how you got into the firewood industry.

1. How many years have you been selling firewood? years

2. How did you get into the firewood business? (Please describe briefly)

3. Do you see yourself passing down your business to your children? (Check one only)
$\square$ Yes
$\square$ No
Not applicable

4. On a scale of 1 to 4 , with 1 being "Strongly Disagree" and 4 being "Strongly Agree," please rate the following statements: (Circle the number of your answer)

$\begin{array}{lcccc}\text { Statement: } & \begin{array}{c}\text { Strongly } \\ \text { Disagree }\end{array} & \begin{array}{c}\text { Somewhat } \\ \text { Disagree }\end{array} & \begin{array}{c}\text { Somewhat } \\ \text { agree }\end{array} & \begin{array}{c}\text { Strongly } \\ \text { agree }\end{array} \\ \begin{array}{l}\text { Producing firewood is beneficial to my } \\ \text { physical health. }\end{array} & \mathbf{1} & \mathbf{2} & \mathbf{3} & \mathbf{4} \\ \begin{array}{l}\text { Producing firewood is enjoyable for me. } \\ \text { I meet interesting people as a result of }\end{array} & \mathbf{1} & \mathbf{2} & \mathbf{3} & \mathbf{4} \\ \begin{array}{l}\text { selling firewood } \\ \text { I like producing firewood because the }\end{array} & \mathbf{1} & \mathbf{2} & \mathbf{3} & \mathbf{4} \\ \begin{array}{l}\text { I likive producing and selling firewood } \\ \text { because it is a good source of income. }\end{array} & \mathbf{1} & \mathbf{2} & \mathbf{3} & \mathbf{4} \\ \begin{array}{l}\text { Firewood is an environmentally friendly } \\ \text { source of energy. }\end{array} & \mathbf{1} & \mathbf{2} & \mathbf{3} & \mathbf{4}\end{array}$

5. What do you do for a living, if firewood is not your main source of income?

\section{Firewood Harvesting and Production Practices}

In this part of the questionnaire, we will be asking questions related to how and where you acquire the firewood that you sell.

We are defining raw wood as tree or log length pieces; wood that is either in live or dead standing trees or logs that are already cut down.

6. How far are you willing to travel to harvest or purchase your raw wood for firewood? miles 
7. What proportion of the firewood that you process (cut and split) and sell is from wood that you have obtained free of any fee or payment? percent $(\%)$

8. In which state does most of your firewood production take place?

9. How much wood do you get from the following sources? (Please make sure your answers add up to 100)

Source: $\%$ Harvest from own woodlot $\%$ Purchase from land clearing company $\%$ Purchase from tree service companies $\%$ From pallets $\%$ Other (Please describe the source):

\section{Source:} $\%$ Purchase from logger $\%$ Purchase from lumber mills $\%$ Harvest from State parks or forests

10. What proportion of the firewood that you process (cut and split) and sell is from wood that you have purchased as raw wood? percent $(\%)$

11. Of all the trees used to process into your firewood, how many would you say you cut down personally? (Check only one)

$\square \quad$ None
$\square \quad$ A few
$\square \quad$ Less than half
$\square \quad$ About half
$\square \quad$ More than half
$\square \quad$ Almost all/ALL

\section{Business Practices and Marketing}

In this part of the questionnaire, we will be asking you questions about your customers, the kinds of wood you sell, and how you advertise your firewood.

12. Because the West Virginia firewood industry is so diverse, we would like you to best categorize your business. (Check only one number)

Logger that sells bucked logs or firewood

Individual producer or dealer

Tree removal/care company that sells scrap wood or firewood

Saw mill that sells scrap wood or firewood

Coal or other fuel company that sells firewood

Other (please describe): 
13. To whom do you currently sell the majority of your firewood? (Enter 1 for your main customer and 2 for your second-ranking)

$\square$ Private individuals or homeowners

$\square \quad$ Public or private parks or campgrounds

$\square$ Large retailers (Walmart, Lowes, grocery store chains, etc.)

$\square$ Small retailers such as convenience stores or gas stations, farmer's markets

$\square$ Other (please describe):

14. What percentage of your customers would you say return to purchase their firewood from you for more than 2 years? percent $(\%)$

15. What proportion of your customers is located within West Virginia? percent $(\%)$

16. Do you deliver? (check one)

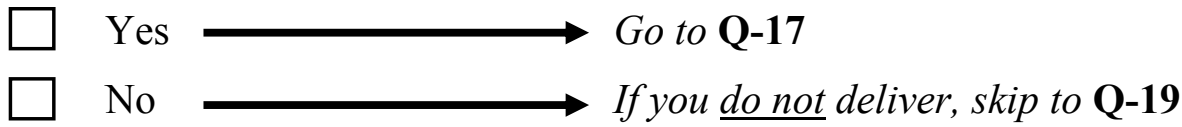

17. How many miles are you willing to drive to deliver firewood to your customers? miles

18. How do you charge for delivery? (Please include price and volume)

19. In what kinds of "units" do you sell your firewood, and what is your price per unit? (Circle all numbers that apply and provide prices)

\section{Units:}

a. Truckload

Please list the approximate bed dimensions for your largest and second largest trucks (length $\mathrm{x}$ width $\mathrm{x}$ depth):

\section{Truck 1:}

Truck 2:

b. Cord

c. Half cord

d. Face cord

e. Smaller prepackaged bundles

f. Wheelbarrow load

g. Other (please describe):
Price/unit

(ex., \$120/cord):
$\$$

$\$$

$\$$

$\$$

$\$$

$\$$

$\$$

$\$$ 
20. Using the units that you listed above, about how much firewood volume (examples: cords, truck loads, etc.) did you sell last year?

21. Do you provide a discount to customers who pick up their own firewood? (check one)

$\square$ No $\quad \square$ Yes

If yes, please explain:

22. In what size or condition do you usually sell your firewood? (Circle all numbers that apply)

Logs longer than 4 feet

Round wood (shorter than 4 feet)

Seasoned

Other (please describe):

23. How do you advertise your firewood for sale? (Check all that apply)

$\square$ Newspaper $\quad \square$ Fliers or business cards in stores/gas stations

$\square$ Word of mouth $\square$ Internet

$\square$ Yellow pages $\quad \square$ Campgrounds

$\square$ Outdoor signs

$\square$ Other (please describe):

24. What percentage of your personal individual income comes from selling firewood? $\%$

25. On a scale of 1 to 4 , with 1 being "Strongly Disagree" and 4 being "Strongly Agree," please rate the following statements:

\section{Statement:}

$\begin{array}{lccc}\text { Strongly } & \text { Slightly } & \text { Slightly } & \text { Strongly } \\ \text { disagree } & \text { disagree } & \text { agree } & \text { agree }\end{array}$

My firewood business is a hobby; I sell

the firewood that I do not use for

myself.

1

2

3

4

My firewood business generates

enough income for me to report to the

IRS.

1

2

3

4

My firewood business has a lot of

competition where I live.

1

2

3

4

26. How many years into the future do you think you will be producing firewood? years 


\section{Wood Hygiene Practices}

In this part of the questionnaire, we would like to ask a few questions about how you "sanitize" your firewood, that is, how you keep your firewood pest-free.

27. Do you season your firewood?

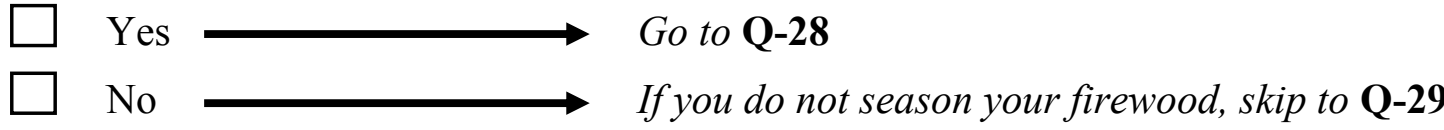

28. On average, how long do you season your firewood? $\operatorname{month}(\mathrm{s})$

29. Do you sanitize your firewood in any other way? (Check all that apply)

I do not sanitize my firewood

Kiln drying

De-barking

Heat treatment

Fumigation

Other (please describe):

\section{Best Management Practices for Firewood}

In this part of the questionnaire, we will ask you a few questions about your knowledge of firewood regulations in West Virginia.

30. What percentage of the following types of raw wood do you harvest? (Please make sure your responses add up to 100)

$\% \quad$ Easily-processed, straight, healthy trees

$\% \quad$ Fallen timber, tree tops or downed trees; windfalls

$\% \quad$ Undesirable species of trees

$\% \quad$ Diseased and/or less healthy trees; standing dead timber

$\% \quad$ Other (please describe):

31. Are you aware of any laws or regulations in the state of West Virginia limiting the movement of firewood? (Check one)

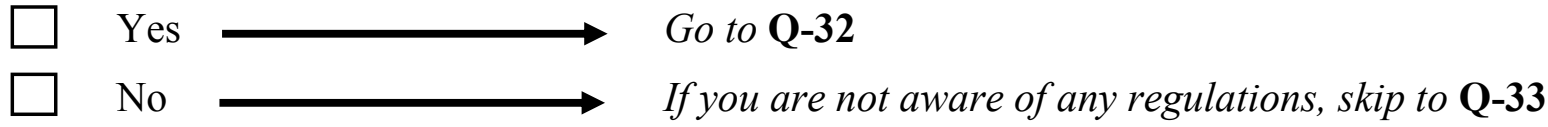

32. How do these regulations affect your business, if at all?

33. What are the main forest pests or diseases that you have heard about recently? 
34. On a scale of 1 to 5 with 1 being "Completely disagree" and 5 being "Completely agree," rate the following statements:

\section{Statement:}

$\begin{array}{ccccc}\text { Completely } & \begin{array}{c}\text { Somewhat } \\ \text { disagree }\end{array} & \begin{array}{c}\text { I don't } \\ \text { disagree }\end{array} & \begin{array}{c}\text { Somewhat } \\ \text { know }\end{array} & \begin{array}{c}\text { Completely } \\ \text { agree }\end{array}\end{array}$

Invasive species moved in firewood are threatening the health of US forests.

1

2

3

4

5

My firewood business could be affected by the health of West Virginia forests in the near future.

The success of my firewood business is directly related to having healthy forests.

The WV firewood industry can help maintain healthy forests.

1

1

1
2

2

2
3

3

3
4

5

5

35. In the neighboring states around West Virginia various voluntary "Firewood Best

Management Practices" have been adopted by firewood producers. On a scale of 1 to 4, with 1 being "Very difficult" and 4 being "Very easy," how easy would it be for you to adopt the following voluntary Best Management Practices:

\section{Firewood best management practice:}

Selling your firewood locally, within 50 miles of where it was harvested.

Providing customers with a standard description of firewood volume, such as the number of cubic feet or "cords"

Giving customers sales receipts detailing wood origin and type, and your business contact information.

Keeping records of your sales including wood origin and type, customer contact information and dates and location of sale or delivery.

De-barking and seasoning the firewood you sell for 1 year or more.

Leaving healthy trees and wildlife habitat when harvesting firewood, to promote forest regeneration and health.

Heat-treating the firewood you sell.

Obtaining a compliance agreement from the United States Department of Agriculture and sterilizing firewood according to a treatment schedule if it is to be transported into or out of a federal or state quarantine.

\section{Very Somewhat Somewhat difficult difficult easy Very easy}$$
1
$$

2

3

4

1

2

3

4

1

2

3

4

1

2

3

4

1

2

3

4

12

3

4

1

2

3

4

2

3

4 
36. In some states, firewood producers have the option of earning a "Community Firewood Dealer" certificate that lets their customers know that they sell a quality, sustainable product. Would you be willing to take part in two to three, 3-hour classes in order to obtain such certification? (Check one)

$\square$ Yes $\quad \square \quad$ No Why or why not?

37. How likely do you think your customers would be to pay more for firewood with a certified "clean" or "pest free" label? (check one)

$\square$ Highly Unlikely $\square$ Somewhat Unlikely $\square$ Somewhat Likely $\square$ Very Likely

\section{Firewood Operations Safety Practices}

Please let us know about your firewood operations safety practices.

38. How many hours per week do you spend on the following activities related to your firewood business?

$\begin{array}{lll}\text { Harvesting/cutting } & \text { hours } & \begin{array}{l}\text { Accounting, tax prep, etc. } \\ \text { Splitting }\end{array} \\ \text { Delivering/stacking } & \text { Marketing/advertising } & \text { hours }\end{array}$

Other activities (please describe): hours

39. Does anyone help you in your firewood production? (If no, skip to Q-41)
No (Skip to Q-40)
Friend(s)
Employee(s)
Family member(s)
Other (please describe):

40. What kind of safety training do you provide to these "helpers?"

41. Do you or any of these helpers ever work alone while processing firewood?

$\square$ Yes $\square$ No

42. What time of day would you say you typically harvest or cut most of your raw wood for firewood?

(Enter time and circle AM or PM)

$\mathrm{AM} / \mathrm{PM}$

43. Do you use any kind of mechanized equipment (including a chainsaw)? (Check one)

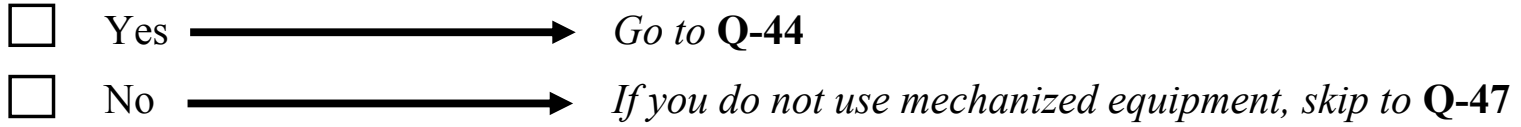


44. Which of the following mechanized equipment do you use? (Circle all that apply)

Chainsaw Log splitter Tractor Other (describe):

45. What kinds of personal protective equipment (PPE) or apparel do you wear when you use a chainsaw? (Check all that apply)

$\begin{array}{lll}\square & \text { None } \square \text { Ear muffs or plugs } & \square \text { Hardhat/helmet } \square \text { Gloves } \\ \square & \begin{array}{l}\text { Steel-toed boots } \\ \text { pants }\end{array} \\ \square & \text { Other (please describe): }\end{array}$

46. If you don't use PPE all the time when using a chainsaw or other mechanized equipment, why do you choose not to? (Check all that apply)

Not necessary (work is not dangerous)

Gear not available, or don't own any

Gear gets in the way and slows down work progress

Gear is uncomfortable because of temperature (too hot or cold)

Gear is uncomfortable because of poor fit (too large or small)

Other (please describe):

47. What is the most common injury that you experience from processing firewood? (If you have never experienced an injury, skip to Q-51)

48. In the past 12 months, how many injuries related to firewood production made you miss more than one day of work?

49. In the past 12 months, how many injuries related to firewood production needed medical treatment beyond First Aid (at urgent care, doctor's office, etc.)?

50. If you have had an injury of this type, please tell us about the most recent injury:

50a. What part of the body was affected?

50b. Briefly describe how your injury occurred (What, where and how? For example, "slipped and hit ground; lost control of chainsaw and got cut; lifting something heavy and strained back, etc."):

50c. What were you doing when this injury occurred? (Describe- examples include "climbing over a log; using a chainsaw, etc.") 


\section{Educational Needs and Interests}

Please tell us about educational topics and trainings that might be useful to firewood producers.

51. On a scale of 1 to 4 , with 1 being "Highly Unlikely" and 4 being "Very Likely," how likely are you to attend the following educational classes geared toward making your firewood business more productive and successful, or sustainable?

\section{Topic:}

$\begin{array}{cccc}\text { Highly } & \text { Somewhat } & \text { Somewhat } & \text { Very } \\ \text { Unlikely } & \text { Unlikely } & \text { Likely } & \text { Likely }\end{array}$

Marketing strategies (effective advertising and increasing sales)

Improving the health of your woodlot

Chainsaw safety practices

Pest and disease identification

Wood hygiene techniques

Personnel management

Accounting techniques

Tax preparation

$\begin{array}{llll}1 & 2 & 3 & 4 \\ 1 & 2 & 3 & 4 \\ 1 & 2 & 3 & 4 \\ 1 & 2 & 3 & 4 \\ 1 & 2 & 3 & 4 \\ 1 & 2 & 3 & 4 \\ 1 & 2 & 3 & 4 \\ 1 & 2 & 3 & 4\end{array}$

52. Are there any other outreach class topics that you would be interested in that I haven't mentioned?

$$
\text { No } \square \text { Yes (please describe): }
$$

53. How much would you be willing to pay to take a 3-hour educational class? $\$$

54. How far would you be willing to travel to attend an educational class? miles

\section{Demographic Information and Future Contact}

Please answer the following questions about yourself:

55. What is your gender? $\square$ Female $\quad \square$ Male

56. What is your age? $\square 18$ - 30 yrs $\square 40$ - $50 \quad \square 60$ - 70

$\square 30-40 \quad \square 50-60 \quad \square 70+$

57. What is your current occupation?

58. I reside in: County State 
59. What is the highest level of education you have completed? (Check only one)

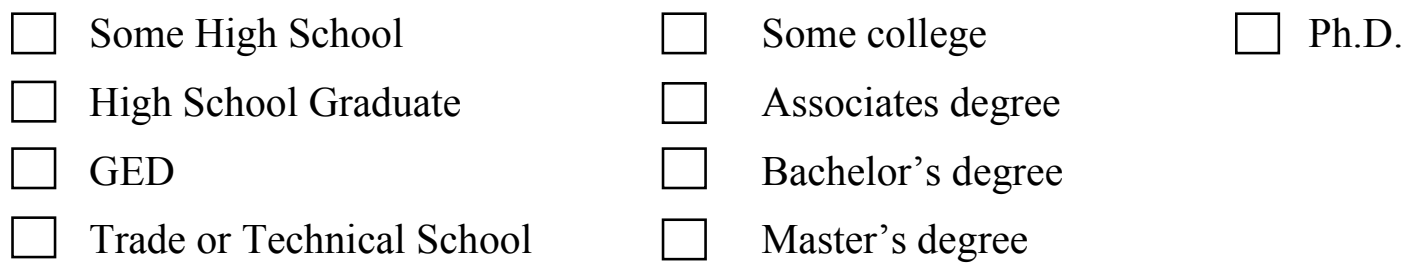

60. What is your average yearly income? (Check only one)
$\square$ Less than 15,000
$\square \quad \$ 45,001-\$ 60,000$
$\$ 15,001-\$ 30,000$
$\$ 60,001-\$ 75,000$
$\$ 30,001-\$ 45,000$
$\square \quad \$ 75,001-\$ 90,000$

61. Would you be interested in becoming part of a free peer-to-peer firewood dealers' network that could provide you with educational opportunities, marketing strategies and other resources?

$\square$ Yes $\square$ No

62. Do you have the contact information for any other firewood dealers in the area that we may interview to further enrich our research project results?
$\square$ No
$\square \quad$ Yes
If yes, please provide as much contact information as possible (name and city, telephone, or email):

63. We post educational workshops for firewood producers on our free WV Friends of Firewood Network website. Would you like us to send you an invitation via email for so you can access this website?
Yes please. Email:
No thanks
$\square \quad$ I am already a "member"

64. Please check all that apply to you:

$\square \quad$ I would like a copy of the summary of results from this survey.

$\square \quad$ I would like to receive postcard notifications of educational classes happening in my area pertaining to improving my business, chainsaw safety, pest identification and wood hygiene.

$\square \quad$ Do not send me any results, notifications or invitations.

\section{Thank you for your help with this survey!}




\section{APPENDIX G: Mail Questionnaire Reminder Postcard}

\section{Reminder About Important Survey}

\section{Friends of Firewood Survey}

Dear Firewood Producer

Two weeks ago we mailed a survey designed to collect information about the West Virginia firewood industry. This is part of a research project that is being conducted by West Virginia University. WVU's Institutional Review Board acknowledgement of this study is on file.

If you have already completed and returned the survey, please accept our sincere thanks. If not, please take a few minutes to do so today.

Your insight will contribute to a more productive firewood industry while preserving the health of West Virginia woodlands.

If y ou did not receive a survey or have misplaced it, please call us and we will mail another one immediately. Thank you in advance for your participation.

Dave McGill

Professor of Forestry (304) 293-5930

dmcgill@wvu.edu

\section{Liz Basham} Graduate Research Assistant (304) 212-4535 ejbasham(amix.wvu.edu

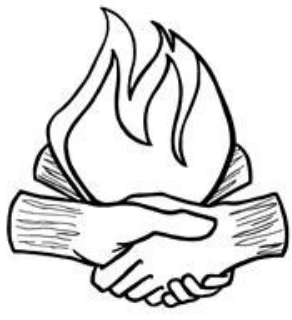

W. WestVirginiaUniversity 


\begin{abstract}
APPENDIX H: Additional Work
Possible Firewood Best Management Practices for West Virginia Producers

These firewood BMPs are based on research from various state extension websites, peerreviewed journal articles and federal recommendations (Table 41). Some of the practices may not be appropriate for smaller enterprises that sell within county and/or state lines, but this list is meant to cover basic practices of an honest, reliable and environmentally aware firewood producer.
\end{abstract}


Table 41. A compilation of possible best management practices for West Virginia firewood producers.

Firewood Best Management Practice

Wood Hygiene/Forest Health

Selling firewood locally: not transporting it more than 50 miles from its source

De-barking and seasoning firewood $1+$ years $(\mathrm{MC}<20 \%)$

Practicing logging BMPs when performing firewood harvesting

Practicing sustainable silviculture and leaving wildlife habitat when harvesting firewood, to promote forest health

Heat-treating firewood before transporting it out of an infested county or state

Obtaining a compliance agreement from the USDA which details specific protocols regarding infested firewood

Learning about invasive insects and disease transported by firewood and associated regulations and quarantines

Supplying clean and uncontaminated wood

\section{Business Practices/Marketing}

Providing customers with a standard description of firewood volume, such as cubic feet, or cords

Labeling firewood and providing customers with sales receipts detailing wood origin and species, volumes, pricing and business contact information

Keeping records of sales including wood origin and species, volumes harvested and sold, customer contact information, and dates and locations of sales and/or deliveries

Registering the firewood business and/or becoming licensed with the county and/or state

Becoming certified by the USDA or state organizations

Providing good customer service, being reliable and flexible with delivery

\section{Safety/PPE Use}

Learning and practicing proper chainsaw safety

Wearing all appropriate, well-fitting PPE at all times, and replacing it regularly

Working when alert and rested and not under the influence of any intoxicant

Cleaning and regularly maintaining work area and mechanical equipment; replacing the latter when necessary

Not working alone; having someone at least within shouting distance

Have an escape route when felling trees and use directional felling to prevent damage to residual trees

Lifting with the legs and not the back

\section{Country, State, Province or Organization Where}

\section{Practiced}

Continental U.S., National Firewood Task Force (NFTF), National Firewood Association (NFA), USDA Forest Service, Canada \& Europe;

CA, TN, KY, WI, CO, MN, NC, AK, NFTF, NFA, Canada, Scotland, UK (Northern Wood Heat)

NY, IL, OK, USDA Forest Service

NY, IL, OK, MO, Canada, Model Forest of Newfoundland and Labrador, Firewood Association of Australia (FAA)

VT, CA, OH, TN, KY, WI, CO, NC

$\mathrm{KY}, \mathrm{CO}, \mathrm{NFTF}$

VT, WI, NC, NFTF, NFA

UK

Most state offices of Weights and Measures, NFA, FAA

VA, OH, NY, PA, MD, CO, MN, NH, NFTF, FAA, Scotland, UK

NFTF

$\mathrm{MD}, \mathrm{PA}, \mathrm{NY}$

WI

NFA, Scotland, FAA, UK

Most state extensions, OSHA

Most state extensions, USDA Forest Service, OSHA

NY, USDA Forest Service

NY, MN, OH, OK, SC, USDA Forest Service, Model Forest of Newfoundland and Labrador

VA, USDA Forest Service

VA, NY, IL, OK, Model Forest of Newfoundland and Labrador VA, IN 


\section{A Diagram of the West Virginia Firewood Industry Supply Chain}

The firewood supply chain in West Virginia is similar to that seen in other states: there are many smaller producers and a few larger-volume producers, typically operating in an informal market; firewood can come from personal woodlots, sawmills, logging operations and tree service companies; most of this firewood makes it to homeowners, where its end use is home heating, but some can make it to campgrounds and small retailers. The visual display that the author developed (Figure 23) is based on the results from this project and is loosely adapted from a firewood pathway diagram developed by Runberg in his 2011 Oregon State University thesis (2011).

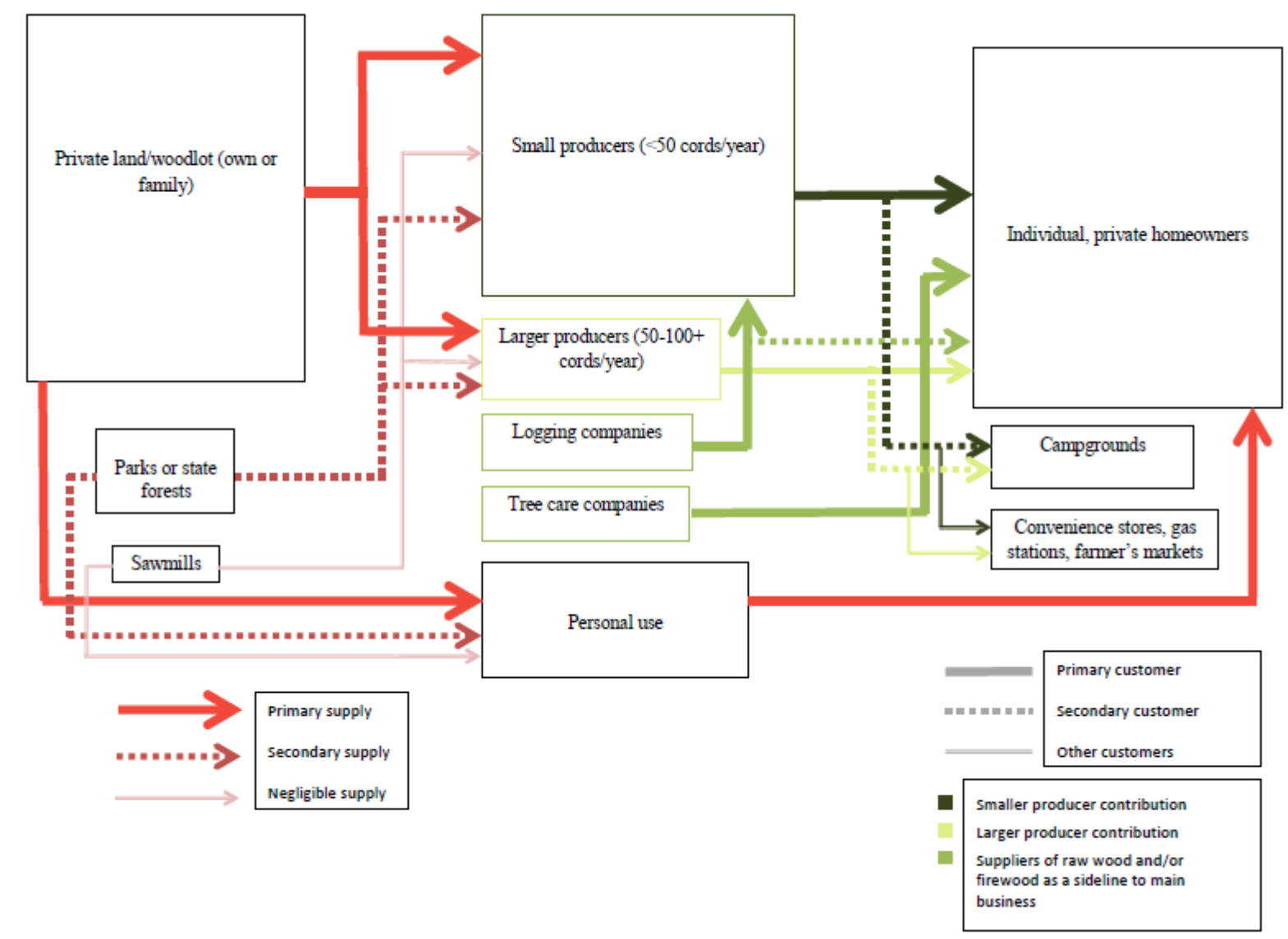

Figure 23. A visual model of the firewood supply chain in West Virginia based on results from this two-part survey. 